\title{
Dietary proteins : their effect on insulin and glucagons in relation to body weight management
}

Citation for published version (APA):

Claessens, M. (2008). Dietary proteins : their effect on insulin and glucagons in relation to body weight management. [Doctoral Thesis, Maastricht University]. Universitaire Pers Maastricht. https://doi.org/10.26481/dis.20080116mc

Document status and date:

Published: 01/01/2008

DOI:

10.26481/dis.20080116mc

Document Version:

Publisher's PDF, also known as Version of record

\section{Please check the document version of this publication:}

- A submitted manuscript is the version of the article upon submission and before peer-review. There can be important differences between the submitted version and the official published version of record.

People interested in the research are advised to contact the author for the final version of the publication, or visit the DOI to the publisher's website.

- The final author version and the galley proof are versions of the publication after peer review.

- The final published version features the final layout of the paper including the volume, issue and page numbers.

Link to publication

\footnotetext{
General rights rights.

- You may freely distribute the URL identifying the publication in the public portal. please follow below link for the End User Agreement:

www.umlib.nl/taverne-license

Take down policy

If you believe that this document breaches copyright please contact us at:

repository@maastrichtuniversity.nl

providing details and we will investigate your claim.
}

Copyright and moral rights for the publications made accessible in the public portal are retained by the authors and/or other copyright owners and it is a condition of accessing publications that users recognise and abide by the legal requirements associated with these

- Users may download and print one copy of any publication from the public portal for the purpose of private study or research.

- You may not further distribute the material or use it for any profit-making activity or commercial gain

If the publication is distributed under the terms of Article $25 \mathrm{fa}$ of the Dutch Copyright Act, indicated by the "Taverne" license above, 


\section{Dietary proteins:}

Their effects on insulin and glucagon in relation to

body weight management 


\section{nututim}

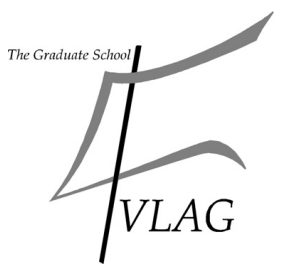

The studies presented in this thesis were performed at the Nutrition and Toxicology Research Institute Maastrich (NUTRIM), which participates in the Graduate School VLAG (Food Technology, Argobiotechnology, Nutrition and Health Sciences), accredited by the Royal Netherlands Academy of Art and Sciences

Cover design: Suzy Claessens and Jonas Maebe

Layout: Mandy and Francis Claessens

Printed by: Datawyse, Universitaire Pers Maastricht

ISBN 978-90-5278-689-6

(C) Mandy Claessens 2007 


\title{
Dietary proteins:
}

\section{Their effects on insulin and glucagon in relation to}

\author{
body weight management
}

\section{PROEFSCHRIFT}

Ter verkrijging van de graad van doctor aan de Universiteit Maastricht, op gezag van de Rector Magnificus,

Prof. mr. G.P.M.F. Mols

volgens het besluit van het College van Decanen,

in het openbaar te verdedigen

op woensdag 16 januari 2008 om 12:00 uur

door

Mandy Claessens

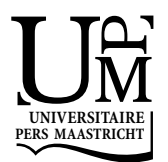




\section{Promotors:}

Prof. dr. ir. W.H.M. Saris

Prof. dr. M.A. van Baak

\section{Beoordelingscommissie:}

Prof. dr. R.P. Mensink (voorzitter)

Prof. dr. R-J.M. Brummer

Dr. H.F.J. Hendriks (TNO Voeding, Zeist)

Dr. I.J.C van Loon

Prof. dr. D. Tomé (INRA914, Paris, France)

The studies described in this thesis were supported by a grant from Kerry Bio-Science.

Financial support by Kerry Bio-Science for the publication of this thesis is gratefully acknowledged. 


\section{Contents}

\section{Chapter 1}

General introduction

\section{Chapter 2}

The effect of different protein hydrolysate/carbohydrate mixtures on postprandial glucagon and insulin responses in healthy subjects

\section{Chapter 3}

Glucagon and insulin responses after ingestion of different amounts of intact and hydrolysed proteins

\section{Chapter 4}

The thermogenic and metabolic effect of protein hydrolysate with or without a carbohydrate load in healthy male subjects

\section{Chapter 5}

A protein- versus carbohydrate-enriched ad libitum low-fat diet improves weight control and cardiovascular risk factors in overweight and obese subjects after weight loss

\section{Chapter 6}

The influence of habitual diet on responses to a high-protein meal

\section{Chapter 7}

General discussion

Summary

Samenvatting

Dankwoord 

Chapter 1

General introduction 


\section{High-protein diets and body weight management}

The rising prevalence of overweight and obesity (1) and the associated increasing risk for e.g. type 2 diabetes and cardiovascular diseases (2-4), is a growing health problem. Recently energy restricted, high-protein diets have been found to improve insulin sensitivity, lipid profiles (5-9) and, in some studies, body weight loss more than low-fat, high-carbohydrate diets (10-14). Also after weight loss additional protein intake was found to reduce weight regain $(15,16)$. This beneficial effect of high-protein diets on weight loss and weight maintenance has been attributed to a higher energy cost of protein metabolism and storage as compared to carbohydrate or fat metabolism and storage $(15,17-20)$ and a higher satiating effect of proteins $(12,17,18,21,22)$. These effects could be related to the insulin-stimulating effect of dietary proteins that has been described in both healthy (23-27) and diabetic subjects $(28,29)$. As pointed out in a review by Tremblay and colleagues, changes in plasma insulin concentrations are positively associated with changes in resting energy expenditure (30). Therefore, after losing weight, overweight subjects might have difficulties to remain weight stable because of an improved metabolic status (30). Next to their insulin stimulating effect, proteins are also found to induce glucagon stimulation. Glucagon has generally been found to be a counter-regulatory hormone of insulin. In addition, with increased plasma glucagon levels a reduced meal size was observed (31). Therefore, elevated glucagon levels might be beneficial regarding weight maintenance. Although insulin secretion and how it is affected by macronutrient composition, obesity and weight loss has been studied extensively this is only poorly studied for glucagon. Therefore, the remainder of this introduction will focus on glucagon and the interaction between insulin and glucagon.

\section{Glucagon as counter-regulatory hormone of insulin}

Glucagon is a peptide hormone composed of 29 amino acids with a molecular weight of $3485 \mathrm{Da}$. Glucagon is derived from a larger precursor, proglucagon, which is processed to oxyntomodulin, glycentin, GLP-1 and GLP-2 in the ileum and to glucagon in the pancreatic alpha $(\alpha)$ cells. The most studied function of glucagon is its role in glycemic control. Glucagon is secreted when circulating glucose is low, i.e. $3.8 \mathrm{mmol} / \mathrm{L}(32)$. Hypoglycemia can induce glucagon secretion by three different mechanisms. First, hypoglycemia might have a direct effect on pancreatic $\alpha$-cells resulting in glucagon secretion (33). Furthermore, hypoglycemia inhibits secretion of e.g. insulin and gamma aminobutyric acid from $\beta$-cells, molecules that normally inhibit $\alpha$-cell induced 
glucagon secretion and in this way removes the tonic inhibitory restraint on $\alpha$-cells (33). A third mechanism through which hypoglycemia induces glucagon secretion is via the autonomic nervous system. There are three major autonomic inputs to $\alpha$-cells: sympathetic nerves, parasympathetic nerves and epinephrine secretion from the adrenal medulla (33).

Upon binding to its receptor, glucagon will activate a cascade resulting in increased glycogen breakdown (glycogenolysis) in the liver, which results in increasing plasma glucose concentrations $(34,35)$. In addition, glucagon inhibits glycogen synthesis (glycogenesis) by inhibiting the glycogen synthase activity in the liver. Finally, glucagon can increase circulating glucose levels by reducing liver glycolysis. In this regard, glucagon inhibits phosphofructokinase-1 activity, which converts fructose 6phosphate into fructose-1,6-biphosphate, a rate-limiting step in glycolysis (34). Furthermore, glucagon increases gluconeogenesis, which is the generation of glucose from non-sugar carbon substrates like pyruvate, lactate, glycerol and amino acids by upregulating liver glucose-6-phosphatase $(34,35)$.

\section{Glucagon regulation}

Pancreatic $\alpha$-cells are found to express the insulin receptor at similar levels as hepatic cells, suggesting that also $\alpha$-cells are important sites for insulin action (36). This idea is supported by the finding that pulsatile insulin secretion suppresses glucagon secretion by activating ATP-dependent potassium channels on $\alpha$-cells, thus preventing calcium influx and its associated glucagon release (36-39). In type 2 diabetic patients, the lack of this inhibitory effect of insulin on glucagon secretion could cause hyperglycemia (40). Indeed, in type 2 diabetic patients hyperglucagonemia has been reported (41). All these findings fit with the idea that when plasma glucose rises, insulin secretion is activated while glucagon secretion is suppressed so that glucose can be taken up rapidly, mainly by muscle cells. When dietary proteins are ingested, with or without carbohydrate coingestion, both insulin and glucagon are secreted $(25,27,42,43)$. Although this might seem contradictory, Pipeleers and colleagues demonstrated that the amino acid-induced glucagon secretion from isolated pancreatic $\alpha$-cells is not or only partly inhibited by increased insulin levels (44). 


\section{Glucagon and lipolysis}

Glucagon is shown to have lipolytic effects in adipose tissue of several species (45-47), although in humans conflicting results have been reported (48-51). The presence of specific glucagon receptors in solubilised membranes of human adipocytes has been demonstrated (52). In addition to low affinity binding sites, human adipocytes were also found to contain high affinity binding sites (52). Therefore, theoretically glucagon might also be lipolytic upon receptor binding in human adipocytes. Experiments in which human adipocytes were isolated and stimulated in vitro with physiological concentrations of glucagon indeed reported a lipolytic effect $(51,53)$. Also in vivo glucagon infusion experiments revealed a positive effect of glucagon on lipolysis (50, 54). Studies measuring the lipolytic effect of glucagon by means of microdialysis in abdominal adipose tissue, on the other hand, could not find any effect of glucagon (48, 49). As Miles and Jensen (1993) reported, it is very difficult to perform decent measurements of glucagon-induced adipose tissue lipolysis (45). The reason for this is that in most of these studies $(48,50,54)$ endogenous insulin, growth hormone and glucagon secretion are suppressed by somatostatin co-infusion. Although pancreatic hormone secretion is, in this way, strongly inhibited, this blockade is relative and breakthrough insulin secretion might occur. Jensen and colleagues (1989) showed that an increase of plasma insulin of only $1.0 \mu \mathrm{U} / \mathrm{mL}( \pm 7 \mathrm{pmol} / \mathrm{L})$ can induce a reduction of free fatty acid appearance of approximately $20 \%$ and this effect may mask a glucagoninduced stimulation of lipolysis (55). On the other hand, in the study of Bertin and colleagues (49) local infusion of glucagon into adipose tissue without somatostatin did not result in changes in interstitial glycerol concentration, a marker of lipolysis. Taken together, it remains uncertain whether glucagon has a role in activating lipolysis in humans.

\section{Glucagon in relation to substrate oxidation and energy expenditure}

As pointed out above, one of the effects of glucagon is the induction of gluconeogenesis. This process of de novo glucose synthesis is estimated to account for between 5 and $8 \%$ of sleeping metabolic rate (SMR) in humans (56). When glucose is synthesised from glycerol 2 ATP is needed to generate 1 mol glucose, while in case of pyruvate, alanine, glutamine and lactate 6 ATP is used for the conversion into glucose $(35,56)$. Flakoll and colleagues (1994) reported that glucagon has a positive effect on the extraction and uptake of amino acids by the liver where they can be used as substrate for gluconeogenesis (57). Therefore, when high amounts of amino acids are present in the circulation it is likely that gluconeogenesis is stimulated and amino acids 
are converted into glucose, which has a relatively high energy cost. Furthermore, even when circulating amino acids are low, glucagon infusion has been found to enhance resting metabolic rate in human subjects $(58,59)$. In these studies it was suggested that, next to the effect on gluconeogenesis, glucagon inhibits protein synthesis and stimulates urea synthesis, protein oxidation and, in the absence of circulating amino acids, protein degradation, suggesting that glucagon has a catabolic effect on protein metabolism (5861 ). While protein synthesis is known to have a high energy cost (15-18\% of SMR) the net energy costs of protein degradation are not clear but are likely to be lower than the energy costs for protein synthesis (56). Also the cost of urea synthesis is low as compared to the cost of protein synthesis. Nevertheless, protein degradation may also make a small but significant contribution to SMR in humans ( $\pm 2 \%$ of SMR) (56). When, both glucagon and insulin levels are enhanced, which is the case after protein consumption, the negative effect of glucagon on protein synthesis is partly reversed (61). Therefore, the increased energy expenditure often found after high-protein meals $(19,21,62-65)$ or during high-protein diets $(15,16,18,20,66)$ can, at least partly, be caused by both the insulin- and glucagon-stimulating effect of proteins resulting in stimulation of gluconeogenesis, urea synthesis and protein synthesis, all reactions with relatively high energy costs.

\section{The insulin:glucagon ratio and lipid metabolism}

Insulin and glucagon are both important mediators in cholesterol metabolism. Both hormones influence the expression level of sterol regulatory element binding proteins (SREBPs). There are three SREBP isoforms: SREBP-1a, -1c and -2. SREBP-1a and -1c are involved in fatty acid and triglyceride biosynthesis while SREBP-2 is mainly involved in cholesterol uptake and biosynthesis (67). It is hypothesised that insulin stimulates SREBP-1c expression and in this way promotes fatty acid and triglyceride synthesis. Increased triglyceride levels will induce liver cholesterol synthesis and therefore, insulin can indirectly stimulate cholesterol synthesis (67). Glucagon, on the other hand, is thought to counteract insulin activity by repressing SREBP-1c expression through a cAMP-dependent mechanism as indicated in the figure below (Figure 1.1) $(67,68)$. Indeed, when rats were fed a protein diet with low insulin:glucagon ratio, this resulted in reduced serum cholesterol levels (69). Similarly, in humans the hypercholesterolemic effect of casein has been associated with an elevated insulin:glucagon ratio while the hypocholesterolemic effect of soy protein was found to be associated with a reduced ratio $(70,71)$. Although soy isoflavones are found to 
Chapter 1

induce SREBP-2 transcription and therefore cholesterol clearance, to our knowledge, it is not known how SREBP-2 is related to insulin and glucagon levels is.

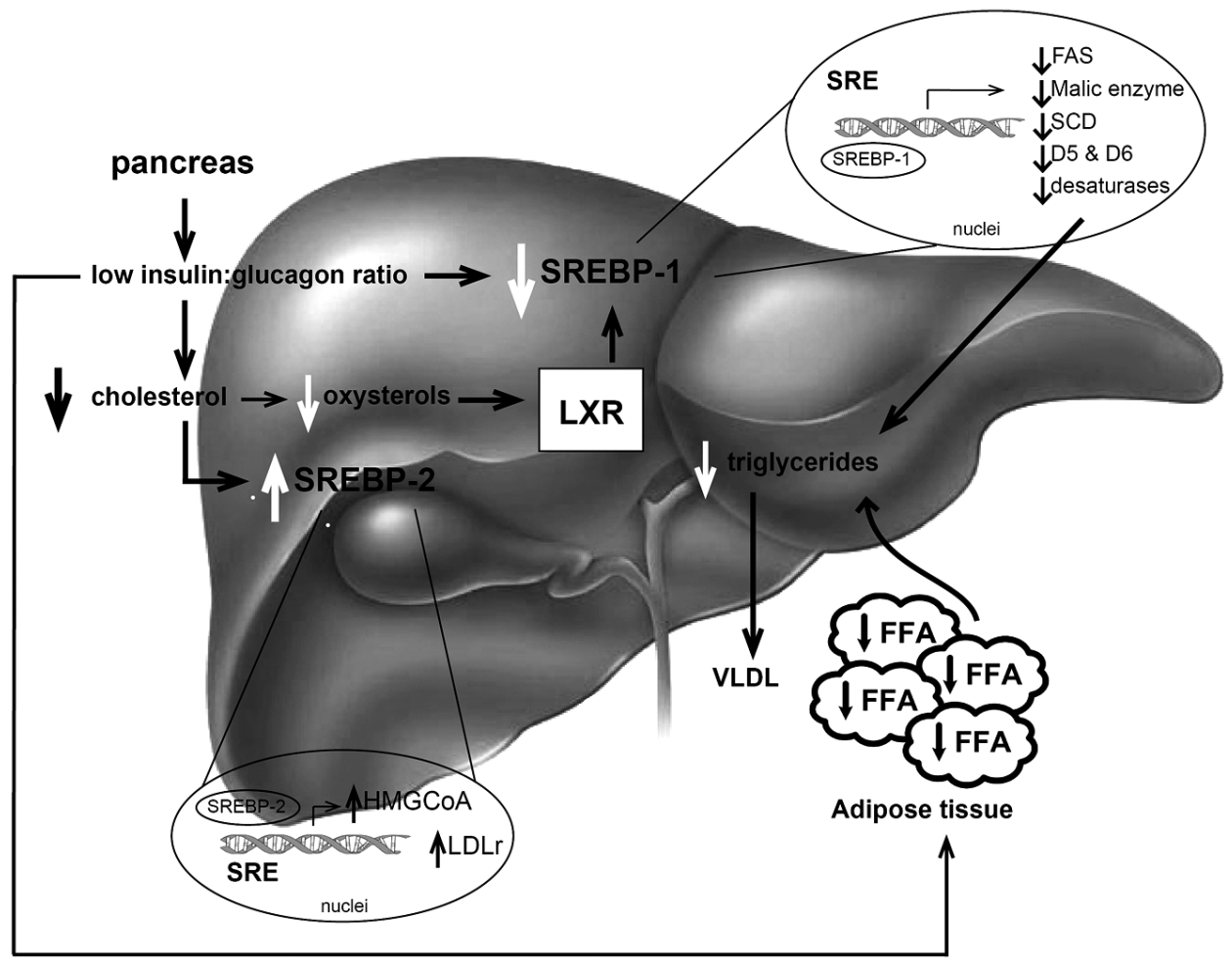

Figure 1.1 Effect of the insulin:glucagon ratio on lipid and cholesterol metabolism 


\section{Manipulation of the insulin:glucagon ratio by dietary protein}

Vegetable protein is associated with a lower insulin:glucagon ratio than animal protein (69-71). This different effect of proteins on the insulin:glucagon ratio is suggested to be due to different amino acid compositions. Generally, plant proteins have higher absolute amounts of arginine, glycine and alanine, which are associated with higher glucagon levels (72). Animal proteins have higher lysine concentrations. Lysine is thought to stimulate insulin secretion (71). A study performed by Calbet and MacLean (2002) reported, on the other hand, that the phenylalanine, arginine and glutamine contents of a protein drink were most closely associated with plasma insulin, while the methionine and tyrosin contents were most closely associated with plasma glucagon (27). Furthermore, when studying increasing doses of intact protein, Spiller and colleagues did not find an effect of protein dose on insulin secretion (73), while Kabadi reported that increasing amounts of amino acid mixtures induced increasing insulin responses an effect that was less clear for glucagon (42). Therefore, it remains unclear which amino acids are most insulin- or glucagon-stimulating and whether it is best to influence the insulin:glucagon ratio by focussing on changing plasma insulin or plasma glucagon concentrations. 


\section{Outline of this thesis}

The research presented in this thesis was conducted in order to answer the following main research questions:

1. Can the insulin and glucagon response and insulin:glucagon ratio be influenced by protein source, protein load and/or the structure of the protein?

2. Does the insulin:glucagon ratio affect energy expenditure and substrate oxidation?

3. Is the effect of high-protein diets on body weight management related to proteininduced insulin or glucagon secretion?

4. Is the effect of high-protein diets on risk factors for cardiovascular disease associated with changes in insulin or glucagon secretion?

To answer the first research question we investigated the effect of 6 different protein hydrolysate/carbohydrate mixtures and compared their insulin and glucagon stimulating effects with the effect of carbohydrates alone as described in Chapter 2. In addition, we studied the effect of 3 different concentrations of protein hydrolysates and their intact form without carbohydrate co-ingestion. This was done for 2 protein sources, soy and whey protein, to see whether the effect was similar for a vegetable and animal protein source. This study is described in Chapter 3.

In order to answer our second question, we performed 2 studies, which are dealt with in Chapter 4 and 6. In Chapter 4 we studied the effect of a single protein hydrolysate load, a single carbohydrate load and a protein hydrolysate load with a carbohydrate preor afterload on metabolic responses and diet-induced thermogenesis. In Chapter 6 we studied the postprandial effect of a high-protein mixed meal in overweight and obese subjects after 12 weeks of high-carbohydrate or high-protein weight maintenance.

We tried to solve our third and fourth research question by conducting a long-term study, discussed in Chapter 5, in which overweight and obese subjects first lost weight through a Very Low Calorie Diet, which was followed by a high-carbohydrate or highprotein weight maintenance period. During this study anthropometric measures were done and blood samples were taken for metabolic, hormonal and blood lipid measurements.

Finally, Chapter 7 puts the results of the above-described studies in a broader context. The answers that were obtained to the research questions indicated above and their practical relevance will be discussed. 


\section{References}

1. WHO (2000) Obesty: Preventing and managing the global epidemic, Geneva.

2. Grundy, S. M. (2004) Obesity, metabolic syndrome, and cardiovascular disease. J Clin Endocrinol Metab 89: 2595-2600.

3. What is the contribution of obesity to the metabolic syndrome? (2004) Endocrinol Metab Clin North Am 33: 267-282, table of contents.

4. Misra, A. \& Vikram, N. K. (2003) Clinical and pathophysiological consequences of abdominal adiposity and abdominal adipose tissue depots. Nutrition 19: 457-466.

5. Eisenstein, J., Roberts, S. B., Dallal, G. \& Saltzman, E. (2002) High-protein weight-loss diets: are they safe and do they work? A review of the experimental and epidemiologic data. Nutr Rev 60: 189-200.

6. Johnston, C. S., Tjonn, S. L. \& Swan, P. D. (2004) High-protein, low-fat diets are effective for weight loss and favorably alter biomarkers in healthy adults. J Nutr 134: 586-591.

7. Farnsworth, E., Luscombe, N. D., Noakes, M., Wittert, G., Argyiou, E. \& Clifton, P. M. (2003) Effect of a high-protein, energy-restricted diet on body composition, glycemic control, and lipid concentrations in overweight and obese hyperinsulinemic men and women. Am J Clin Nutr 78: 31-39.

8. Luscombe-Marsh, N. D., Noakes, M., Wittert, G. A., Keogh, J. B., Foster, P. \& Clifton, P. M. (2005) Carbohydrate-restricted diets high in either monounsaturated fat or protein are equally effective at promoting fat loss and improving blood lipids. Am J Clin Nutr 81: 762-772.

9. Noakes, M., Keogh, J. B., Foster, P. R. \& Clifton, P. M. (2005) Effect of an energy-restricted, highprotein, low-fat diet relative to a conventional high-carbohydrate, low-fat diet on weight loss, body composition, nutritional status, and markers of cardiovascular health in obese women. Am J Clin Nutr 81: 1298-1306.

10. Baba, N. H., Sawaya, S., Torbay, N., Habbal, Z., Azar, S. \& Hashim, S. A. (1999) High protein vs high carbohydrate hypoenergetic diet for the treatment of obese hyperinsulinemic subjects. Int J Obes Relat Metab Disord 23: 1202-1206.

11. Deibert, P., Konig, D., Schmidt-Trucksaess, A., Zaenker, K. S., Frey, I., Landmann, U. \& Berg, A. (2004) Weight loss without losing muscle mass in pre-obese and obese subjects induced by a high-soyprotein diet. Int J Obes Relat Metab Disord 28: 1349-1352.

12. Weigle, D. S., Breen, P. A., Matthys, C. C., Callahan, H. S., Meeuws, K. E., Burden, V. R. \& Purnell, J. Q. (2005) A high-protein diet induces sustained reductions in appetite, ad libitum caloric intake, and body weight despite compensatory changes in diurnal plasma leptin and ghrelin concentrations. Am J Clin Nutr 82: 41-48.

13. Skov, A. R., Toubro, S., Ronn, B., Holm, L. \& Astrup, A. (1999) Randomized trial on protein vs carbohydrate in ad libitum fat reduced diet for the treatment of obesity. Int J Obes Relat Metab Disord 23: 528-536.

14. Layman, D. K., Boileau, R. A., Erickson, D. J., Painter, J. E., Shiue, H., Sather, C. \& Christou, D. D. (2003) A reduced ratio of dietary carbohydrate to protein improves body composition and blood lipid profiles during weight loss in adult women. J Nutr 133: 411-417.

15. Westerterp-Plantenga, M. S., Lejeune, M. P., Nijs, I., van Ooijen, M. \& Kovacs, E. M. (2004) High protein intake sustains weight maintenance after body weight loss in humans. Int J Obes Relat Metab Disord 28: 57-64.

16. Lejeune, M. P., Kovacs, E. M. \& Westerterp-Plantenga, M. S. (2005) Additional protein intake limits weight regain after weight loss in humans. Br J Nutr 93: 281-289.

17. Westerterp, K. R., Wilson, S. A. \& Rolland, V. (1999) Diet induced thermogenesis measured over $24 \mathrm{~h}$ in a respiration chamber: effect of diet composition. Int J Obes Relat Metab Disord 23: 287-292. 
18. Lejeune, M. P., Westerterp, K. R., Adam, T. C., Luscombe-Marsh, N. D. \& Westerterp-Plantenga, M. S. (2006) Ghrelin and glucagon-like peptide 1 concentrations, 24-h satiety, and energy and substrate metabolism during a high-protein diet and measured in a respiration chamber. Am J Clin Nutr 83: 89-94.

19. Raben, A., Agerholm-Larsen, L., Flint, A., Holst, J. J. \& Astrup, A. (2003) Meals with similar energy densities but rich in protein, fat, carbohydrate, or alcohol have different effects on energy expenditure and substrate metabolism but not on appetite and energy intake. Am J Clin Nutr 77: 91-100.

20. Johnston, C. S., Day, C. S. \& Swan, P. D. (2002) Postprandial thermogenesis is increased $100 \%$ on a high-protein, low-fat diet versus a high-carbohydrate, low-fat diet in healthy, young women. J Am Coll Nutr 21: 55-61.

21. Crovetti, R., Porrini, M., Santangelo, A. \& Testolin, G. (1998) The influence of thermic effect of food on satiety. Eur J Clin Nutr 52: 482-488.

22. Barkeling, B., Rossner, S. \& Bjorvell, H. (1990) Effects of a high-protein meal (meat) and a highcarbohydrate meal (vegetarian) on satiety measured by automated computerized monitoring of subsequent food intake, motivation to eat and food preferences. Int J Obes 14: 743-751.

23. van Loon, L. J., Saris, W. H., Verhagen, H. \& Wagenmakers, A. J. (2000) Plasma insulin responses after ingestion of different amino acid or protein mixtures with carbohydrate. Am J Clin Nutr 72: 96-105.

24. Westphal, S. A., Gannon, M. C. \& Nuttall, F. Q. (1990) Metabolic response to glucose ingested with various amounts of protein. Am J Clin Nutr 52: 267-272.

25. Krezowski, P. A., Nuttall, F. Q., Gannon, M. C. \& Bartosh, N. H. (1986) The effect of protein ingestion on the metabolic response to oral glucose in normal individuals. Am J Clin Nutr 44: 847-856.

26. Dangin, M., Boirie, Y., Garcia-Rodenas, C., Gachon, P., Fauquant, J., Callier, P., Ballevre, O. \& Beaufrere, B. (2001) The digestion rate of protein is an independent regulating factor of postprandial protein retention. Am J Physiol Endocrinol Metab 280: E340-348.

27. Calbet, J. A. \& MacLean, D. A. (2002) Plasma glucagon and insulin responses depend on the rate of appearance of amino acids after ingestion of different protein solutions in humans. J Nutr 132: 21742182.

28. Manders, R. J., Wagenmakers, A. J., Koopman, R., Zorenc, A. H., Menheere, P. P., Schaper, N. C., Saris, W. H. \& van Loon, L. J. (2005) Co-ingestion of a protein hydrolysate and amino acid mixture with carbohydrate improves plasma glucose disposal in patients with type 2 diabetes. Am J Clin Nutr 82: 76-83.

29. Manders, R. J., Koopman, R., Sluijsmans, W. E., van den Berg, R., Verbeek, K., Saris, W. H., Wagenmakers, A. J. \& van Loon, L. J. (2006) Co-ingestion of a protein hydrolysate with or without additional leucine effectively reduces postprandial blood glucose excursions in Type 2 diabetic men. $\mathrm{J}$ Nutr 136: 1294-1299.

30. Tremblay, A., Boule, N., Doucet, E. \& Woods, S. C. (2005) Is the insulin resistance syndrome the price to be paid to achieve body weight stability? Int J Obes (Lond) 29: 1295-1298.

31. Woods, S. C., Lutz, T. A., Geary, N. \& Langhans, W. (2006) Pancreatic signals controlling food intake; insulin, glucagon and amylin. Philos Trans R Soc Lond B Biol Sci 361: 1219-1235.

32. Schwartz, N. S., Clutter, W. E., Shah, S. D. \& Cryer, P. E. (1987) Glycemic thresholds for activation of glucose counterregulatory systems are higher than the threshold for symptoms. J Clin Invest 79: 777 781 .

33. Taborsky, G. J., Jr., Ahren, B. \& Havel, P. J. (1998) Autonomic mediation of glucagon secretion during hypoglycemia: implications for impaired alpha-cell responses in type 1 diabetes. Diabetes 47: 995-1005.

34. Jiang, G. \& Zhang, B. B. (2003) Glucagon and regulation of glucose metabolism. Am J Physiol Endocrinol Metab 284: E671-678.

35. Stryer, L. (1997) Biochemistry, 4th ed. W.H. Freeman and Company, New York. 
36. Franklin, I., Gromada, J., Gjinovci, A., Theander, S. \& Wollheim, C. B. (2005) Beta-cell secretory products activate alpha-cell ATP-dependent potassium channels to inhibit glucagon release. Diabetes 54: 1808-1815.

37. Ishihara, H., Maechler, P., Gjinovci, A., Herrera, P. L. \& Wollheim, C. B. (2003) Islet beta-cell secretion determines glucagon release from neighbouring alpha-cells. Nat Cell Biol 5: 330-335.

38. Leung, Y. M., Ahmed, I., Sheu, L., Gao, X., Hara, M., Tsushima, R. G., Diamant, N. E. \& Gaisano, H. Y. (2006) Insulin regulates islet alpha-cell function by reducing KATP channel sensitivity to adenosine 5'-triphosphate inhibition. Endocrinology 147: 2155-2162.

39. Meier, J. J., Kjems, L. L., Veldhuis, J. D., Lefebvre, P. \& Butler, P. C. (2006) Postprandial suppression of glucagon secretion depends on intact pulsatile insulin secretion: further evidence for the intraislet insulin hypothesis. Diabetes 55: 1051-1056.

40. Shah, P., Basu, A., Basu, R. \& Rizza, R. (1999) Impact of lack of suppression of glucagon on glucose tolerance in humans. Am J Physiol 277: E283-290.

41. Basu, A., Alzaid, A., Dinneen, S., Caumo, A., Cobelli, C. \& Rizza, R. A. (1996) Effects of a change in the pattern of insulin delivery on carbohydrate tolerance in diabetic and nondiabetic humans in the presence of differing degrees of insulin resistance. J Clin Invest 97: 2351-2361.

42. Kabadi, U. M. (1991) Dose-kinetics of pancreatic alpha- and beta-cell responses to a protein meal in normal subjects. Metabolism 40: 236-240.

43. Lang, V., Bellisle, F., Alamowitch, C., Craplet, C., Bornet, F. R., Slama, G. \& Guy-Grand, B. (1999) Varying the protein source in mixed meal modifies glucose, insulin and glucagon kinetics in healthy men, has weak effects on subjective satiety and fails to affect food intake. Eur J Clin Nutr 53: 959-965.

44. Pipeleers, D. G., Schuit, F. C., Van Schravendijk, C. F. \& Van de Winkel, M. (1985) Interplay of nutrients and hormones in the regulation of glucagon release. Endocrinology 117: 817-823.

45. Miles, J. M. \& Jensen, M. D. (1993) Does glucagon regulate adipose tissue lipolysis? J Clin Endocrinol Metab 77: 5A-5B.

46. Albalat, A., Gomez-Requeni, P., Rojas, P., Medale, F., Kaushik, S., Vianen, G. J., Van den Thillart, G., Gutierrez, J., Perez-Sanchez, J. \& Navarro, I. (2005) Nutritional and hormonal control of lipolysis in isolated gilthead seabream (Sparus aurata) adipocytes. Am J Physiol Regul Integr Comp Physiol 289: R259-265.

47. Albalat, A., Gutierrez, J. \& Navarro, I. (2005) Regulation of lipolysis in isolated adipocytes of rainbow trout (Oncorhynchus mykiss): The role of insulin and glucagon. Comp Biochem Physiol A Mol Integr Physiol.

48. Gravholt, C. H., Moller, N., Jensen, M. D., Christiansen, J. S. \& Schmitz, O. (2001) Physiological levels of glucagon do not influence lipolysis in abdominal adipose tissue as assessed by microdialysis. J Clin Endocrinol Metab 86: 2085-2089.

49. Bertin, E., Arner, P., Bolinder, J. \& Hagstrom-Toft, E. (2001) Action of glucagon and glucagon-like peptide-1-(7-36) amide on lipolysis in human subcutaneous adipose tissue and skeletal muscle in vivo. J Clin Endocrinol Metab 86: 1229-1234.

50. Carlson, M. G., Snead, W. L. \& Campbell, P. J. (1993) Regulation of free fatty acid metabolism by glucagon. J Clin Endocrinol Metab 77: 11-15.

51. Perea, A., Clemente, F., Martinell, J., Villanueva-Penacarrillo, M. L. \& Valverde, I. (1995) Physiological effect of glucagon in human isolated adipocytes. Horm Metab Res 27: 372-375.

52. Merida, E., Delgado, E., Molina, L. M., Villanueva-Penacarrillo, M. L. \& Valverde, I. (1993) Presence of glucagon and glucagon-like peptide-1-(7-36)amide receptors in solubilized membranes of human adipose tissue. J Clin Endocrinol Metab 77: 1654-1657.

53. Richter, W. O., Robl, H. \& Schwandt, P. (1989) Human glucagon and vasoactive intestinal polypeptide (VIP) stimulate free fatty acid release from human adipose tissue in vitro. Peptides 10: 333-335. 
54. Paolisso, G., Buonocore, S., Gentile, S., Sgambato, S., Varricchio, M., Scheen, A., D'Onofrio, F. \& Lefebvre, P. J. (1990) Pulsatile glucagon has greater hyperglycaemic, lipolytic and ketogenic effects than continuous hormone delivery in man: effect of age. Diabetologia 33: 272-277.

55. Jensen, M. D., Caruso, M., Heiling, V. \& Miles, J. M. (1989) Insulin regulation of lipolysis in nondiabetic and IDDM subjects. Diabetes 38: 1595-1601.

56. Rolfe, D. F. \& Brown, G. C. (1997) Cellular energy utilization and molecular origin of standard metabolic rate in mammals. Physiol Rev 77: 731-758.

57. Flakoll, P. J., Borel, M. J., Wentzel, L. S., Williams, P. E., Lacy, D. B. \& Abumrad, N. N. (1994) The role of glucagon in the control of protein and amino acid metabolism in vivo. Metabolism 43: 15091516.

58. Charlton, M. R. \& Nair, K. S. (1998) Role of hyperglucagonemia in catabolism associated with type 1 diabetes: effects on leucine metabolism and the resting metabolic rate. Diabetes 47: 1748-1756.

59. Nair, K. S. (1987) Hyperglucagonemia increases resting metabolic rate in man during insulin deficiency. J Clin Endocrinol Metab 64: 896-901.

60. Nair, K. S., Halliday, D., Matthews, D. E. \& Welle, S. L. (1987) Hyperglucagonemia during insulin deficiency accelerates protein catabolism. Am J Physiol 253: E208-213.

61. Charlton, M. R., Adey, D. B. \& Nair, K. S. (1996) Evidence for a catabolic role of glucagon during an amino acid load. J Clin Invest 98: 90-99.

62. Robinson, S. M., Jaccard, C., Persaud, C., Jackson, A. A., Jequier, E. \& Schutz, Y. (1990) Protein turnover and thermogenesis in response to high-protein and high-carbohydrate feeding in men. Am J Clin Nutr 52: 72-80.

63. Swaminathan, R., King, R. F., Holmfield, J., Siwek, R. A., Baker, M. \& Wales, J. K. (1985) Thermic effect of feeding carbohydrate, fat, protein and mixed meal in lean and obese subjects. Am J Clin Nutr 42: 177-181.

64. Karst, H., Steiniger, J., Noack, R. \& Steglich, H. D. (1984) Diet-induced thermogenesis in man: thermic effects of single proteins, carbohydrates and fats depending on their energy amount. Ann Nutr Metab 28 : 245-252.

65. Nair, K. S., Halliday, D. \& Garrow, J. S. (1983) Thermic response to isoenergetic protein, carbohydrate or fat meals in lean and obese subjects. Clin Sci (Lond) 65: 307-312.

66. Westerterp-Plantenga, M. S., Rolland, V., Wilson, S. A. \& Westerterp, K. R. (1999) Satiety related to 24 $\mathrm{h}$ diet-induced thermogenesis during high protein/carbohydrate vs high fat diets measured in a respiration chamber. Eur J Clin Nutr 53: 495-502.

67. Torres, N., Torre-Villalvazo, I. \& Tovar, A. R. (2006) Regulation of lipid metabolism by soy protein and its implication in diseases mediated by lipid disorders. J Nutr Biochem 17: 365-373.

68. McCarty, M. F. (1999) Vegan proteins may reduce risk of cancer, obesity, and cardiovascular disease by promoting increased glucagon activity. Med Hypotheses 53: 459-485.

69. Sugano, M., Ishiwaki, N. \& Nakashima, K. (1984) Dietary protein-dependent modification of serum cholesterol level in rats. Significance of the arginine/lysine ratio. Ann Nutr Metab 28: 192-199.

70. Sanchez, A. \& Hubbard, R. W. (1991) Plasma amino acids and the insulin/glucagon ratio as an explanation for the dietary protein modulation of atherosclerosis. Med Hypotheses 36: 27-32.

71. Hubbard, R., Kosch, C. L., Sanchez, A., Sabate, J., Berk, L. \& Shavlik, G. (1989) Effect of dietary protein on serum insulin and glucagon levels in hyper- and normocholesterolemic men. Atherosclerosis 76: 55-61.

72. Palmer, J. P., Walter, R. M. \& Ensinck, J. W. (1975) Arginine-stimulated acute phase of insulin and glucagon secretion. I. in normal man. Diabetes 24: 735-740.

73. Spiller, G. A., Jensen, C. D., Pattison, T. S., Chuck, C. S., Whittam, J. H. \& Scala, J. (1987) Effect of protein dose on serum glucose and insulin response to sugars. Am J Clin Nutr 46: 474-480. 


\section{Chapter 2}

\section{The effect of different protein \\ hydrolysate/carbohydrate mixtures on postprandial glucagon and insulin responses in healthy subjects}

Mandy Claessens ${ }^{1}$, Wim Calame ${ }^{2}$, André D Siemensma ${ }^{2}$, Marleen A van Baak ${ }^{1}$, Wim HM Saris ${ }^{1}$

Nutrition and Toxicology Research Institute Maastricht (NUTRIM), Department of Human Biology, Maastricht University, Maastricht, The Netherlands ${ }^{1}$; Kerry BioScience, Almere, The Netherlands ${ }^{2}$

This work was supported by Kerry Bio-Science, Almere, The Netherlands

Based on: Eur J Clin Nutr, 2007 (in press) 


\begin{abstract}
Objective: To study the effect of 4 protein hydrolysates from vegetable (pea, gluten, rice and soy) and 2 protein hydrolysates from animal origin (whey and egg) on glucagon and insulin responses.

Design: The study employed a repeated measures design with Latin square randomization and single-blind trials. Protein hydrolysates used in this study (pea, rice, soy, gluten, whey and egg protein hydrolysate) consisted of $0.2 \mathrm{~g}$ hydrolysate $/ \mathrm{kg}$ body weight $(\mathrm{BW})$ and $0.2 \mathrm{~g}$ maltodextrin $/ \mathrm{kg} \mathrm{BW}$ and were compared to maltodextrin alone. Postprandial plasma glucose, glucagon, insulin and amino acids were determined over 2 hours.

Subjects: Eight healthy normal-weight male subjects.

Results: All protein hydrolysates induced an enhanced insulin secretion compared to maltodextrin alone and a correspondingly low plasma glucose response. A significant difference was observed in area under the curve for plasma glucagon between protein hydrolysates and the maltodextrin control drink $(\mathrm{p}<0.05)$. Gluten protein hydrolysate induced the lowest glucagon response.

Conclusion: High amino acid-induced glucagon response does not necessarily go together with low insulin response. Protein hydrolysate source affects AUC for glucagon more profoundly than for insulin, although the protein load used in this study seemed to be at lower level for significant physiological effects.
\end{abstract}




\section{Introduction}

Previous research has demonstrated that co-ingestion of proteins with carbohydrates results in increased plasma insulin responses $(1,2)$ and this both in healthy subjects $(3$, 4) and in patients with type 2 diabetes (5-7). The effect of proteins on insulin secretion is mainly a consequence of the effect that specific amino acids (AA) in the blood have on pancreatic $\beta$-cell activity (8). Similarly, glucagon secretion is induced by the effect of amino acids in the blood on pancreatic $\alpha$-cells (4). The effect of proteins on the carbohydrate-induced insulin response has been studied most frequently, since this is of interest in type 2 diabetic patients $(3,6,7)$. Although glucagon is not an as extensively studied hormone as insulin, glucagon secretion is disturbed in both type 1 and type 2 diabetic patients. In both cases a lack of glucagon suppression due to delayed and depressed insulin secretion, is thought to contribute to postprandial hyperglycemia (9). The observation that proteins induce both insulin and glucagon secretion $(4,10)$ is interesting. Because insulin antagonizes glucagon secretion, proteins or amino acids inducing high insulin responses could be expected to induce rather low glucagon responses while proteins that induce low insulin responses might induce relatively high glucagon levels. The reason we are interested in the glucagon response to protein intake is that, although literature is not conclusive, some studies show that glucagon induces lipolysis $(11,12)$. In this regard, increased glucagon concentrations might be beneficial in the management of obesity.

The purpose of the present study was to investigate whether a carbohydrate load with co-ingestion of protein hydrolysates of different vegetable (soy, rice, gluten and pea) and animal (egg and whey) origin induce different glucagon responses and whether these differences can be explained by differences in insulin responses and/or changes in plasma amino acid concentrations. To prevent differences in stomach emptying protein hydrolysates were used (13). Because previous research reported that both plasma insulin and glucagon secretion can be significantly stimulated by low protein concentrations $(0.25 \mathrm{~g} / \mathrm{kg} \mathrm{BW})$, in the present study $0.2 \mathrm{~g} / \mathrm{kg} \mathrm{BW}$ protein hydrolysate was used combined with an isocaloric amount of carbohydrates. Since protein hydrolysates are not very tasty and since high concentrations might cause gastrointestinal discomfort (3) we decided to keep concentrations as low as possible, so that results might be applicable to daily life situations. 


\section{Methods}

\section{Subjects}

Eight healthy non-obese male subjects participated in this study (age $32 \pm 13.8$ year, weight $76.2 \pm 4.7 \mathrm{~kg}$, height $1.79 \pm 0.04 \mathrm{~m}$, BMI $23.7 \pm 1.4 \mathrm{~kg} / \mathrm{m}^{2}$; means \pm SEM). All subjects were informed about the nature and risks of the experimental procedures and their informed consent was obtained. The local Medical Ethical Committee approved this study.

\section{Experimental design}

The study consisted of 7 trials in which 6 different protein hydrolysates and 1 control beverage (see beverages) were tested. All beverages were artificially sweetened and lemon flavoured in order to make differences in taste as small as possible. Beverages were offered randomly (by means of Latin square randomization) and in untransparent mugs in order to obtain single-blind trials. Testing days were separated by at least 2 days. At testing days, subjects came to the lab after an overnight fast and they were asked to avoid heavy physical activity the day before the trials and to keep their eating pattern as constant as possible.

\section{Beverages}

All beverages (approximately $250 \mathrm{ml}$ ) offered to the subjects contained $0.2 \mathrm{~g}$ protein hydrolysate/kg body weight (BW) (Kerry Bio-Science, Almere, The Netherlands) and $0.2 \mathrm{~g}$ maltodextrin/kg BW (AVB, Veendam, The Netherlands) except for the control drink that only contained $0.2 \mathrm{~g}$ maltodextrin $/ \mathrm{kg} \mathrm{BW} 0.2 \mathrm{~g}$ protein hydrolysate $/ \mathrm{kg} \mathrm{BW}$ is approximately $25 \%$ of the Recommended Daily Allowance (RDA) for proteins according to US Guidelines $(0.8 \mathrm{~g} / \mathrm{kg} \mathrm{BW})$ and $45 \%$ of recommended protein intake according to WHO $(0.45 \mathrm{~g} / \mathrm{kg} \mathrm{BW})(14)$. Compared to the average protein intake of the Dutch population, $0.2 \mathrm{~g} / \mathrm{kg} \mathrm{BW}$ accounts for a protein load somewhere between breakfast (0.13 g/kg BW) and lunch (0.35 g/kg BW) (15). All beverages were uniformly lemon flavoured (Quest International, Naarden, The Netherlands) and sweetened with aspartame. To achieve an optimal $\mathrm{pH}$ for the flavouring compound, $0.26 \%$ citric acid was incorporated. Protein hydrolysates were made via an enzymatic procedure and the degree of hydrolysis of the protein drinks ranged between 9 and 27\%. The amino acid composition of the hydrolysates was determined by HPLC analysis (Lithium system, Jeol Inc., Tokyo, Japan) of free amino acids after precipitation of large peptides/proteins and compared to results of standard samples. Amino acid profiles of the different test drinks are given in Table 2.1 . 
Table 2.1 Amino acid composition of the protein hydrolysates

\begin{tabular}{lllllll}
\hline Amino acids & Pea & Rice & Soy & Gluten & Whey & Egg \\
\hline Aspartic acid (Asx)* & 11.7 & 10.1 & 12.1 & 2.5 & 11.0 & 10.2 \\
Serine (Ser) & 5.7 & 5.7 & 5.2 & 5.2 & 5.7 & 7.0 \\
Glutamic Acid (Glx)* & 19.9 & 20.0 & 19.7 & 38.4 & 18.6 & 13.3 \\
Histidine (His) & 2.4 & 2.2 & 2.5 & 1.9 & 1.8 & 2.3 \\
Glycine (Gly) & 4.0 & 4.5 & 4.3 & 3.3 & 1.8 & 3.5 \\
Threonine (Thr) & 4.0 & 4.0 & 3.9 & 2.4 & 7.4 & 4.6 \\
Arginine (Arg) & 9.8 & 8.1 & 7.4 & 2.6 & 2.3 & 5.4 \\
Alanine (Ala) & 5.4 & 6.0 & 4.4 & 2.2 & 5.3 & 5.8 \\
Tyrosine (Tyr) & 3.7 & 4.7 & 3.1 & 3.0 & 2.6 & 3.9 \\
Valine (Val) & 3.9 & 5.5 & 3.9 & 3.6 & 5.1 & 6.4 \\
Methione (Met) & 0.9 & 2.1 & 1.2 & 1.3 & 1.5 & 3.4 \\
Isoleucine (Ile) & 3.4 & 3.7 & 3.7 & 3.1 & 5.7 & 5.7 \\
Phenylalanine (Phe) & 4.6 & 4.9 & 4.9 & 5.7 & 2.7 & 5.8 \\
Tryptophan (Trp) & 0.4 & 1.3 & 1.3 & 1.2 & 1.4 & 1.2 \\
Leucine (Leu) & 7.3 & 8.0 & 7.5 & 6.7 & 9.8 & 8.5 \\
Lysine (lys) & 8.4 & 3.9 & 6.6 & 1.2 & 9.5 & 6.9 \\
Proline (Pro) & 4.0 & 4.5 & 6.4 & 14.7 & 6.6 & 3.9 \\
Cysteine (Cys) & 0.6 & 0.9 & 2.2 & 1.1 & 1.4 & 2.2 \\
\hline Values expressed as percentage & 0.9 & & & & \\
\hline
\end{tabular}

Values expressed as percentage of total dry product

*Asx: Asparagine + Aspartic acid; Glx: glutamate + glutamine

\section{Protocol}

After an overnight fast, subjects reported to the laboratory where a Teflon catheter (Baxter BV, Utrecht, The Netherlands) was inserted into an antecubital vein and a resting blood sample was drawn $(\mathrm{t}=0)$. Then subjects were offered the test drink, which they had to consume as fast as possible and at least within 5 minutes. Blood samples were drawn 15, 30, 60, 90 and 120 minutes after finishing the test drink for glucose, amino acid, insulin and glucagon analyses.

\section{Blood analysis}

Blood was collected in EDTA containing tubes for glucose, insulin and free amino acid analysis. EDTA blood to which aprotinin ( 5 kIU/ml blood; Sigma-Aldrich Chemie BV) was added was used for glucagon analysis. After collection the blood sample was centrifuged at $1000 \mathrm{~g}$ at $4^{\circ} \mathrm{C}$ for $10 \mathrm{~min}$. Aliquots of plasma were frozen immediately in liquid nitrogen and stored at $-45^{\circ} \mathrm{C}$. Glucose was analyzed with the COBAS FARA semi automatic analyzer (Uni Kit III, 07367204, Roche, Basel, Switzerland). Insulin was analyzed by radioimmunoassay (Human Insulin Specific RIA Kit, LINCO Research Inc., Missouri, USA) as was glucagon (Glucagon RIA Kit, LINCO Research 
Inc., Missouri, USA). Plasma free amino acids were analyzed by HPLC technique after precolumn derivatization with o-phthaldialdehyde as described previously (16).

\section{Statistics}

All data are expressed as means \pm SEM $(n=8)$. Plasma glucose, insulin, glucagon and amino acid responses were calculated as total area under the curve (AUC) (AUC above - AUC below baseline $($ at $t=0)$ ). Since on average the highest plasma concentrations for most variables were found $30 \mathrm{~min}$ after ingestion of the drinks $(t=30)$ the concentration changes from baseline to $t=30$ (delta 30 ) were calculated by subtracting basal concentrations from concentrations at $\mathrm{t}=30 \mathrm{~min}$. Statistical analysis was performed by using SPSS for Mac OS X software (SPSS Inc, Chicago, IL). Differences in AUC over $120 \mathrm{~min}$ were assessed by repeated-measures ANOVA with AUC for different treatments as within-subject factor. Baseline and delta 30 values were also tested by means of repeated- measures ANOVA with delta 30 values for different treatments as within-subjects factor. Post-hoc tests with Bonferroni correction were used to identify the drinks between which the differences existed. We tested whether responses induced by protein hydrolysates differed from the control drink (Bonferroni correction for 6 comparisons) and whether responses of different protein hydrolysates differed from each other (Bonferroni correction for 15 comparisons). Multiple linear regression analysis was used to determine which group of amino acids (total AA, essential AA, branched-chain AA or total AA) is the best predictor for insulin and glucagon responses. Therefore, amino acids were grouped into essential amino acids (EAA: Val, Ile, Leu, His, Lys, Met, Phe, Thr, Trp), branched-chain amino acids (BCAA: Val, Ile, Leu) and total amino acids. Because these groups of AA correlate strongly with each other, it is not allowed to analyse them in one model. Therefore, the different groups were included in the model in separate analyses. The observed insulin or glucagon concentration at each time point (6), for each amino acid containing solution (6) and for each subject (8) (288 measurements) was analysed as a linear regression model with subject, solution, time point, glucose concentration and amino acid group (EAA, BCAA or total AA) as independent variables. The effect of each group of amino acids (EAA, BCAA or TAA) was tested with the above-defined model and was therefore corrected for all other included variables. At a p-level of 0.05 or smaller results were considered significantly different. 


\section{Results}

As table 2.2 shows, baseline values for glucose, insulin and glucagon were similar for all test drinks.

All test drinks induced a glucose response that reached peak levels at 15-30 minutes after consumption, decreased in all cases to below baseline after $60 \mathrm{~min}$ and almost reached baseline values again after 120 minutes (Figure 2.1A).

Table 2.2 Baseline values for all test solutions

\begin{tabular}{lccc}
\hline & Glucose $(\mathrm{mmol} / \mathrm{L})$ & Insulin $(\mathrm{pmol} / \mathrm{L})$ & Glucagon $(\mathrm{ng} / \mathrm{L})$ \\
\hline Pea & $5.46 \pm 0.11$ & $86.47 \pm 9.80$ & $71.69 \pm 7.26$ \\
Rice & $5.39 \pm 0.14$ & $80.73 \pm 7.98$ & $71.08 \pm 6.00$ \\
Soy & $5.58 \pm 0.14$ & $89.68 \pm 9.12$ & $65.63 \pm 6.13$ \\
Gluten & $5.38 \pm 0.09$ & $83.75 \pm 4.73$ & $73.16 \pm 6.10$ \\
Whey & $5.38 \pm 0.13$ & $80.55 \pm 9.36$ & $71.74 \pm 4.46$ \\
Egg & $5.39 \pm 0.09$ & $83.31 \pm 8.57$ & $75.90 \pm 6.94$ \\
CHO & $5.08 \pm 0.16$ & $67.25 \pm 4.76$ & $73.07 \pm 5.13$ \\
p-value & 0.202 & 0.388 & 0.950 \\
\hline
\end{tabular}

Values are means \pm SEM

Delta 30 values were significantly lower after pea, soy, gluten and whey protein hydrolysate consumption as compared to the control drink $(p<0.025)$, no differences in delta 30 values were found between the different protein hydrolysates. The glucose AUCs for pea, soy, gluten and whey protein hydrolysates differed significantly from the AUC for the control drink $(\mathrm{p}<0.006)$ but AUCs did not differ between the 6 protein hydrolysates (Figure 2.1B).

In all cases an insulin peak was reached $30 \mathrm{~min}$ after consumption of the test drink (Figure 2.2A). Delta 30 values for insulin differed significantly between the control drink and pea, rice and whey protein hydrolysate drinks $(\mathrm{p}<0.04)$. All protein hydrolysate/carbohydrate mixtures except soy protein hydrolysate, induced significantly higher AUC of insulin than the control drink $(\mathrm{p}<0.05)$. No significant differences among the 6 protein hydrolysates in AUCs of insulin were found (Figure 2.2B). 

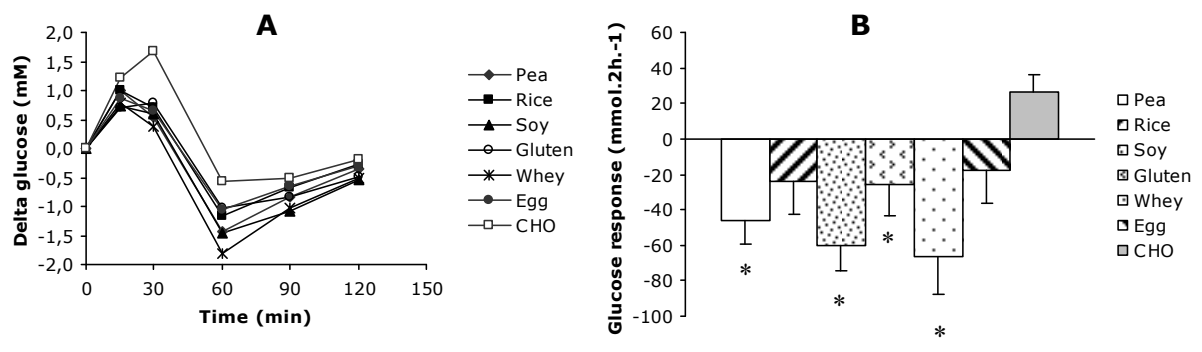

\section{Figure 2.1}

$\Delta$ - Plasma glucose concentrations (change from baseline values) (mmol. $\mathrm{L}^{-1}$ ) (A) and responses expressed as total area under the curve $\left(\mathrm{mmol}^{\bullet} 2 \mathrm{~h}^{\bullet} \mathrm{L}^{-1}\right)(\mathrm{B})$ after consumption of control and experimental drinks. Values are means \pm SEM; *, significantly different from the glucose response induced by the control $\operatorname{drink}(\mathrm{p}<0.05)$.
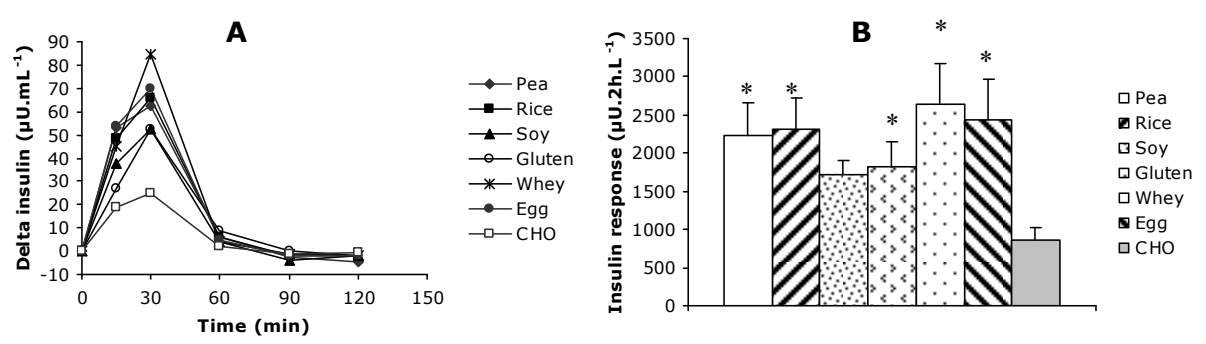

Figure 2.2

$\Delta$ - Plasma insulin concentrations (change from baseline values) $\left(\mu \mathrm{U} \bullet \mathrm{mL}^{-1}\right)(\mathrm{A})$ and responses expressed as total area under the curve $\left(\mu \mathrm{U}^{\bullet} 2 \mathrm{~h}^{\bullet} \mathrm{mL}^{-1}\right)$ (B) after consumption of control and experimental drinks. Values are means $\pm \mathrm{SEM} ;{ }^{*}$, significantly different from the insulin response induced by the control drink $(\mathrm{p}<0.05)$.

In Figure 2.3A glucagon response over time induced by the different experimental drinks are depicted. Delta 30 values were significantly higher for all experimental drinks compared to the control drink $(p<0.005)$. When comparing delta 30 values of the different protein hydrolysates only soy protein hydrolysate induced significantly higher delta 30 values for glucagon than gluten protein hydrolysate. $(p=0.02)$. All protein hydrolysates induced significantly higher AUCs for glucagon compared to the carbohydrate drink $(\mathrm{p}<0.01)$ (Figure 3B). Among hydrolysates, AUCs for glucagon between gluten and egg protein hydrolysates differed significantly $(p=0.02)$. 

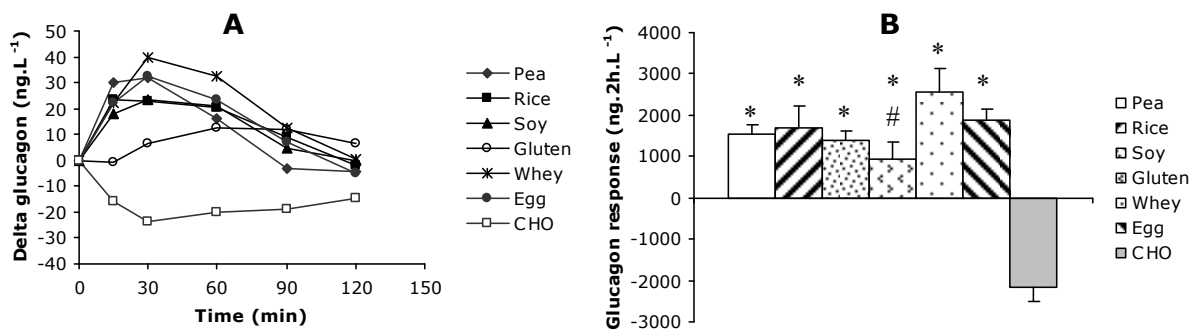

Figure 2.3

$\Delta$ - Plasma glucagon concentrations (change from baseline values) (ng $\left.\bullet \mathrm{L}^{-1}\right)(\mathrm{A})$ and responses expressed as total area under the curve $\left(\mathrm{ng} \bullet 2 \mathrm{~h} \bullet \mathrm{L}^{-1}\right)(\mathrm{B})$ after consumption of control and experimental drinks. Values are means \pm SEM; 3B: *, significantly different from the glucagon response after ingestion of the carbohydrate drink ( $\mathrm{p}<0.01$ ); \#, significantly different from the glucagon response induced by egg protein hydrolysate.

AUCs for mean plasma amino acids for the different protein drinks are reported in Table 2.3. As depicted in table 2.3 an overall effect of drinks was found for asparagine $(p=0.002)$, threonine $(p=0.000)$, arginine $(p=0.000)$, tyrosine $(p=0.031)$, methionine $(\mathrm{p}=0.026)$, isoleucine $(\mathrm{p}=0.030)$ and lysine $(\mathrm{p}=0.000)$. Between which protein drinks these differences are situated is indicated in Table 2.3.

Multiple linear regression analyses showed that the model corrected for subject, drink, time and glucose but without any group of amino acids, explained $39 \%$ of the variability in insulin response. When BCAA (Val, Ile, Leu) were included in this model it explained $73 \%$ of the variability in insulin response (partial correlation of 0.75 ; $p<$ 0.001). Inclusion of EAA (Val, Ile, Leu, His, Lys, Met, Phe, Thr and Trp) or TAA explained in both cases $68 \%$ of the variability.

In case of the glucagon response, the model corrected for subject, drink, time and glucose but without any group of AA, explained $24 \%$ of the variability. After addition of BCAA to the model it explained $50 \%$ of the variability in glucagon response (partial correlation of $0.60 ; p<0.001)$. When EAA or TAA were included in the model $43 \%$ (partial correlation of $0.50, \mathrm{p}<0.001$ ) or $40 \%$ (partial correlation of $0.47, \mathrm{p}<0.001$ ) of the variation, respectively. Arginine, the amino acid mostly used to induce in vitro glucagon secretion (17) did not improve the model to which BCAA were added significantly $(\mathrm{p}=0.539)$. 
Chapter 2

\section{Discussion}

This study was performed to investigate whether co-ingestion of carbohydrates and protein hydrolysates of different vegetable and animal origin induce different glucagon responses upon consumption and whether these differences are related to differences in insulin responses and/or changes in plasma amino acid concentrations. Our main findings are that the insulin response to the different protein hydrolysate/carbohydrate mixtures was comparable but significantly higher than the control carbohydrate drink, that all protein hydrolysates induced higher AUCs for glucagon than maltodextrin alone and that gluten protein hydrolysate induced significantly lower AUC for glucagon compared to egg protein hydrolysate. Branched-chain AA (Val, Ile and Leu) were best predictors for both the insulin and glucagon response.

Table 2.1 and 2.3 and figures 2.4 and 2.5 show that in general protein drinks with high concentrations of certain amino acids also induce high plasma responses and AUCs of these AA. Whey protein hydrolysate, for instance, with relatively high amounts of Ile, Leu, Lys, Thr and Val (Table 2.1) induced higher AUCs for these AA (Table 2.3). 


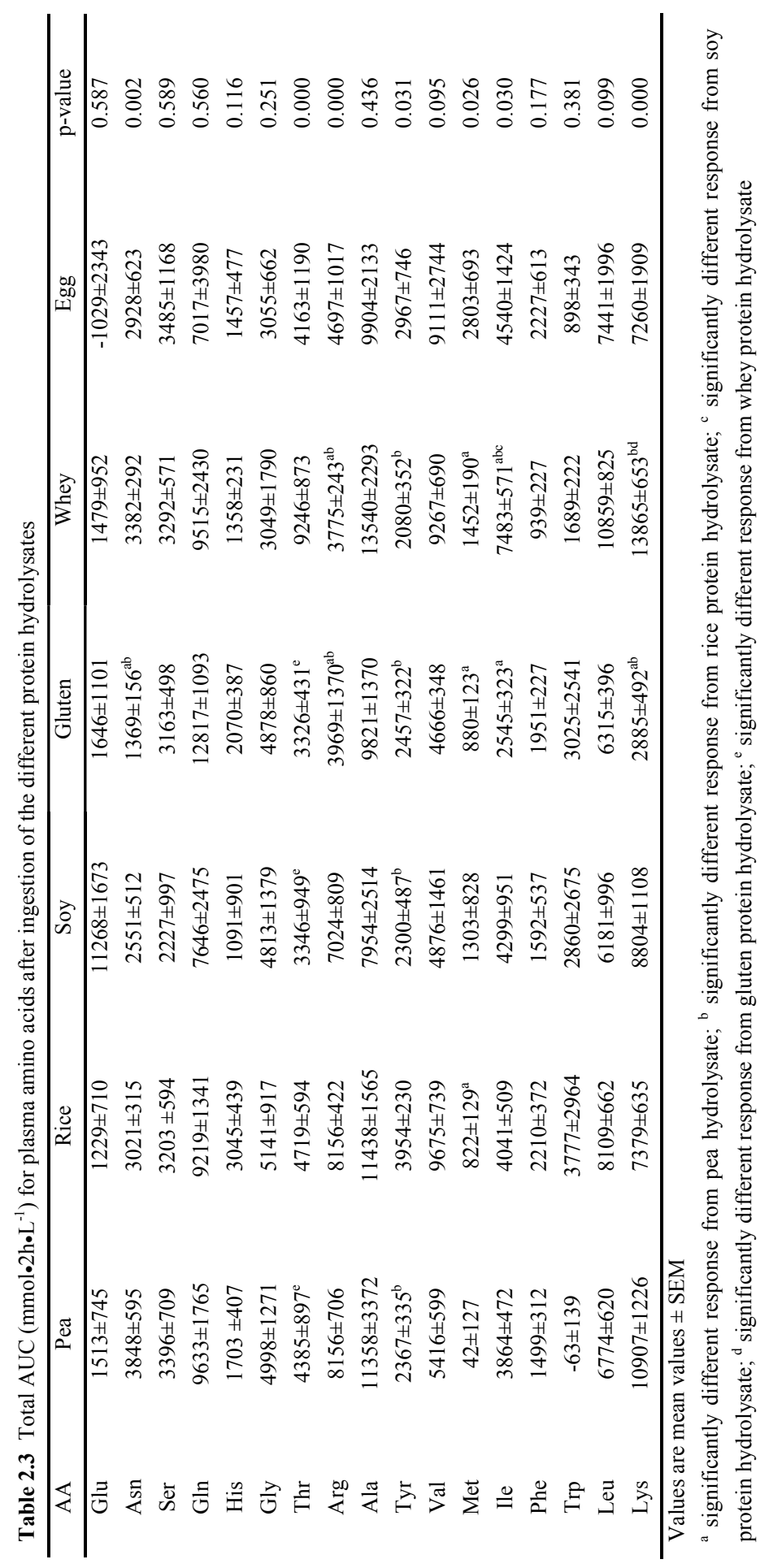


Interestingly, egg protein hydrolysate that consists of relatively high amounts of Ile, Ser and Val does not seem to induce high AUC for Ser and Ile. When looking at Figure 2.4 and 2.5 this is most probably due to the small differences in AA responses between drinks.
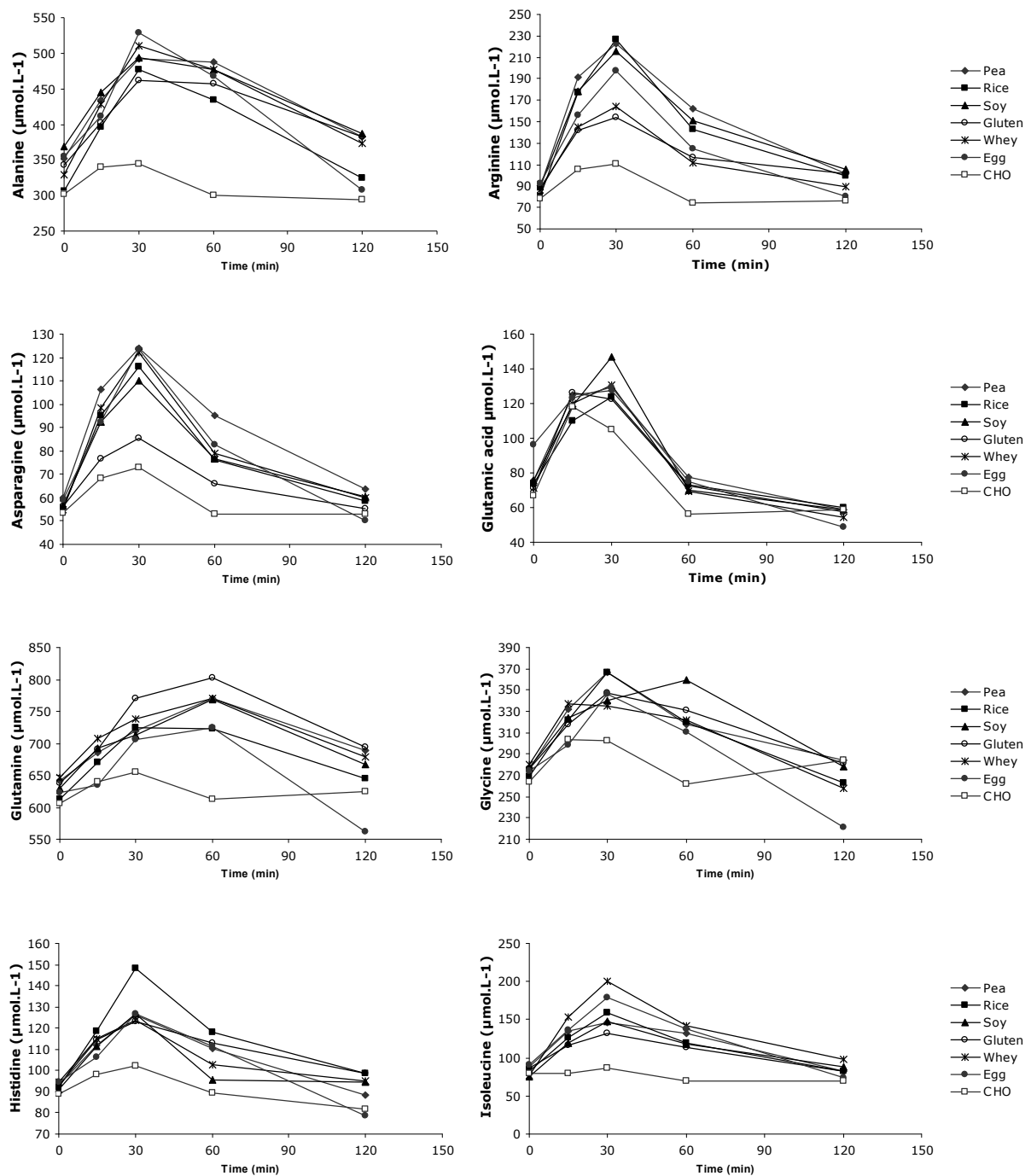

\section{Figure 2.4}

Plasma concentrations for Ala, Arg, Asp, Glu, Gln, Gly. His and Ile during the postprandial period after consumption of the control and experimental drinks. 

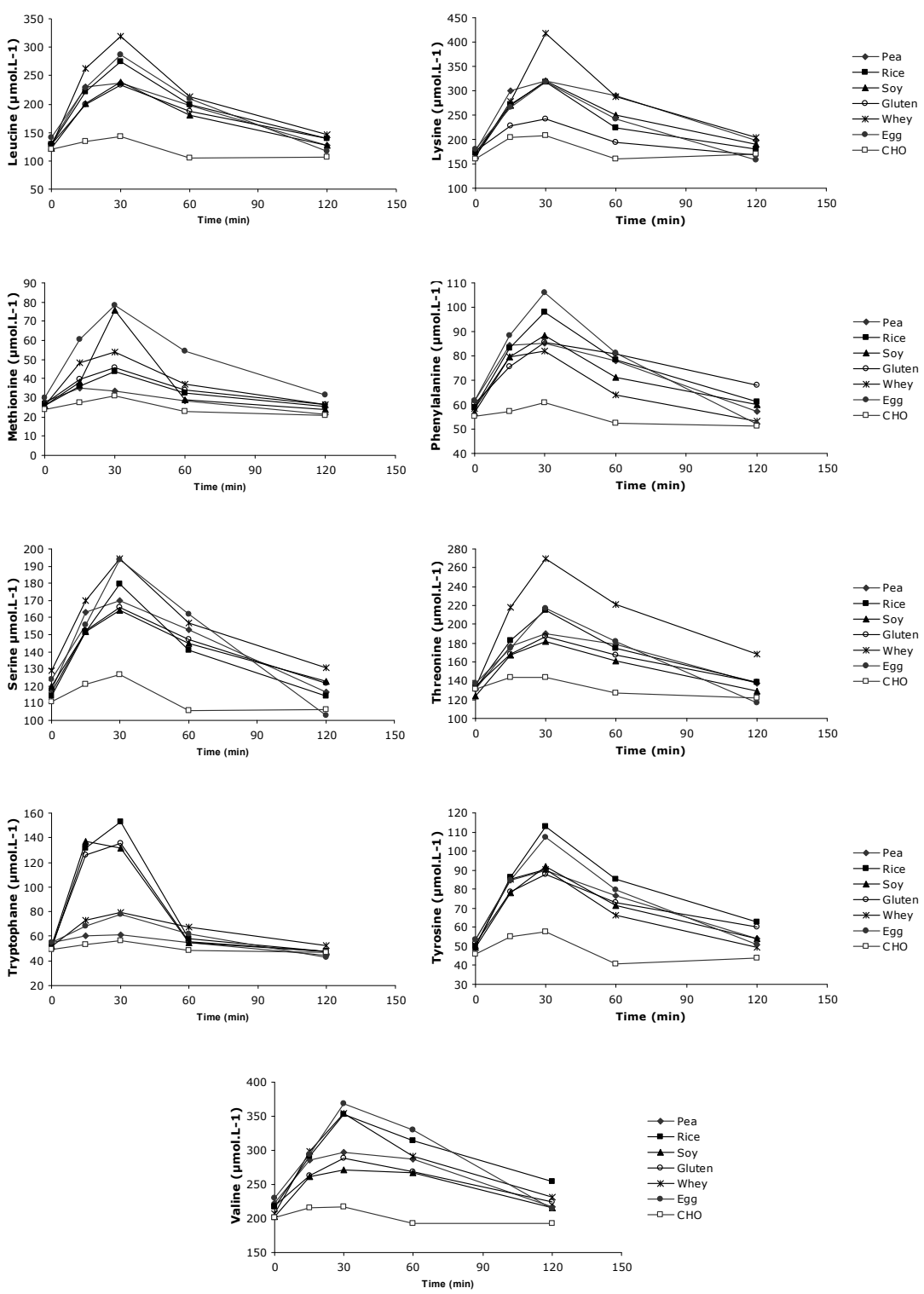

\section{Figure 2.5}

Plasma concentrations for Leu, Lys, Met, Phe, Ser, Thr, Trp, Tyr and Val during the postprandial period after consumption of the control and experimental drinks. 
Interestingly, plasma amino acid responses after the control carbohydrate drink also showed small increases over time (Figure 2.4). Although the mechanism is not clear, it can be speculated that carbohydrate consumption influences the labile protein pool in the splanchnic area to secrete small amounts of AA or that it changes the balance between endogenous amino acid production and utilization.

The results of this study show that all protein hydrolysate mixtures enhanced the carbohydrate-induced insulin response resulting in lower plasma glucose concentrations. No differences in glucose and insulin response among protein hydrolysate mixtures were found. A stimulation of the insulin response after ingestion of protein hydrolysates has been reported before. Van Loon et al (2000) (3) gave cumulative boluses of a large number of different protein hydrolysates or free amino acids mixed with carbohydrates to 8 healthy non-obese male subjects with final protein concentrations twice as high and carbohydrate concentrations 4 times higher (3) than the concentrations used in the present study. Most mixtures showed higher insulin responses than the control carbohydrate drink, but from the protein hydrolysates that were also used in our study only wheat protein hydrolysate resulted in a significantly higher insulin response (3). Also in our study gluten (a protein found in wheat) protein hydrolysate did result in a higher AUC for insulin when compared to a carbohydrate load alone. A study performed by Calbet and MacLean (2002) (4), in which subjects received pea or whey protein hydrolysate/glucose mixture, a complete milk/glucose solution or a control glucose solution via a gastroduodenal catheter, at dosages only slightly higher than in our study, did report significantly higher insulin responses for both protein hydrolysates (4 times higher) and the milk solution ( 2 times higher) compared to the control drink, with no significant difference between whey and pea protein hydrolysates which is in accordance with our results.

Thus, at a protein intake slightly higher than a standard Dutch breakfast, oral ingestion of protein hydrolysates mixed with the same amount of carbohydrates induces higher AUCs for insulin compared to a carbohydrate load alone. At this concentration protein source does not influence the insulin response substantially.

All protein hydrolysate mixtures resulted in a significantly higher AUC for glucagon than the control drink. This is in accordance with the findings of van Hall and colleagues who found that during the recovering period from intense cycle exercise repeated carbohydrate ingestion alone induced a strong reduction in plasma glucagon levels while when plasma amino acid levels were kept elevated during 4 hours by repeated consumption of a whey protein hydrolysate/sucrose mixture, glucagon levels decreased less (18). In addition to the direct glucagon-stimulating effect of amino acids $(10,19)$ the fall in glucose concentrations due to the higher insulin response induced by the carbohydrate/protein hydrolysate drinks might have contributed to the prolonged 
glucagon response. Hydrolysates of slowly digestible proteins such as casein may induce faster amino acid and hormonal responses than the intact protein $(20,21)$. However, for hydrolysates of other proteins that are digested faster, such as whey protein, the difference is smaller $(22,23)$. Among the protein hydrolysate mixtures only the AUC for glucagon to gluten and egg protein hydrolysate mixtures differed statistically significant $(p=0.02)$. Interestingly, gluten protein hydrolysate induced rather low peak concentrations, but the response was maintained longer than all other glucagon responses. We do not expect protein digestibility or gastric emptying to be responsible for these differences since protein hydrolysates of similar volume, osmolality and energy density and under similar conditions ( $\mathrm{pH}$ and temperature) were used to overcome these problems (13). Whether this different glucagon response to the gluten protein hydrolysate mixture has a physiological meaning has to be investigated further. Glucagon responses to pea and whey protein hydrolysate injection did not differ significantly in the study conducted by Calbet and MacLean (2002) (4), which is in agreement with our findings. Calbet and Holst (2004) reported that whey and casein protein hydrolysate consumption induced similar insulin and glucagon responses suggesting that small differences in the amino acid composition do not influence hormone secretion (20). In the present study we found that amino acid composition can influence hormone secretion and that this effect is more pronounced for glucagon than for insulin. Although protein hydrolysates inducing high peak concentrations for insulin were expected to antagonize glucagon secretion afterwards, which would lead to rapid declines in glucagon concentrations from $30 \mathrm{~min}$ on, this was not found. While egg protein hydrolysate induced a similar AUC for insulin as gluten protein hydrolysate, egg protein hydrolysate induced significantly higher AUC for glucagon ( $p=0.02$ ). Therefore, in the present study differences in glucagon responses cannot be explained by different insulin responses.

Based on the amino acid composition of the mixtures and previous data $(3,4,24-27)$ we expected egg protein hydrolysate to induce the highest peak concentrations for insulin and glucagon, gluten protein hydrolysate to induce the lowest peak concentrations for insulin, and whey protein hydrolysate to induce the lowest peak concentrations for glucagon. Instead the only significant difference between the drinks was a lower glucagon response after the gluten hydrolysate as compared to egg protein hydrolysate. In the present study, the BCAA, were the best predictors for both the insulin and glucagon response. When linking this with the amino acid composition of the experimental drinks, whey protein hydrolysate contained the highest amount of BCAA and therefore should have induced the highest insulin and glucagon responses, which is in accordance with our results. Gluten protein hydrolysate, on the other hand, contained 
fewest BCAA and induced a rather low insulin response (only soy protein hydrolysate induced a lower insulin response) and the lowest glucagon response although these differences did not reach significance. This predictive effect of BCAA for insulin and glucagon secretion might also explain the discrepancy between the findings of our study and the study of Calbet \& Holst since the protein solutions in the latter study all contained similar amounts of BCAA (20).

In summary, $0.2 \mathrm{~g} / \mathrm{kg} \mathrm{BW}$ protein hydrolysate in combination with $0.2 \mathrm{~g} / \mathrm{kg} \mathrm{BW}$ maltodextrin increased plasma insulin compared to $0.2 \mathrm{~g} / \mathrm{kg} \mathrm{BW}$ maltodextrin alone, with correspondingly lower glucose concentrations, with no significant differences among the different hydrolysates. Protein hydrolysate mixtures significantly increased AUCs for glucagon compared to the carbohydrate control drink. Gluten protein hydrolysate showed the lowest but more prolonged glucagon response. Peak concentrations for insulin do not seem to be responsible for differences in glucagon responses. The amino acid-induced insulin and glucagon responses appear to be independent of each other and are both dependent on BCAA concentrations.

\section{Acknowledgements}

We would like to thank the laboratory of Mick Deutz for performing the plasma amino acid measurements. 


\section{References}

1. Pallotta, J. A. \& Kennedy, P. J. (1968) Response of plasma insulin and growth hormone to carbohydrate and protein feeding. Metabolism 17: 901-908.

2. Rabinowitz, D., Merimee, T. J., Maffezzoli, R. \& Burgess, J. A. (1966) Patterns of hormonal release after glucose, protein, and glucose plus protein. Lancet 2: 454-456.

3. van Loon, L. J., Saris, W. H., Verhagen, H. \& Wagenmakers, A. J. (2000) Plasma insulin responses after ingestion of different amino acid or protein mixtures with carbohydrate. Am J Clin Nutr 72: 96-105.

4. Calbet, J. A. \& MacLean, D. A. (2002) Plasma glucagon and insulin responses depend on the rate of appearance of amino acids after ingestion of different protein solutions in humans. J Nutr 132: 21742182.

5. Nuttall, F. Q., Mooradian, A. D., Gannon, M. C., Billington, C. \& Krezowski, P. (1984) Effect of protein ingestion on the glucose and insulin response to a standardized oral glucose load. Diabetes Care 7: 465-470.

6. Manders, R. J., Wagenmakers, A. J., Koopman, R., Zorenc, A. H., Menheere, P. P., Schaper, N. C., Saris, W. H. \& van Loon, L. J. (2005) Co-ingestion of a protein hydrolysate and amino acid mixture with carbohydrate improves plasma glucose disposal in patients with type 2 diabetes. Am J Clin Nutr 82: 76-83.

7. Manders, R. J., Koopman, R., Sluijsmans, W. E., van den Berg, R., Verbeek, K., Saris, W. H., Wagenmakers, A. J. \& van Loon, L. J. (2006) Co-ingestion of a protein hydrolysate with or without additional leucine effectively reduces postprandial blood glucose excursions in Type 2 diabetic men. $\mathrm{J}$ Nutr 136: 1294-1299.

8. Newsholme, P., Brennan, L., Rubi, B. \& Maechler, P. (2005) New insights into amino acid metabolism, beta-cell function and diabetes. Clin Sci (Lond) 108: 185-194.

9. Jiang, G. \& Zhang, B. B. (2003) Glucagon and regulation of glucose metabolism. Am J Physiol Endocrinol Metab 284: E671-678.

10. Kabadi, U. M. (1991) Dose-kinetics of pancreatic alpha- and beta-cell responses to a protein meal in normal subjects. Metabolism 40: 236-240.

11. Perea, A., Clemente, F., Martinell, J., Villanueva-Penacarrillo, M. L. \& Valverde, I. (1995) Physiological effect of glucagon in human isolated adipocytes. Horm Metab Res 27: 372-375.

12. Carlson, M. G., Snead, W. L. \& Campbell, P. J. (1993) Regulation of free fatty acid metabolism by glucagon. J Clin Endocrinol Metab 77: 11-15.

13. Calbet, J. A. \& MacLean, D. A. (1997) Role of caloric content on gastric emptying in humans. J Physiol 498 ( Pt 2): 553-559.

14. WHO (2000) Obesty: Preventing and managing the global epidemic, Geneva.

15. Zo eet Nederland, 1998. Resultaten van de Voedselconsumptiepeiling 1997-1998. Den Haag. Voedingscentrum 1998. Drukkerij ten Brink.

16. van Eijk, H. M., Rooyakkers, D. R. \& Deutz, N. E. (1993) Rapid routine determination of amino acids in plasma by high-performance liquid chromatography with a 2-3 microns Spherisorb ODS II column. J Chromatogr 620: 143-148.

17. Leclercq-Meyer, V., Marchand, J. \& Malaisse, W. J. (1976) The role of calcium in glucagon release. Interactions between arginine and calcium. Horm Res 7: 348-362.

18. van Hall, G., Shirreffs, S. M. \& Calbet, J. A. (2000) Muscle glycogen resynthesis during recovery from cycle exercise: no effect of additional protein ingestion. J Appl Physiol 88: 1631-1636. 
19. Claessens, M., Calame, W., Siemensma, A. D., Saris, W. H. M. \& van Baak, M. A. (2007) The thermogenic and metabolic effect of protein hydrolysate with or without a carbohydrate load in healthy male subjects. Metabolism 56: 1051-1059.

20. Calbet, J. A. \& Holst, J. J. (2004) Gastric emptying, gastric secretion and enterogastrone response after administration of milk proteins or their peptide hydrolysates in humans. Eur J Nutr 43: 127-139.

21. Lacroix, M., Bos, C., Leonil, J., Airinei, G., Luengo, C., Dare, S., Benamouzig, R., Fouillet, H., Fauquant, J. et al. (2006) Compared with casein or total milk protein, digestion of milk soluble proteins is too rapid to sustain the anabolic postprandial amino acid requirement. Am J Clin Nutr 84: 1070-1079.

22. Baro, L., Guadix, E. M., Martinez-Augustin, O., Boza, J. J. \& Gil, A. (1995) Serum amino acid concentrations in growing rats fed intact protein versus enzymatic protein hydrolysate-based diets. Biol Neonate 68: 55-61.

23. Boza, J. J., Martinez-Augustin, O., Baro, L., Suarez, M. D. \& Gil, A. (1995) Protein v. enzymic protein hydrolysates. Nitrogen utilization in starved rats. Br J Nutr 73: 65-71.

24. Bolea, S., Pertusa, J. A., Martin, F., Sanchez-Andres, J. V. \& Soria, B. (1997) Regulation of pancreatic beta-cell electrical activity and insulin release by physiological amino acid concentrations. Pflugers Arch 433: 699-704.

25. Hermans, M. P., Schmeer, W. \& Henquin, J. C. (1987) The permissive effect of glucose, tolbutamide and high $\mathrm{K}+$ on arginine stimulation of insulin release in isolated mouse islets. Diabetologia 30: 659665 .

26. Smith, P. A., Sakura, H., Coles, B., Gummerson, N., Proks, P. \& Ashcroft, F. M. (1997) Electrogenic arginine transport mediates stimulus-secretion coupling in mouse pancreatic beta-cells. J Physiol 499 ( Pt 3): 625-635.

27. Rocha, D.M., Faloona, G. R. \& Unger, R. H. (1972) Glucagon-stimulating activity of 20 amino acids in dogs. J Clin Invest 51: 2346-2351. 


\section{Chapter 3}

\section{Glucagon and insulin responses after ingestion of different amounts of intact and hydrolysed proteins}

Mandy Claessens, Wim HM Saris, Marleen A van Baak

Nutrition and Toxicology Research Institute Maastricht (NUTRIM), Department of Human Biology, Maastricht University, Maastricht, The Netherlands

This work was supported by Kerry Bio-Science, Almere, The Netherlands

Based on: British Journal of Nutrition, 2007 (in press) 


\begin{abstract}
Ingestion of dietary protein is known to induce both insulin and glucagon secretion. These responses may be affected by the dose and the form (intact or hydrolysed) in which protein is ingested. The aim of the study was to investigate the effect of different amounts of intact protein and protein hydrolysate of a vegetable (soy) and animal (whey) protein on insulin and glucagon responses and to study the effect of increasing protein loads for both intact protein and protein hydrolysate in man. The study employed a repeated measures design with Latin square randomization and single-blind trials. Twelve healthy non-obese males ingested three doses $(0.3,0.4$ and $0.6 \mathrm{~g} / \mathrm{kg} \mathrm{BW})$ of intact soy protein (SPI) and soy protein hydrolysate (SPH). Another group of 12 healthy male subjects ingested 3 doses $(0.3,0.4$ and $0.6 \mathrm{~g} / \mathrm{kg} \mathrm{BW})$ of intact whey protein (WPI) and whey protein hydrolysate (WPH). Blood was sampled before $(\mathrm{t}=0)$ and 15, 30, 60, 90 and $120 \mathrm{~min}$ after protein ingestion for insulin, glucagon and glucose determination. SPI induced a higher total AUC for insulin and glucagon than SPH while no difference between WPI and WPH was found. Insulin and glucagon responses increased with increasing protein load for SPI, SPH, WPI and WPH, but the effect was more pronounced for glucagon. A higher dose of protein or its hydrolysate will result in a lower insulin:glucagon ratio, an important parameter for the control of postprandial substrate metabolism. In conclusion, insulin and glucagon responses were protein and hydrolysate specific.
\end{abstract}




\section{Introduction}

Dietary proteins are well known to induce insulin secretion both with and without carbohydrate co-ingestion in healthy (1-7) and diabetic subjects $(8,9)$. Dietary proteins are also found to induce glucagon secretion $(5,7,10,11)$. The balance between the insulin and glucagon response is important for the regulation of postprandial substrate oxidation $(12,13)$ and also plays a role in cholesterol metabolism (14-16). It is therefore interesting to know how this ratio can be affected by the type and dose of a protein and its form (intact or hydrolysed). We have demonstrated previously that the magnitude of the glucagon response varies more with the protein type than the magnitude of the insulin response does, which was influenced more by carbohydrate co-ingestion (17). Spiller et al (18) and Kabadi (19) have looked at the effect of protein dose on insulin and/or glucagon secretion previously. In the former study the effect of a protein range between 0 and $49.9 \mathrm{~g}$ absolute protein with a carbohydrate load of $58 \mathrm{~g}$ on plasma insulin was tested. The protein source was a mixture of intact milk and soy protein (18). Kabadi, on the other hand, studied the effect of 0.25 to $2 \mathrm{~g} / \mathrm{kg} \mathrm{BW}$ protein hydrolysate of which the composition and degree of hydrolysis was not clearly stated on insulin and glucagon secretion (19). While Kabadi found that insulin secretion was more affected by amount of protein hydrolysate than glucagon secretion, Spiller and colleagues did not find a clear effect of protein dose on insulin secretion (18). Whether this difference is due to the protein form, protein source or due to co-ingestion of carbohydrates is not clear. Proteins can be ingested as intact protein, protein hydrolysates or as free amino acids. A faster increase in plasma amino acids after consumption of protein hydrolysate compared to intact protein has been suggested for casein, but not for proteins from other sources like whey protein (7). Protein hydrolysates containing mainly di-, tri- and tetrapeptides have also been found to be absorbed faster than free amino acid mixtures of the same composition both in rats (20) and humans (21). Furthermore, the chain length of peptides has an important influence on the absorption rate of partially hydrolysed proteins (21). Short peptides containing two and three amino acids, can be absorbed by specific PEPT1 transporters and be hydrolysed intracellularly after absorption (21-23). Some of these short peptides may escape intracellular hydrolysis, since recently low concentrations of circulating bioactive di- and tri-peptides have been reported (24).

In addition, protein source has also been found to influence the absorption rate. This has led to the grouping of proteins into fast and slow digestible proteins $(4,11,25,26)$. In this regard, fast digestible proteins are soluble and ingested/absorbed fast, while slow digestible proteins clot in the stomach and lead to a slower gastric emptying and intestinal absorption (25). 
Little is known about the effect of protein fractionation on hormonal and metabolic responses and how these effects are influenced by the source of protein. Previously, van Loon and colleagues recommended the use of protein hydrolysate rather than intact protein to stimulate insulin secretion because protein hydrolysate consumption resulted in a faster increase in plasma amino acid concentrations (1). However, this recommendation is based on comparison of responses to intact protein (casein) and protein hydrolysates (whey, pea and wheat) from different sources.

The aim of the present study was to investigate the responses of glucagon and insulin to ingestion of different amounts of intact and hydrolysed proteins. Soy and whey protein were chosen as examples of a fast vegetable (27) and a fast animal protein (25).

\section{Subjects and Methods}

\section{Subjects}

Twenty-four healthy non-obese male subjects participated in this study. Twelve subjects participated in the trials in which soy protein and its hydrolysate were tested (age $28 \pm$ 2.9 year, weight $72.2 \pm 2.8 \mathrm{~kg}$, height $1.82 \pm 0.04 \mathrm{~m}$, BMI $24.0 \pm 0.9 \mathrm{~kg} / \mathrm{m}^{2}$; means \pm SEM) and another 12 subjects participated in the trials in which whey protein and its hydrolysate were tested (age $23.8 \pm 1.3$ year, weight $79.8 \pm 2.6 \mathrm{~kg}$, height $1.89 \pm 0.03$ $\mathrm{m}$, BMI $22.0 \pm 0.4 \mathrm{~kg} / \mathrm{m}^{2}$ ). All subjects were informed about the nature and risks of the experimental procedures and informed consent was obtained. The local Medical Ethical Committee approved the study.

\section{Experimental design}

The study consisted of 2 sets of 6 trials. In the first set of trials intact soy protein (SPI) and soy protein hydrolysate $(\mathrm{SPH})$ were tested in 3 concentrations each $(0.3 \mathrm{~g} / \mathrm{kg}$ body weight (BW), $0.4 \mathrm{~g} / \mathrm{kg} \mathrm{BW}$ and $0.6 \mathrm{~g} / \mathrm{kg} \mathrm{BW}$; caloric density $1.2,1.6$ and $2.4 \mathrm{kcal} / \mathrm{kg}$ $\mathrm{BW}$, respectively). In the second set of trials intact whey protein (WPI) and whey protein hydrolysate (WPH) were tested in the same 3 concentrations. In both sets of trials subjects consumed all 6 drinks in random order (by means of Latin square randomisation). All protein and hydrolysate beverages were sweetened with aspartame and the $\mathrm{pH}$ of all beverages was adjusted $\mathrm{pH} 3.3$ - 3.5 in a standard way with citric acid. Protein hydrolysates were made via an enzymatic procedure and the molecular weight profiles of both hydrolysates are depicted in Table 3.1. The amino acid composition of the hydrolysates was determined by HPLC analysis (Lithium system, Jeol Inc., Tokyo, Japan) of free amino acids after precipitation of large peptides/proteins and compared to results of standard samples. 
Table 3.1 Molecular weight profiles of soy and whey protein hydrolysate

\begin{tabular}{lll}
\hline Molecular weight & Soy protein hydrolysate & Whey protein hydrolysate \\
\hline$\leq 1 \mathrm{kDa}$ & $77 \%$ & $82 \%$ \\
$>1 \mathrm{kDa}$ and $<5 \mathrm{kDa}$ & $14 \%$ & $16 \%$ \\
$\geq 5 \mathrm{kDa}$ & $4 \%$ & $7 \%$ \\
\hline
\end{tabular}

Amino acid profiles of the different test drinks are given in Table 3.2. SPI and SPH beverages were uniformly vanilla flavoured, while WPI and WPH beverages were uniformly chocolate flavoured. Since both flavours did not contain any carbohydrates or other energy containing ingredients, addition of the flavours did not add carbohydrates or energy to the test drinks. Beverages $( \pm 250 \mathrm{ml})$ were offered in opaque drinking bottles in order to obtain single-blind trials. Testing days were separated by at least 2 days. At testing days, subjects came to the lab after an overnight fast and were asked to avoid heavy physical activity the day before the trials and to keep their eating pattern as constant as possible.

Table 3.2 Amino acid composition of soy and whey protein (hydrolysate)

\begin{tabular}{lcc}
\hline Amino acids & Soy & Whey \\
\hline Aspartic acid (Asx)* & 12.1 & 11.0 \\
Serine (Ser) & 5.2 & 5.7 \\
Glutamic Acid (Glx)* & 19.7 & 18.6 \\
Histidine (His) & 2.5 & 1.8 \\
Glycine (Gly) & 4.3 & 1.8 \\
Threonine (Thr) & 3.9 & 7.4 \\
Arginine (Arg) & 7.4 & 2.3 \\
Alanine (Ala) & 4.4 & 5.3 \\
Tyrosin (Tyr) & 3.1 & 2.6 \\
Valine (Val) & 3.9 & 5.1 \\
Methione (Met) & 1.2 & 1.5 \\
Isoleucine (Ile) & 3.7 & 5.7 \\
Phenylalanine (Phe) & 4.9 & 2.7 \\
Tryptophan (Trp) & 1.3 & 1.4 \\
Leucine (Leu) & 7.5 & 9.8 \\
Lysine (lys) & 6.6 & 9.5 \\
Proline (Pro) & 6.4 & 6.6 \\
Cysteine (Cys) & 2.2 & 1.4 \\
\hline Values expressed as percentage of total & & \\
\hline
\end{tabular}

Values expressed as percentage of total dry product

*Asx: Asparagine + Aspartic acid; Glx: glutamate + glutamine

\section{Protocol}

After at least 10 hours fasting, subjects reported to the laboratory where a Teflon catheter (Baxter BV, Utrecht, The Netherlands) was inserted into an antecubital vein 
and a resting blood sample was drawn $(\mathrm{t}=0)$. Then subjects were offered the test drink, which they had to consume as quickly as possible within 5 minutes. Blood samples were drawn 15, 30, 60, 90 and 120 minutes after finishing the test drink.

\section{Blood analyses}

Blood was collected in EDTA containing tubes for glucose, insulin, glucagon, lactate and urea analysis. EDTA blood to which aprotinin $(5 \mathrm{kIU} / \mathrm{ml}$ blood; Sigma-Aldrich Chemie BV) was added was used for glucagon analysis. After collection the blood sample was centrifuged at $1000 \mathrm{~g}$ at $4^{\circ} \mathrm{C}$ for $10 \mathrm{~min}$. Aliquots of plasma were frozen immediately in liquid nitrogen and stored at $-45^{\circ} \mathrm{C}$. Glucose, lactate and urea were analysed with the COBAS FARA semi automatic analyser (Roche Diagnostica, Basel, Switzerland). Insulin was analysed by radioimmunoassay (Human Insulin Specific RIA kit, LINCO, Missouri, USA) as was glucagon (Glucagon RIA kit, LINCO, Missouri, USA).

\section{Statistics}

All data are expressed as means \pm SEM ( $n=12$ for both groups). Plasma glucose, insulin, glucagon, lactate and urea responses were calculated as total area under the curve (AUC) (AUC above - AUC below baseline). Statistical analyses were performed by using SPSS for Mac OS X software (SPSS Inc., Chicago, IL). To analyse whether intact protein induced different responses (as total AUC) than protein hydrolysates a mixed design ANOVA was used with protein form (intact, hydrolysate: 2 levels) and amount of protein $(0.3,0.4,0.6 \mathrm{~g} / \mathrm{kg} \mathrm{BW}: 3$ levels $)$ as within-subject factors and protein form $\mathrm{x}$ amount of protein as interaction term. When these tests revealed that protein form or amount of protein induced significantly different total AUCs regarding insulin, glucagon, glucose, lactate or urea more extensive mixed design ANOVA analyses were used to determine at what time point differences were situated. In these extended analyses amount of protein was included in the model as between-subject variable, with protein form (2 levels) and time (0, 15, 30, 60, 90, 120 min: 6 levels) as within-subject factors.

To analyse the effect of ingestion of different amounts of protein/protein hydrolysate on hormonal and metabolic responses a mixed design ANOVA was used with amount of protein ( 3 levels) and time (6 levels) as within-subject factors and amount of protein $\mathrm{x}$ time as interaction term. Protein form was inserted in the model as between-subject variable. At a p-level of 0.05 or smaller results were considered significantly different. 


\section{Results}

\section{Intact protein versus protein hydrolysate}

\section{Soy protein}

Mixed design analysis showed that SPI induced significantly higher total AUC for insulin than SPH $(\mathrm{p}=0.018)$ (Figure 3.1). Further analyses revealed that the difference over time between SPI and SPH was due to a difference in the initial rise in insulin concentrations (Figure 3.2). No significant interaction terms were found. Total AUC for glucagon was also significantly higher after SPI compared to SPH ( $p<0.001$ ) (Figure 3.1) while the interaction between protein form and amount of protein was not significant $(\mathrm{p}=0.196)$. Further analyses showed that, like for insulin, SPI induced a faster increase in glucagon compared to SPH (Figure 3.2). With respect to total AUC for glucose no overall effect of protein form was found for soy $(p=0.146)$

\section{Whey protein}

In case of whey protein no significant difference regarding total AUC for insulin between WPI and WPH was found $(\mathrm{p}=0.754)$ (Figure 3.1). Also total AUC for glucagon was not significantly different between WPI and WPH $(p=0.249)$ but the interaction between protein form and amount of protein was significant $(p=0.002)$ showing that total AUC for glucagon increased significantly more with increasing protein amount after WPH than WPI ( $p=0.004$ for 0.3 vs $0.4 \mathrm{~g} / \mathrm{kg} \mathrm{BW;} \mathrm{p}=0.001$ for $0.3 \mathrm{vs} 0.6 \mathrm{~g} / \mathrm{kg} \mathrm{BW}$ and $\mathrm{p}=0.560$ for $0.4 \mathrm{vs} 0.6 \mathrm{~g} / \mathrm{kg} \mathrm{BW})$. With respect to total AUC for glucose no overall effect of protein form was found $(p=0.980)$. 

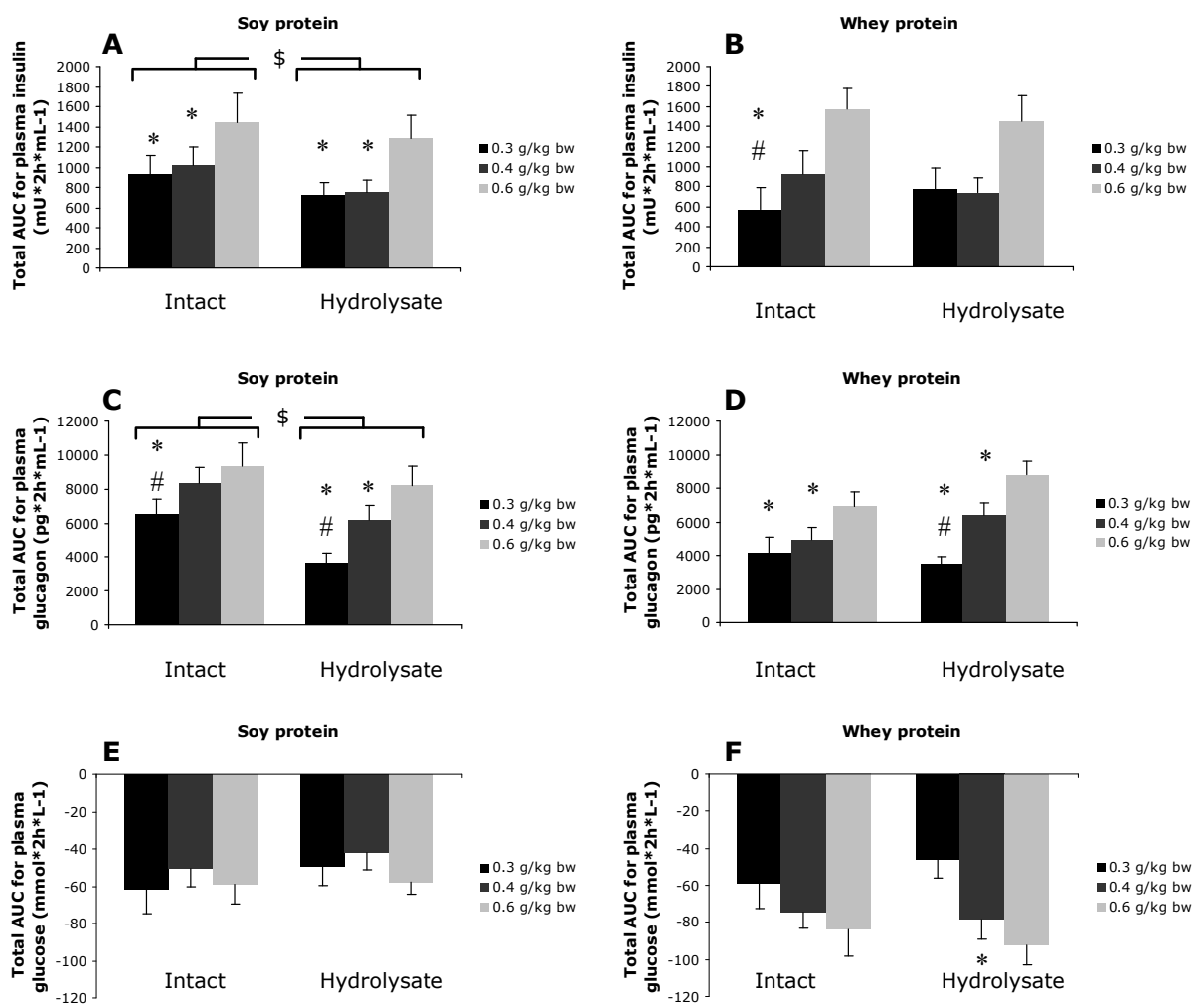

Figure 3.1

Total AUC for insulin, glucagon and glucose after ingestion of $0.3,0.4$ or $0.6 \mathrm{~g} / \mathrm{kg} \mathrm{BW}$ intact protein or protein hydrolysate with soy (A, C and E) or whey as protein source (B, D and F). Values are means $\pm \mathrm{SEM}$. *, significantly different from $0.6 \mathrm{~g} / \mathrm{kg} \mathrm{BW}$; \#, significantly different from $0.4 \mathrm{~g} / \mathrm{kg} \mathrm{BW}$; , significantly different from the hydrolysed protein (independent of protein load). 

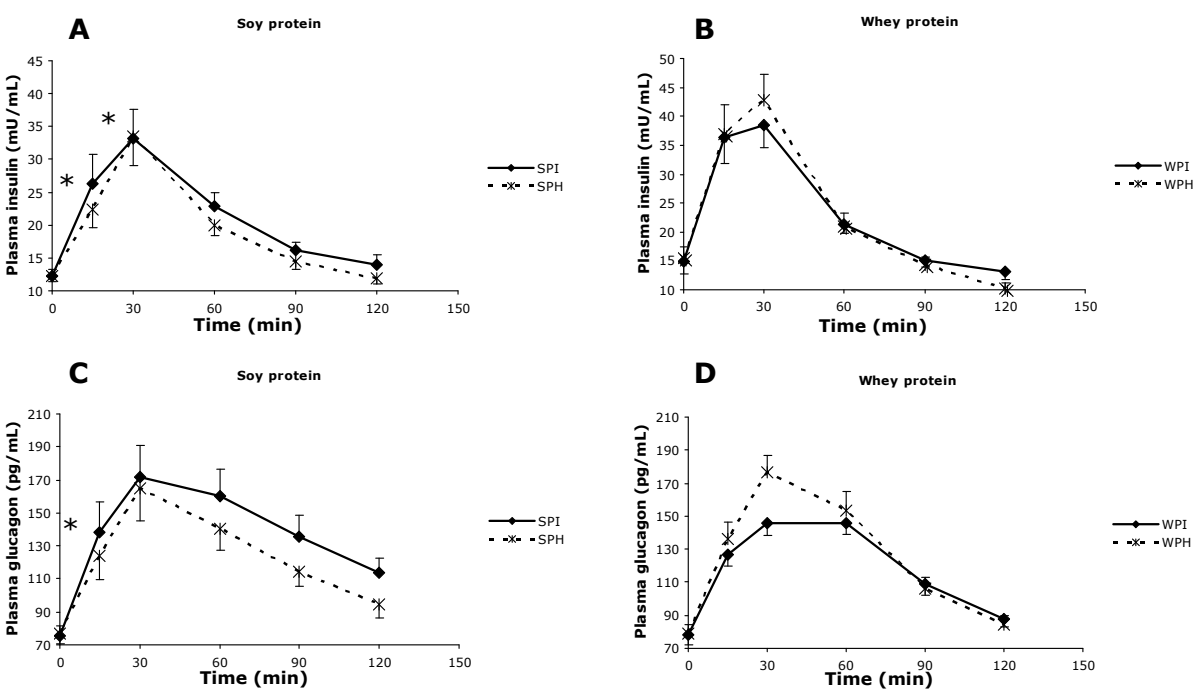

D
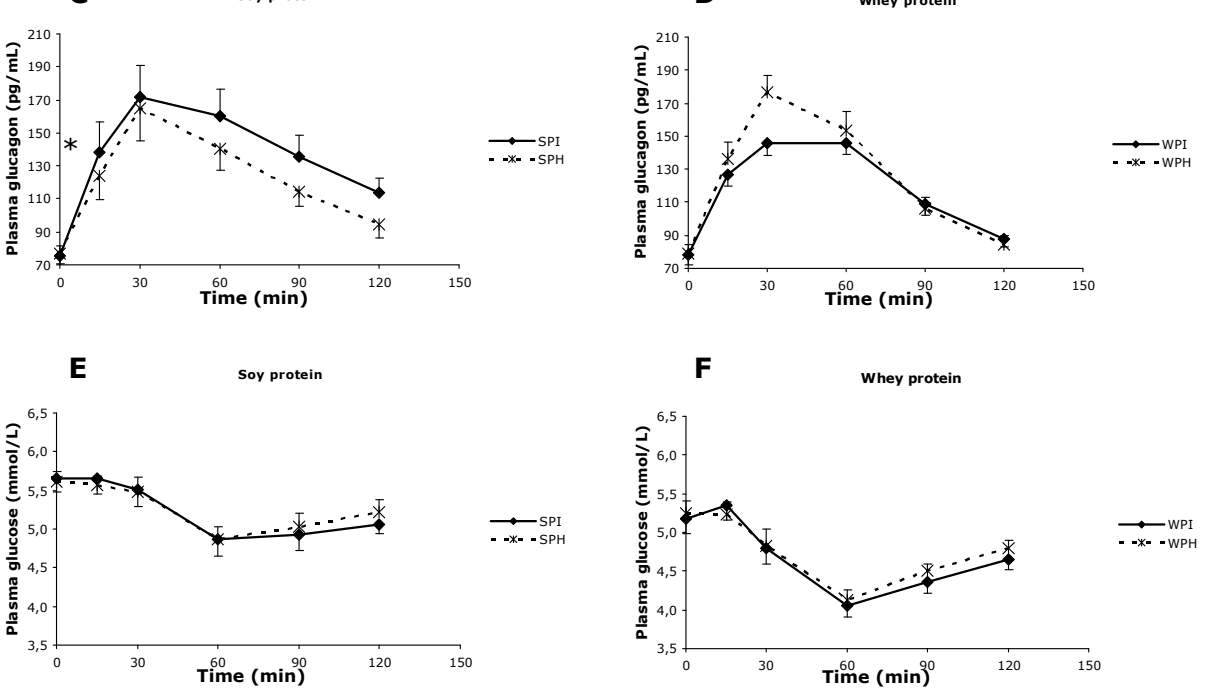

Figure 3.2

Insulin, glucagon and glucose responses after ingestion of intact and hydrolysed soy (A, C and E, respectively) or whey protein $(B, D$ and $F$, respectively). Values are means \pm SEM. *, significantly different slope from the corresponding hydrolysed protein.

\section{Dose-response effect of proteins/protein hydrolysates}

\section{Soy protein}

The overall test of mixed design ANOVA analysis showed that there was a significant increase in total AUC for insulin with increasing amount of soy protein $(p=0.001)$ (Figure 3.1). Further analyses showed that, for SPI, amount of protein and time induced both significant differences in insulin responses $(\mathrm{p}=0.031$ and $\mathrm{p}<0.001$, respectively). The interaction between amount of protein and time was not significant $(p=0.262)$ showing that the pattern of insulin changes over time were not significantly influenced by the amount of protein (Figure 3.3). Tests of within-subject contrasts showed that differences were present between 0.3 and $0.6 \mathrm{~g} / \mathrm{kg} \mathrm{BW} \mathrm{SPI}(\mathrm{p}=0.011)$ and between 0.4 and $0.6 \mathrm{~g} / \mathrm{kg}$ BW SPI $(\mathrm{p}=0.041)$ but not between 0.3 and $0.4 \mathrm{~g} / \mathrm{kg} \mathrm{BW}(\mathrm{p}=0.963)$ (Figure 3.1). In case of SPH, similar results were found $(\mathrm{p}=0.022, \mathrm{p}=0.05$ and $\mathrm{p}=$ 
0.897, respectively). The interaction term amount of protein $\mathrm{x}$ time for SPH was also significant $(\mathrm{p}=0.010)$ with the difference being that a higher protein load mainly resulted in a faster rise in plasma insulin but in general also in a slower decrease (Figure 3.3C).

The overall test for total AUC for glucagon was also significant $(\mathrm{p}<0.001)$ (Figure 3.1) and further analysis over time showed that both for SPI and SPH the effects of protein amount $(\mathrm{p}<0.01)$, time $(\mathrm{p}<0.001)$ and protein amount $\mathrm{x}$ time $(\mathrm{p}<0.001)$ were significant. Tests of within-subject contrasts showed that differences for both SPI and SPH were found between 0.3 and $0.4 \mathrm{~g} / \mathrm{kg} \mathrm{BW}(\mathrm{p}<0.05)$; and 0.3 and $0.6 \mathrm{~g} / \mathrm{kg} \mathrm{BW}$ (p $<0.01$ ); and only for SPH between 0.4 and $0.6 \mathrm{~g} / \mathrm{kg} \mathrm{BW}(\mathrm{p}=0.05)$ (Figure 3.1). Figure 3.4A and $\mathrm{C}$ shows that consumption of increasing amounts of soy protein did not affect the initial rise in plasma glucagon significantly but ingestion of $0.6 \mathrm{~g} / \mathrm{kg} \mathrm{BW} \mathrm{SPI}$ and SPH induced a sustained increase in plasma glucagon.

Analysis of total AUC for glucose showed no significant differences with increasing protein loads.

\section{Whey protein}

Also for whey protein, increasing amounts of protein induced significantly higher total AUCs for insulin $(\mathrm{p}<0.001)$ (Figure 3.1). Further analysis showed that for WPI insulin responses were significantly higher after 0.4 and $0.6 \mathrm{~g} / \mathrm{kg} \mathrm{BW}$ compared to $0.3 \mathrm{~g} / \mathrm{kg} \mathrm{BW}$ WPI ( $p=0.002$ and $p=0.001)$ but not between 0.4 and $0.6 \mathrm{~g} / \mathrm{kg} \mathrm{BW}$ WPI $(\mathrm{p}=0.060)$ (Figure 3.1 and 3.3B). The interaction term amount of protein $\mathrm{x}$ time was also significant for WPI $(\mathrm{p}=0.007)$ with the difference being that a higher protein load mainly resulted in a faster rise in plasma insulin but in general also in a slower decrease. No significant effect of amount of protein was found for WPH ( $p=0.064$ for the overall test). 
A

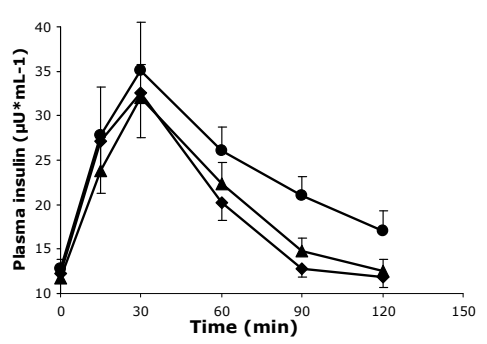

C

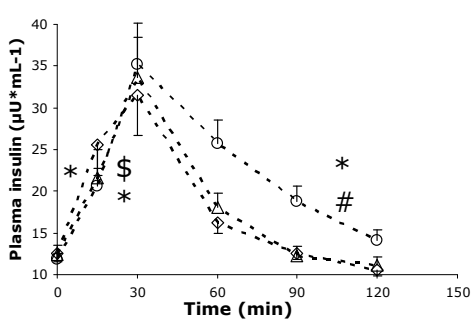

B

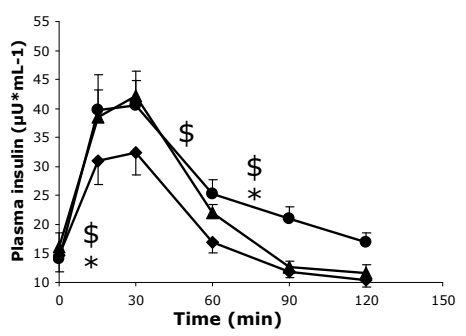

D

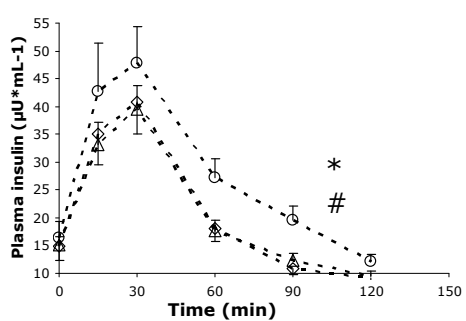

- intact protein 0.3

$\leftarrow$ intact protein 0.4 $\mathrm{g} / \mathrm{kg}$ bw

intact protein 0.6

Figure 3.3

Insulin responses with increasing protein dose for SPI (A), WPI (B), SPH (C) and WPH (D). Values are means \pm SEM. *, significantly different slope for 0.3 vs $0.6 \mathrm{~g} / \mathrm{kg}$ BW protein; $\$$, significantly different slope for $0.3 \mathrm{vs} 0.4 \mathrm{~g} / \mathrm{kg} \mathrm{BW}$ protein; \#, significantly different slope for $0.4 \mathrm{vs} 0.6 \mathrm{~g} / \mathrm{kg} \mathrm{BW}$ protein.

The overall test for total AUCs for glucagon was also significant for whey protein $(\mathrm{p}<$ 0.001 in both cases) (Figure 3.1). Figure 3.4B shows that, like for soy protein, consumption of increasing amounts of intact protein did not affect the initial rise in plasma glucagon significantly but ingestion of $0.6 \mathrm{~g} / \mathrm{kg}$ BW WPI induced a sustained increase in plasma glucagon. Ingestion of increasing amounts of WPH did result in a faster rise in plasma glucagon after 0.6 versus $0.3 \mathrm{~g} / \mathrm{kg} \mathrm{BW}$ WPH but also in a faster decrease between 90 and 120 min after consumption (Figure 3.4D). 

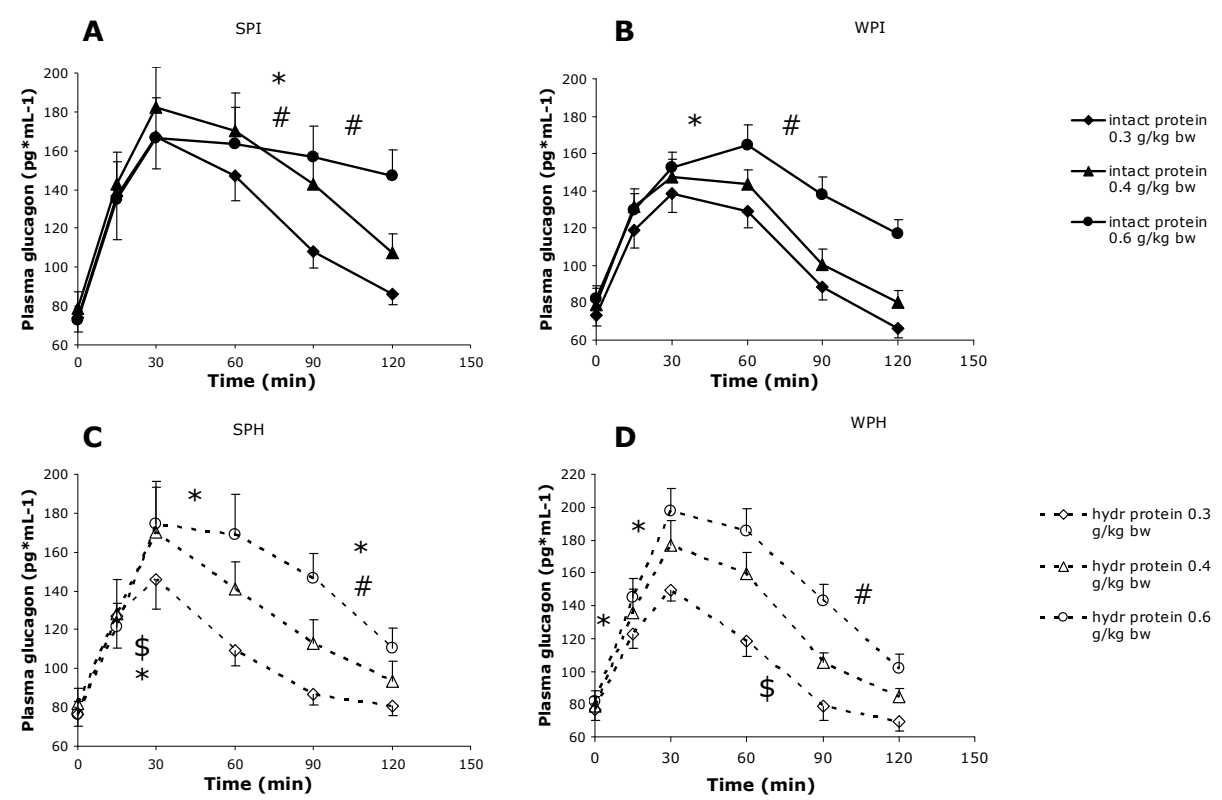

Figure 3.4

Glucagon responses with increasing protein dose for SPI (A), WPI (B), SPH (C) and WPH (D). Values are means \pm SEM. *, significantly different slope for $0.3 \mathrm{vs} 0.6 \mathrm{~g} / \mathrm{kg} \mathrm{BW}$ protein; $\$$, significantly different slope for $0.3 \mathrm{vs} 0.4 \mathrm{~g} / \mathrm{kg} \mathrm{BW}$ protein; \#, significantly different slope for $0.4 \mathrm{vs} 0.6 \mathrm{~g} / \mathrm{kg}$ BW protein.

Analysis of total AUC for glucose showed that for whey protein total AUC for glucose significantly decreased with increasing protein loads $(\mathrm{p}=0.001)$ (Figure 3.1) although the overall test for analysis of patterns over time did not reach significance $(\mathrm{p}=0.054$, Figure 3.5). 

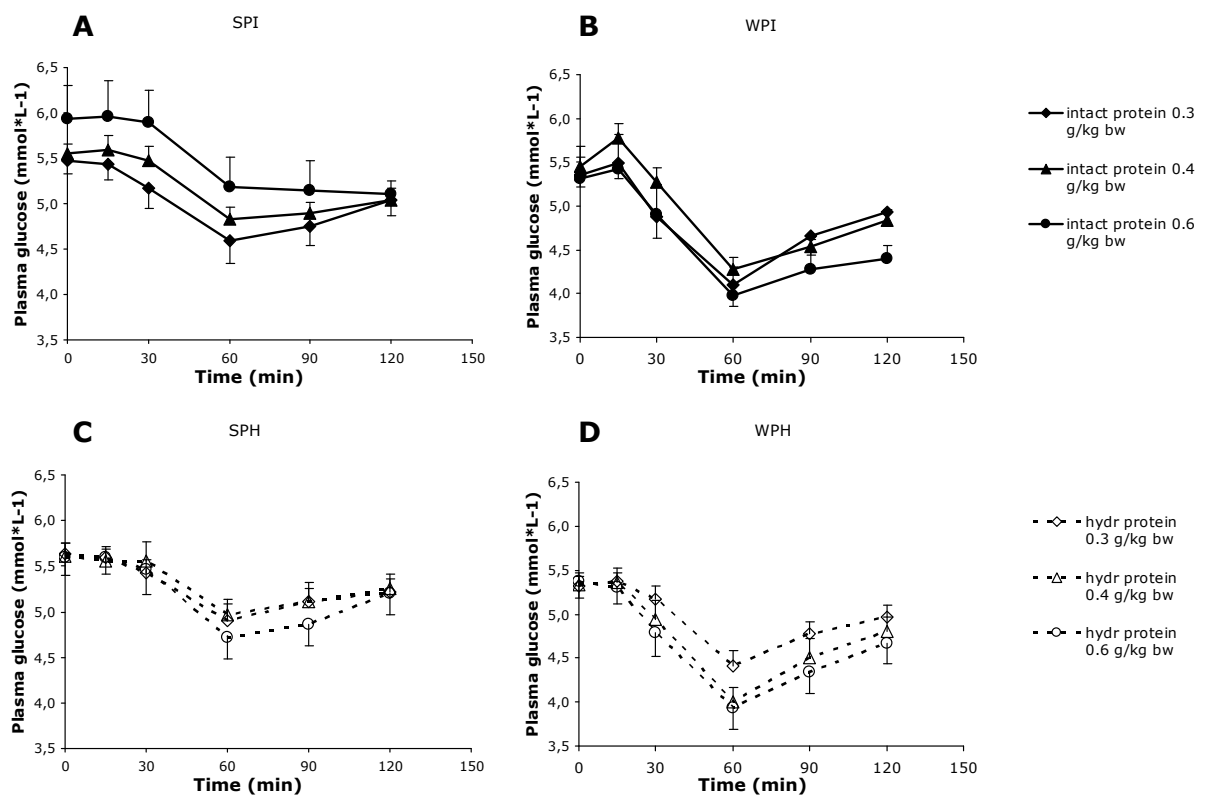

Figure 3.5

Glucose responses with increasing protein dose for SPI (A), WPI (B), SPH (C) and WPH (D). Values are means \pm SEM. No significant differences between different concentrations of SPI, SPH, WPI or WPH as determined by repeated-measures ANOVA analysis

\section{Discussion}

In the present study ingestion of intact soy protein was found to result in a more rapid increase in insulin and glucagon concentrations than ingestion of its hydrolysed form, while no significant differences were found for whey protein. Furthermore, glucagon responses increased with protein load in a dose-dependent way for both intact soy and whey protein and their hydrolysates. Insulin concentration appeared to be less influenced by protein load than glucagon.

\section{Intact protein versus protein hydrolysate}

A fast vegetable (soy protein (27)) and a fast animal protein (whey protein (25)) were studied. We expected for both proteins that protein hydrolysates would induce faster insulin and glucagon responses than intact protein, because di- and tri-peptides are efficiently taken up and further hydrolysed into free amino acids by enterocytes $(22,23$, 28, 29). Calbet and Holst reported more rapid increases in plasma amino acid concentrations after ingestion of hydrolysates (7). Caloric density, rather than solute osmolality, affects gastric emptying $(6,30)$. Although we did not measure plasma amino acid profiles, this would suggest that the gastric emptying rate for an intact protein and 
protein hydrolysate at similar protein dose should be similar. This might not be the case for proteins that, in their intact form, clot in the stomach and in this way delay gastric emptying. Because of that feature, these proteins might be digested and absorbed more slowly. Until now, the only protein known to form clots in the stomach is casein. As might be expected, the more rapid increase in plasma amino acids after consumption of the hydrolysed versus intact protein in humans, has only been described for casein (7). In contrast to our hypothesis, SPI induced a faster increase in both insulin and glucagon, which resulted in significantly higher total AUC after SPI than SPH. However the size of the difference between SPI and SPH is small and is unlikely to be of physiological significance. In case of whey protein, no significant difference in insulin or glucagon response, expressed as total AUC, was found, which is in agreement with the study of Calbet and Holst (7). The molecular weight profiles of SPH and WPH were similar showing that in theory similar amounts of di- and tri-peptides should have been present in both types of hydrolysates. The observation that both protein hydrolysates contained similar amounts of free amino acids (3\% and $2.5 \%$ of $\mathrm{WPH}$ and $\mathrm{SPH}$, respectively) supports this assumption. Although we do not have a clear explanation for the more rapid response in SPI compared to SPH it could be that soy protein is metabolised in a different way than whey protein. It has been reported that the biological value of soy protein is inferior to that of casein (27). The biological value of whey protein has not been studied as extensively as that of soy protein and casein. The protein quality is thought to be dependent on the degree and velocity by which the protein is digested, absorbed as amino acids, and retained in the gut as newly synthesised protein (27). Intact soy protein seems to be ingested and absorbed by the splanchnic area rapidly and also degraded rapidly in the liver into urea, resulting in reduced uptake by the peripheral tissues (like skeletal muscle) $(27,31,32)$. It is possible that consumption of partly hydrolysed soy protein results in an even faster absorption of free amino acids and in an even more reduced uptake by peripheral organs. When amino acids are rapidly removed from circulation, their insulin and glucagon stimulating capacity might be reduced. Although this hypothesis should be studied more carefully, this might explain why for soy protein the intact form induced faster insulin and glucagon responses than its hydrolysed form.

\section{Dose-response effect of intact protein and protein hydrolysates}

The effect of protein dose on insulin or glucagon responses has been studied poorly. In the present study we found a dose-dependent relation between protein load and insulin and glucagon response, although the dose effect was more pronounced for glucagon than for insulin (Figures 1, 3 and 4). Spiller and colleagues studied the effect of increasing intact protein (mixture of milk and soy protein) $(0,15.8,25.1,33.6$ and 49.9 
g) with a constant carbohydrate load ( $\pm 58 \mathrm{~g}$ ) on insulin concentrations (18). This study showed that the protein/carbohydrate mixtures induced significantly higher insulin responses than the carbohydrate load alone, which is similar to previous findings from our group (chapter 2), but they did not find an effect of protein dose. Kabadi (1991) studied the effect of increasing amounts of amino acid mixtures $(0.25,0.5,1$ and $2 \mathrm{~g} / \mathrm{kg}$ BW) without carbohydrates on both insulin and glucagon secretion (19). This study did find a dose-dependent increase of insulin and glucagon concentrations, in agreement with our study, although in their study insulin was affected more by protein load than glucagon (19). The fact that Spiller and colleagues did not find a dose effect on insulin is unlikely to be due to the dose range studied, which was similar to ours. An explanation could be that the maximal capacity for insulin secretion by pancreatic $\beta$ cells was reached already when the lowest amount of protein was co-ingested with the carbohydrate load (18).

Furthermore, we found that glucagon responses were more dependent on protein load and that this effect was more pronounced for the hydrolysed proteins as compared to the intact proteins. This is also in agreement with the observation of Rérat and colleagues who reported that, in pigs, insulin production was less influenced by amount of protein than glucagon production (28). Consumption of increasing amounts of proteins will cause higher concentrations of plasma amino acids, which are associated with higher plasma glucagon levels (5). Kabadi, on the other hand, suggested the opposite (19). The much higher protein amounts used by Kabadi could explain these conflicting findings. As Kabadi suggested already, the increase in plasma glucagon may have reached a plateau with the protein meal of $1 \mathrm{~g} / \mathrm{kg}$ BW (19). Since our highest protein load was far below $1 \mathrm{~g} / \mathrm{kg}$ BW this might explain why in the present study we did find a dosedependent increase in plasma glucagon concentrations. Because proteins are generally not very tasteful, especially when hydrolysed, and difficult to dissolve, we have chosen a maximum protein load of $0.6 \mathrm{~g} / \mathrm{kg}$ BW. Furthermore, this dose might still be applicable for practical use. Like in our study, though, Kabadi also found sustained glucagon concentrations over 3 hours after ingestion (19). The prolonged stimulation of glucagon might be due to the fall in glucose concentrations after protein consumption due to the protein-induced insulin response. Therefore, differences in glucagon responses to different protein loads might be indirectly enlarged by insulin-induced reductions in glucose concentrations.

It has previously been demonstrated that, when proteins and carbohydrates are coingested, the effect on insulin concentrations are synergistic $(5,17)$. If and at which dosages a maximal insulin response is reached remains to be investigated. How carbohydrate co-ingestion would affect protein-induced glucagon secretion is likely to 
depend on the carbohydrate dosage, since glucagon secretion is controlled by both plasma amino acids and the change in glucose concentrations (33).

In conclusion, we found that insulin and glucagon concentrations increased more and faster after intact soy protein than after its hydrolysate, while no difference between intact whey protein and its hydrolysate were found. Therefore, no general recommendation with respect to the use of intact protein or hydrolysates to stimulate a rapid insulin and glucagon response can be made because differences between intact protein and its hydrolysate may be protein specific. Although protein hydrolysation did not influence insulin and glucagon responses substantially in the present study, where we tested only fast digestible proteins, it is likely that for casein, a slow digestible protein, the intact protein does induce different hormonal responses than the hydrolysed form.

Within the dose range studied $(0.3-0.6 \mathrm{~g} / \mathrm{kg} \mathrm{BW})$, insulin and glucagon both increased dose-dependently but the effect was more pronounced for glucagon than for insulin.

\section{Acknowledgements}

The studies described in this article, that were performed in the laboratories of the authors, were financially supported by Kerry Bio-Science, Almere, The Netherlands.

The authors would like to thank Dr. W. Calame and Dr. A.D. Siemensma from Kerry Bioscience for their contributions and fruitful discussions. 


\section{References}

1. van Loon, L. J., Saris, W. H., Verhagen, H. \& Wagenmakers, A. J. (2000) Plasma insulin responses after ingestion of different amino acid or protein mixtures with carbohydrate. Am J Clin Nutr 72: 96-105.

2. Westphal, S. A., Gannon, M. C. \& Nuttall, F. Q. (1990) Metabolic response to glucose ingested with various amounts of protein. Am J Clin Nutr 52: 267-272.

3. Krezowski, P. A., Nuttall, F. Q., Gannon, M. C. \& Bartosh, N. H. (1986) The effect of protein ingestion on the metabolic response to oral glucose in normal individuals. Am J Clin Nutr 44: 847-856.

4. Dangin, M., Boirie, Y., Garcia-Rodenas, C., Gachon, P., Fauquant, J., Callier, P., Ballevre, O. \& Beaufrere, B. (2001) The digestion rate of protein is an independent regulating factor of postprandial protein retention. Am J Physiol Endocrinol Metab 280: E340-348.

5. Calbet, J. A. \& MacLean, D. A. (2002) Plasma glucagon and insulin responses depend on the rate of appearance of amino acids after ingestion of different protein solutions in humans. J Nutr 132: 21742182.

6. Calbet, J. A. \& MacLean, D. A. (1997) Role of caloric content on gastric emptying in humans. J Physiol 498 ( Pt 2): 553-559.

7. Calbet, J. A. \& Holst, J. J. (2004) Gastric emptying, gastric secretion and enterogastrone response after administration of milk proteins or their peptide hydrolysates in humans. Eur J Nutr 43: 127-139.

8. Manders, R. J., Wagenmakers, A. J., Koopman, R., Zorenc, A. H., Menheere, P. P., Schaper, N. C., Saris, W. H. \& van Loon, L. J. (2005) Co-ingestion of a protein hydrolysate and amino acid mixture with carbohydrate improves plasma glucose disposal in patients with type 2 diabetes. Am J Clin Nutr 82: 76-83.

9. Manders, R. J., Koopman, R., Sluijsmans, W. E., van den Berg, R., Verbeek, K., Saris, W. H., Wagenmakers, A. J. \& van Loon, L. J. (2006) Co-ingestion of a protein hydrolysate with or without additional leucine effectively reduces postprandial blood glucose excursions in Type 2 diabetic men. $\mathrm{J}$ Nutr 136: 1294-1299.

10. Rocha, D. M., Faloona, G. R. \& Unger, R. H. (1972) Glucagon-stimulating activity of 20 amino acids in dogs. J Clin Invest 51: 2346-2351.

11. Hall, W. L., Millward, D. J., Long, S. J. \& Morgan, L. M. (2003) Casein and whey exert different effects on plasma amino acid profiles, gastrointestinal hormone secretion and appetite. Br J Nutr 89: 239-248.

12. Claessens, M., Calame, W., Siemensma, A. D., Saris, W. H. M. \& van Baak, M. A. (2007) The thermogenic and metabolic effect of protein hydrolysate with or without a carbohydrate load in healthy male subjects. Metabolism 56: 1051-1059.

13. Lejeune, M. P., Kovacs, E. M. \& Westerterp-Plantenga, M. S. (2005) Additional protein intake limits weight regain after weight loss in humans. Br J Nutr 93: 281-289.

14. McCarty, M. F. (1999) Vegan proteins may reduce risk of cancer, obesity, and cardiovascular disease by promoting increased glucagon activity. Med Hypotheses 53: 459-485.

15. Sanchez, A. \& Hubbard, R. W. (1991) Plasma amino acids and the insulin/glucagon ratio as an explanation for the dietary protein modulation of atherosclerosis. Med Hypotheses 36: 27-32.

16. Hubbard, R., Kosch, C. L., Sanchez, A., Sabate, J., Berk, L. \& Shavlik, G. (1989) Effect of dietary protein on serum insulin and glucagon levels in hyper- and normocholesterolemic men. Atherosclerosis 76: 55-61.

17. Claessens, M., Calame, W., Siemensma, A. D., van Baak, M. A. \& Saris, W. H. M. (2007) The effect of different protein hydrolysate/carbohydrate mixtures on postprandial glucagon and insulin responses in healthy subjects. Eur J Clin Nutr (in press). 
18. Spiller, G. A., Jensen, C. D., Pattison, T. S., Chuck, C. S., Whittam, J. H. \& Scala, J. (1987) Effect of protein dose on serum glucose and insulin response to sugars. Am J Clin Nutr 46: 474-480.

19. Kabadi, U. M. (1991) Dose-kinetics of pancreatic alpha- and beta-cell responses to a protein meal in normal subjects. Metabolism 40: 236-240.

20. Poullain, M. G., Cezard, J. P., Roger, L. \& Mendy, F. (1989) Effect of whey proteins, their oligopeptide hydrolysates and free amino acid mixtures on growth and nitrogen retention in fed and starved rats. JPEN J Parenter Enteral Nutr 13: 382-386.

21. Grimble, G. K., Keohane, P. P., Higgins, B. E., Kaminski, M. V., Jr. \& Silk, D. B. (1986) Effect of peptide chain length on amino acid and nitrogen absorption from two lactalbumin hydrolysates in the normal human jejunum. Clin Sci (Lond) 71: 65-69.

22. Smith, M. E. \& Morton, D. G. (2001) The digestive System: system of the body. Elsevier.

23. Daniel, H. (2004) Molecular and integrative physiology of intestinal peptide transport. Annu Rev Physiol 66: 361-384.

24. Foltz, M., Meynen, E. E., Bianco, V., van Platerink, C., Koning, T. M. \& Kloek, J. (2007) Angiotensin converting enzyme inhibitory peptides from a lactotripeptide-enriched milk beverage are absorbed intact into the circulation. J Nutr 137: 953-958.

25. Boirie, Y., Dangin, M., Gachon, P., Vasson, M. P., Maubois, J. L. \& Beaufrere, B. (1997) Slow and fast dietary proteins differently modulate postprandial protein accretion. Proc Natl Acad Sci U S A 94: 14930-14935.

26. Dangin, M., Boirie, Y., Guillet, C. \& Beaufrere, B. (2002) Influence of the protein digestion rate on protein turnover in young and elderly subjects. J Nutr 132: 3228S-3233S.

27. Luiking, Y. C., Deutz, N. E., Jakel, M. \& Soeters, P. B. (2005) Casein and soy protein meals differentially affect whole-body and splanchnic protein metabolism in healthy humans. J Nutr 135: 1080-1087.

28. Rerat, A., Nunes, C. S., Mendy, F. \& Roger, L. (1988) Amino acid absorption and production of pancreatic hormones in non-anaesthetized pigs after duodenal infusions of a milk enzymic hydrolysate or of free amino acids. Br J Nutr 60: 121-136.

29. Sleisenger, M. H. \& Kim, Y. S. (1979) Protein digestion and absorption. N Engl J Med 300: 659-663.

30. Brouns, F., Senden, J., Beckers, E. J. \& Saris, W. H. (1995) Osmolarity does not affect the gastric emptying rate of oral rehydration solutions. JPEN J Parenter Enteral Nutr 19: 403-406.

31. Bos, C., Metges, C. C., Gaudichon, C., Petzke, K. J., Pueyo, M. E., Morens, C., Everwand, J., Benamouzig, R. \& Tome, D. (2003) Postprandial kinetics of dietary amino acids are the main determinant of their metabolism after soy or milk protein ingestion in humans. J Nutr 133: 1308-1315.

32. Fouillet, H., Mariotti, F., Gaudichon, C., Bos, C. \& Tome, D. (2002) Peripheral and splanchnic metabolism of dietary nitrogen are differently affected by the protein source in humans as assessed by compartmental modeling. J Nutr 132: 125-133.

33. Schwartz, N. S., Clutter, W. E., Shah, S. D. \& Cryer, P. E. (1987) Glycemic thresholds for activation of glucose counterregulatory systems are higher than the threshold for symptoms. J Clin Invest 79: 777 781 . 


\section{Chapter 4}

\section{The thermogenic and metabolic effect of protein hydrolysate with or without a carbohydrate load in healthy male subjects}

Mandy Claessens ${ }^{1}$, Wim Calame ${ }^{2}$, André D Siemensma ${ }^{2}$, Wim HM Saris ${ }^{1}$, Marleen A van Baak $^{1}$

Nutrition and Toxicology Research Institute Maastricht (NUTRIM), Department of Human Biology, Maastricht University, Maastricht, The Netherlands ${ }^{1}$; Kerry BioScience, Almere, The Netherlands ${ }^{2}$

This work was supported by Kerry Bio-Science, Almere, The Netherlands

Based on: Metabolism 56: 1051-1059, 2007 


\begin{abstract}
High-protein diets are beneficial in weight maintenance because of their satiating and thermogenic effects. These effects may be partly mediated by the hormonal effects of proteins. This study investigated the effect of soy protein hydrolysate (SPH) with and without a carbohydrate $(\mathrm{CHO})$ pre- and afterload on energy metabolism and hormonal secretion in eight healthy non-obese subjects. In an additional trial pea protein hydrolysate $(\mathrm{PPH})$ was compared with $\mathrm{SPH}$, both with a carbohydrate afterload. The study had a single blind cross-over design. In all cases $0.4 \mathrm{~g}$ protein and/or carbohydrate/kg body weight was tested. Diet-induced thermogenesis (DIT) was measured by ventilated hood measurements and postprandial blood samples were drawn over 3 hours. SPH consumption induced a higher DIT than a CHO load. Both conditions induced similar insulin responses. SPH induced a glucagon but no glucose response while $\mathrm{CHO}$ induced a glucose but no glucagon response. SPH with a CHO pre- or afterload induced similar DIT and insulin responses. No glucose response was found when SPH preceded the CHO load. Total glucagon responses were similar with $\mathrm{CHO}$ as pre- and afterload, but time courses were different. $\mathrm{PPH}$ with a $\mathrm{CHO}$ afterload induced both higher insulin and glucagon responses (AUC) than SPH with $\mathrm{CHO}$ afterload but DIT was similar in both conditions. In conclusion, this study shows that the larger DIT after protein than CHO may be related to the glucagon response that is induced by protein but not by $\mathrm{CHO}$, that the protein-induced DIT and glucagon response is not influenced by a $\mathrm{CHO}$ pre- or afterload and that protein ingestion can fully prevent the plasma glucose increase associated with $\mathrm{CHO}$ when $\mathrm{CHO}$ are ingested after proteins.
\end{abstract}




\section{Introduction}

In obesity research, high-protein diets are of special interest since they induce weight loss $(1,2)$ and reduce weight regain after a period of weight loss (3). This beneficial effect may be due to the satiety-inducing, thermogenic and/or hormonal effects of dietary proteins. Lejeune et al (2006) showed that a 4-day high-protein diet (30 En\% protein) in healthy female subjects increased 24-h satiety, energy expenditure (mainly sleeping metabolic rate and diet-induced thermogenesis) and fat oxidation compared to a low-protein diet (10 En\% protein) (4). Furthermore, a high-protein meal tends to induce higher diet-induced thermogenesis (DIT) compared to a fat or carbohydrate meal with similar energy density $(5,6)$. The underlying mechanisms remain unclear. Proteins stimulate insulin secretion by pancreatic $\beta$-cells $(7,8)$ and induce glucagon secretion by pancreatic $\alpha$-cells $(8,9)$. The most studied function of glucagon is its counterregulatory response to hypoglycemia. In this regard glucagon stimulates glucose output by increasing liver glycogenolysis and gluconeogenesis (10). Next to its function in glucose metabolism, glucagon is also thought to play a role in lipolysis and amino acid metabolism which both have different effects on energy expenditure (EE). Nair et al showed already in 1987 that glucagon infusion can increase energy expenditure by increasing gluconeogenesis and protein oxidation (11). A stimulatory effect of glucagon on lipolysis has been suggested $(12,13)$, but inconsistent findings have been reported (12-15). Previous studies did not distinguish the effects of dietary carbohydrate and protein on glucagon and insulin secretion or their mutual influences $(8,9,16)$.

The purpose of the present study was to compare the thermogenic effects and hormonal responses to equicaloric protein hydrolysate and carbohydrate loads. We hypothesized that DIT would be higher after the protein hydrolysate than after the carbohydrate load and that this would be associated with a higher glucagon response. In addition, we investigated the interaction of the protein hydrolysate load with a carbohydrate pre- or afterload with respect to DIT and hormonal responses. The protein source used in these experiments was soy. However, in one of the trials, pea protein hydrolysate (PPH) was used to study possible differences between protein sources. Protein hydrolysates were used since there are indications that they are metabolized faster than intact protein (17). 


\section{Subjects and Methods}

\section{Subjects}

Eight healthy non-obese male subjects participated in this study (age $28.5 \pm 3.6$ year (19 - 48 year), weight $75.9 \pm 2.2 \mathrm{~kg}(66-82 \mathrm{~kg})$, height $1.81 \pm 0.02 \mathrm{~m}(1.75-1.95 \mathrm{~m})$, BMI $23.3 \pm 0.7 \mathrm{~kg} / \mathrm{m}^{2}\left(21.5-26.8 \mathrm{~kg} / \mathrm{m}^{2}\right)$; means $\pm \mathrm{SEM}$ (range) $)$. Subjects underwent a brief medical screening, including a medical history, and a fasting blood sample was collected. Subjects were excluded from the study if they were not weight stable over the past 2 months before enrollment, when fasting blood glucose levels were above 5.5 $\mathrm{mmol} / \mathrm{L}$, when $\mathrm{BMI}>27 \mathrm{~kg} / \mathrm{m}^{2}$ or when they were using medication. All subjects were informed about the nature and risks of the experimental procedures and their informed consent was obtained. The local Medical Ethical Committee approved this study.

\section{Experimental design}

The study consisted of 5 trials in which drinks containing soy protein hydrolysate (SPH), carbohydrate (CHO) and $\mathrm{SPH}$ with $\mathrm{CHO}$ as pre- or afterload were tested. Furthermore, pea protein hydrolysate (PPH) with a $\mathrm{CHO}$ after load was tested. All beverages were artificially sweetened and lemon flavored in order to make differences in taste as small as possible. Beverages were offered randomly (by means of Latin Square randomization) and in untransparent mugs in order to obtain a single-blind cross-over study. Two testing days were separated by at least 2 consecutive wash-out days. The time period to complete all trials varied for subjects between 14 and 33 days with a mean of 23 days. On testing days subjects came by car or by public transport to the lab after an overnight fast. They were asked to avoid heavy physical activity and to keep their eating pattern as constant as possible the day before the trials.

\section{Protocol}

After at least 10 hours fasting, subjects reported at approximately 8:00 am at the laboratory where the basal metabolic rate (BMR) was measured by indirect calorimetry using an open-circuit, ventilated-hood system with subjects lying in supine position. Before BMR measurements were started, subjects rested for at least 20 minutes in supine position. BMR was calculated from $\mathrm{O}_{2}$ consumption and $\mathrm{CO}_{2}$ production over 30 min using the formula of Weir (18). Respiratory quotient (RQ) was calculated as the ratio of the volume of carbon dioxide expired to the volume of oxygen consumed. After BMR measurements a Teflon catheter (Baxter BV, Utrecht, The Netherlands) was inserted into an antecubital vein and a resting blood sample was drawn $(t=0)$. Then subjects were offered a test drink which they had to consume as fast as possible and at least within 5 minutes. After finishing the test drink, DIT was determined by means of 
continuous indirect calorimetry over 2.5 hours. During this period subjects were not allowed to eat or drink. DIT measurements were interrupted once (after blood sampling at $\mathrm{t}=90$ ) on all experimental days to allow subjects to have a sanitary stop. Blood samples were drawn 15, 30, 60, 90, 120 and 150 minutes after finishing the test drink. In case of the trials with a $\mathrm{CHO}$ pre or afterload DIT measurements were interrupted shortly after 30 minutes for consumption of the second test drink.

\section{Beverages}

All beverages (approximately $250 \mathrm{ml}$ ) offered to the subjects consisted of $0.4 \mathrm{~g}$ protein hydrolysate $/ \mathrm{kg}$ body weight (BW) or of $0.4 \mathrm{~g}$ maltodextrin $/ \mathrm{kg}$ BW (AVB, Veendam, The Netherlands). This amount of proteins is comparable to the protein load ingested when eating a standard Dutch lunch (19) .The $\mathrm{pH}$ of all beverages was adjusted to $\mathrm{pH}$ 3.4 in a standard way with citric acid to optimize the taste profile of the flavoring compound (Lemon Flavor, Quest, Naarden, The Netherlands). Amino acid profiles of the different test drinks are given in Table 4.1.

Table 4.1 Amino acid composition of Soy and Pea protein hydrolysate

\begin{tabular}{lcc}
\hline Amino Acid & Soy & Pea \\
\hline Asx & 12.1 & 11.7 \\
Serine (Ser) & 5.2 & 5.7 \\
Glx & 19.7 & 19.9 \\
Histidine (His) & 2.5 & 2.4 \\
Glycine (Gly) & 4.3 & 4.0 \\
Threonine (Thr) & 3.9 & 4.0 \\
Arginine (Arg) & 7.4 & 9.8 \\
Alanine (Ala) & 4.4 & 5.4 \\
Tyrosin (Tyr) & 3.1 & 3.7 \\
Valine (Val) & 3.9 & 3.9 \\
Methionine (Met) & 1.2 & 0.9 \\
Isoleucine (Ile) & 3.7 & 3.4 \\
Phenylalanine (Phe) & 4.9 & 4.6 \\
Tryptophan (Trp) & 1.3 & 0.4 \\
Leucine (Leu) & 7.5 & 7.3 \\
Lysine (Lys) & 6.6 & 8.4 \\
Proline (Pro) & 6.4 & 4.0 \\
Cysteine (Cys) & 2.2 & 0.6 \\
\hline Values expressd & & \\
\hline
\end{tabular}

Values expressed as \% of total dry product

\section{Blood analyses}

Blood was collected in EDTA containing tubes for glucose, insulin, glucagon, free fatty acids (FFA), triglycerides (TG), lactate and urea analysis. EDTA blood to which aprotinin (5kIU/ml blood; Sigma-Aldrich Chemie BV) was added was used for 
glucagon analysis. After collection the blood sample was centrifuged at $1000 \mathrm{~g}$ at $4{ }^{\circ} \mathrm{C}$ for $10 \mathrm{~min}$. Aliquots of plasma were frozen immediately in liquid nitrogen and stored at - $45^{\circ} \mathrm{C}$. Glucose, FFA, lactate, urea and TG were analyzed with the COBAS FARA semi automatic analyzer (Roche Diagnostica, Basel, Switzerland). Insulin was quantitated by radioimmunoassay (Human Insulin Specific RIA kit, LINCO Research Inc., Missouri, USA) as was glucagon (Glucagon RIA kit, LINCO Research Inc., Missouri, USA).

\section{Statistics}

All data are expressed as means \pm SEM $(n=8)$. Statistical analysis was performed by using SPSS for Mac OS X software (SPSS Inc., Chicago, IL). Statistical analyses were done separately for the trials in which a single load was tested, for the trials in which SPH was combined with a CHO pre or afterload and for the trials in which SPH and $\mathrm{PPH}$ were followed by a $\mathrm{CHO}$ afterload. Plasma glucose, insulin, glucagon FFA, lactate, urea, TG responses were calculated as total area under the curve (AUC) (AUC above - AUC below baseline $(\mathrm{t}=0)$ ). Differences in AUC over $150 \mathrm{~min}$ were assessed by Wilcoxon Matched-Pairs Signed-Rank Tests. For each trial the time point that peak concentrations for a certain parameter were measured for most subjects, was chosen as time-to-peak. Delta values (concentration at time point $\mathrm{x}$ - baseline value) were calculated and differences in delta peak values were also tested by means of Wilcoxon Matched-Pairs Signed-Rank Tests. Multiple linear regression analysis was used to determine the contribution of insulin and glucagon to energy expenditure. A model was used in which EE was the dependent variable and insulin and/or glucagon responses were independent variables. Furthermore, the model was corrected for subject, trial and time point. At a p-level of 0.05 or smaller results were considered significantly different.

\section{Results}

\section{Single soy protein hydrolysate load versus single carbohydrate load}

Figure 4.1A shows that both conditions induced similar peak values for $\mathrm{EE}$ at $\mathrm{t}=30$ min $(p=0.32)$ but while EE decreased after $t=30 \mathrm{~min}$ in the CHO condition, it remained increased until $\mathrm{t}=120 \mathrm{~min}$ in the $\mathrm{SPH}$ condition. 

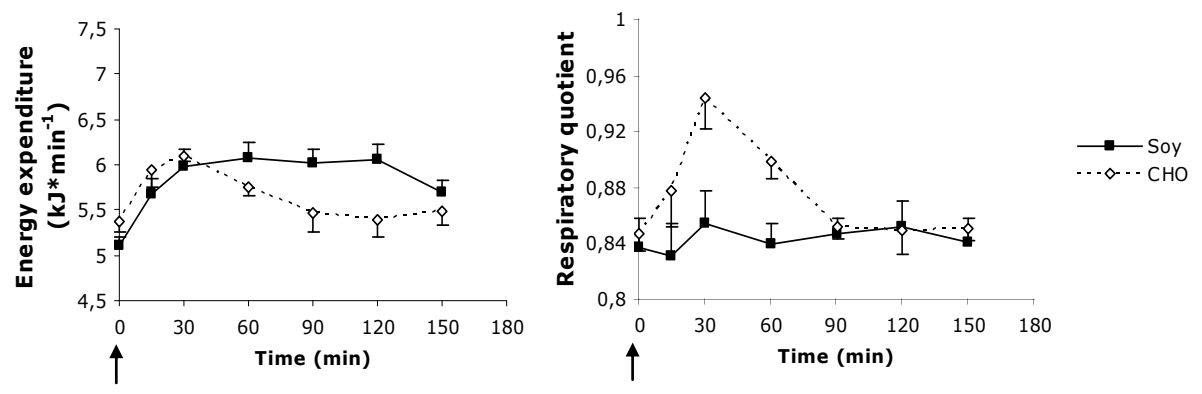

Figure 4.1

Change in energy expenditure (A) and respiratory quotient (B) over time after soy protein hydrolysate or carbohydrate consumption. $\uparrow$, moment of consumption (at $\mathrm{t}=0 \mathrm{~min}$ )

Delta values for EE ( $\triangle \mathrm{EE})$ were significantly higher after SPH than after $\mathrm{CHO}$ from $\mathrm{t}=$ 60 min onwards $(\mathrm{p} \leq 0.025)$. This difference resulted in a significantly higher AUC for EE after SPH consumption $(\mathrm{p}=0.012)$. No significant differences were found in AUC values for $R Q(p=0.33)$ (Table 4.2) but the delta values for RQ (at $t=30 \mathrm{~min})(\Delta \mathrm{RQ})$ were significantly higher in the CHO condition $(\mathrm{p}=0.035)$.

Figure 4.2A shows that a single $\mathrm{CHO}$ load induced a plasma glucose response with peak concentrations at $\mathrm{t}=30 \mathrm{~min}$, while a single equicaloric load of SPH did not affect plasma glucose. The AUC for glucose was significantly higher in the $\mathrm{CHO}$ compared to the protein condition $(\mathrm{p}=0.017)$ (Table 4.2).

Both conditions induced similar insulin responses (expressed as AUC, $p=0.89$ ) (Table 4.2). The $\mathrm{CHO}$ load did not induce a glucagon response in contrast to the SPH load with peak concentrations at $\mathrm{t}=30 \mathrm{~min}$. AUC values for glucagon differed significantly between $\mathrm{CHO}$ and SPH $(\mathrm{p}<0.01)$, as did delta values $(\Delta$ glucagon $)$ at $\mathrm{t}=30 \mathrm{~min}(\mathrm{p}=$ 0.012).

AUC values for free fatty acids (FFA) and triglycerides (TG) did not differ significantly $(p=0.48$ and $p=0.48$ respectively). AUC for lactate was significantly higher after CHO consumption $(\mathrm{p}=0.012)$, while AUC for urea was significantly higher after SPH consumption $(\mathrm{p}=0.012)($ Table 4.2). 

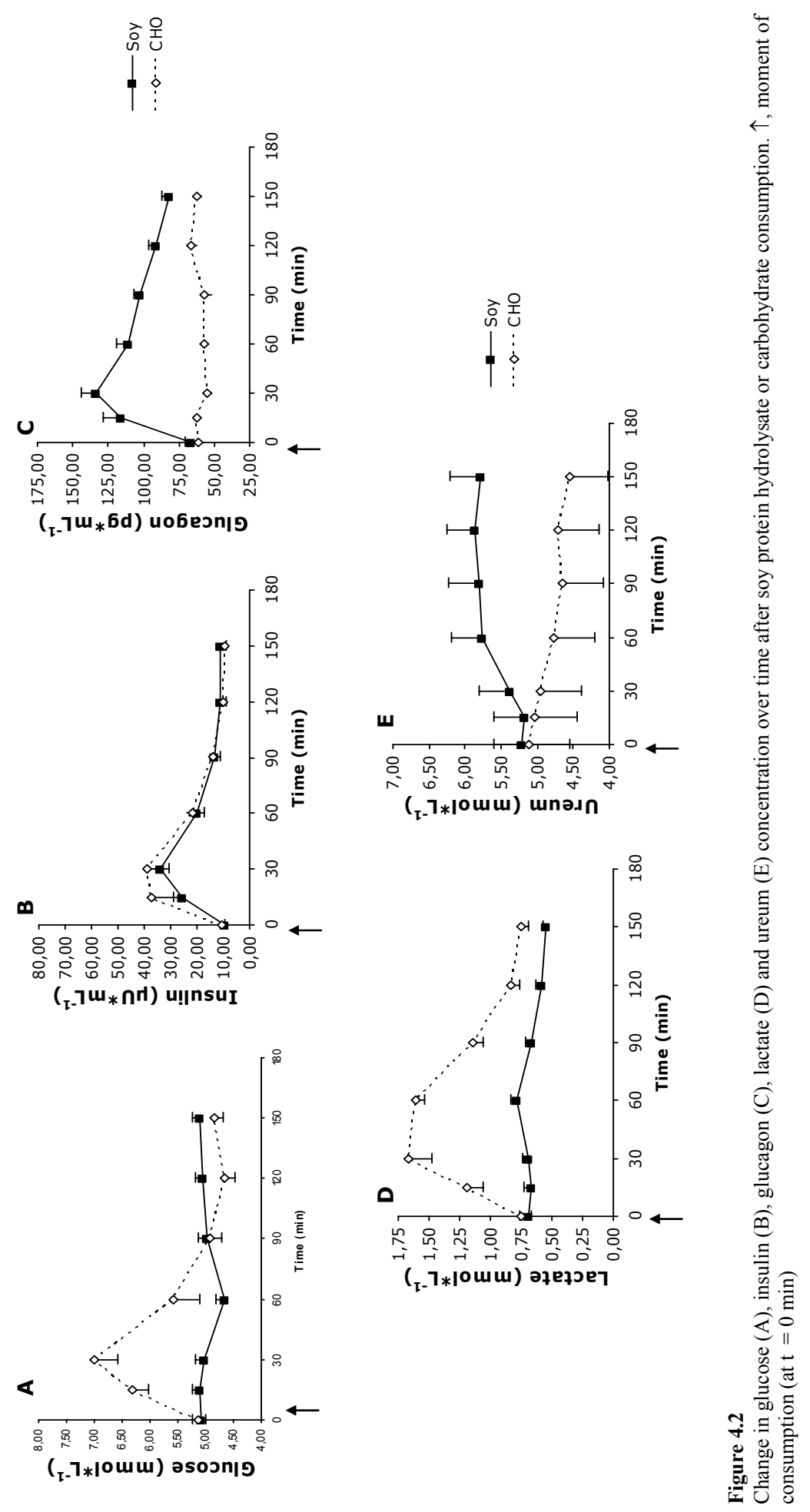
Table 4.2 Total AUC for parameters after ingestion of Soy protein hydrolysate and CHO

\begin{tabular}{cccc}
\hline & Soy & CHO & P-value \\
\hline Glucose & $-16.3 \pm 8.8$ & $48.8 \pm 15.9$ & 0.02 \\
Insulin & $1257.0 \pm 188.6$ & $1412.8 \pm 332.5$ & 0.89 \\
Glucagon & $5575.6 \pm 657.6$ & $-185.6 \pm 305.2$ & 0.00 \\
Free Fatty Acids & $-14116.0 \pm 6119.7$ & $-11356.0 \pm 3512.6$ & 0.48 \\
Triglycerides & $-15476.2 \pm 5446.7$ & $-10177.0 \pm 6202.0$ & 0.48 \\
Lactate & $-3.6 \pm 7.1$ & $67.9 \pm 8.7$ & 0.01 \\
Urea & $65.8 \pm 23.9$ & $-50.8 \pm 6.0$ & 0.01 \\
Energy Expenditure & $124.2 \pm 11.2$ & $38.8 \pm 7.6$ & 0.01 \\
Respiratory Quotient & $0.99 \pm 2.05$ & $3.48 \pm 1.77$ & 0.33 \\
\hline
\end{tabular}

Values are mean values \pm SEM

\section{Soy protein hydrolysate with a carbohydrate pre- or afterload}

Both conditions induced increases in EE and RQ, which, expressed as AUC, did not differ significantly ( $p=0.12$ and $p=0.33$ respectively) (Table 4.2). Peak values for $E E$ were not significantly different $(\mathrm{p}=0.07$ at $\mathrm{t}=60 \mathrm{~min} ; \mathrm{p}=0.779$ at $\mathrm{t}=90 \mathrm{~min})$ and no significant differences were found for $\Delta \mathrm{EE}$ at $\mathrm{t}=60 \mathrm{~min}$ or $\mathrm{t}=90 \mathrm{~min}$ between conditions ( $p=0.069$ and $p=0.779$ respectively). Peak values in RQ were found at $t=$ 30 min with the CHO preload while in case of the CHO afterload RQ values reached peak values at $\mathrm{t}=120 \mathrm{~min}$ (Figure 4.3B). At $\mathrm{t}=30 \mathrm{~min} \Delta \mathrm{RQ}$ was significantly higher with the CHO preload $(p=0.028)$.
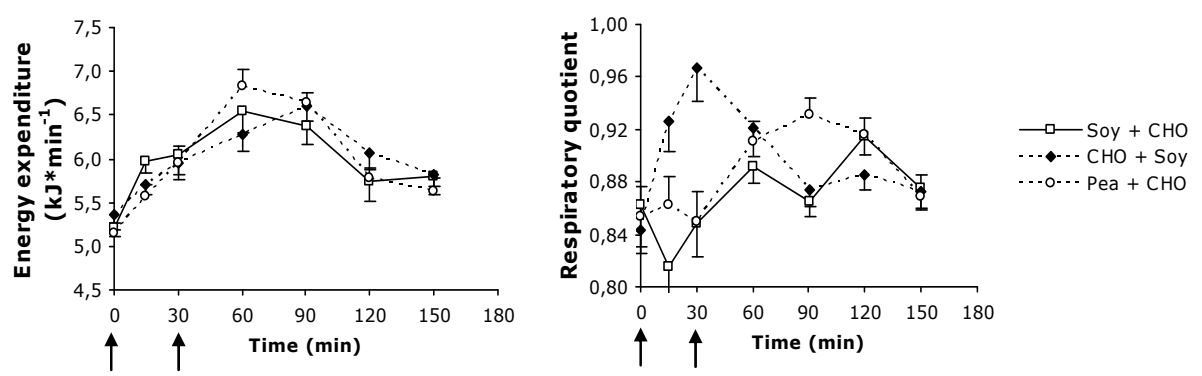

Figure 4.3

Change in energy expenditure (A) and respiratory quotient (B) over time after soy protein hydrolysate consumption with a carbohydrate pre- or afterload and after pea protein hydrolysate consumption with a carbohydrate afterload. $\uparrow$, moment of consumption (at $\mathrm{t}=0$ and at $\mathrm{t}=30 \mathrm{~min}$ )

Figure 4.4A shows that $\mathrm{SPH}$ preceded by a $\mathrm{CHO}$ load induced a plasma glucose response with peak concentrations at $\mathrm{t}=30 \mathrm{~min}$ while a SPH load followed by a $\mathrm{CHO}$ load did not affect plasma glucose concentrations. $\Delta$ glucose at $\mathrm{t}=30 \mathrm{~min}$ was significantly higher with the $\mathrm{CHO}$ preload $(\mathrm{p}=0.012)$. AUC values for both conditions differed significantly $(\mathrm{p}=0.012)$ (Table 4.3). 
Chapter 4
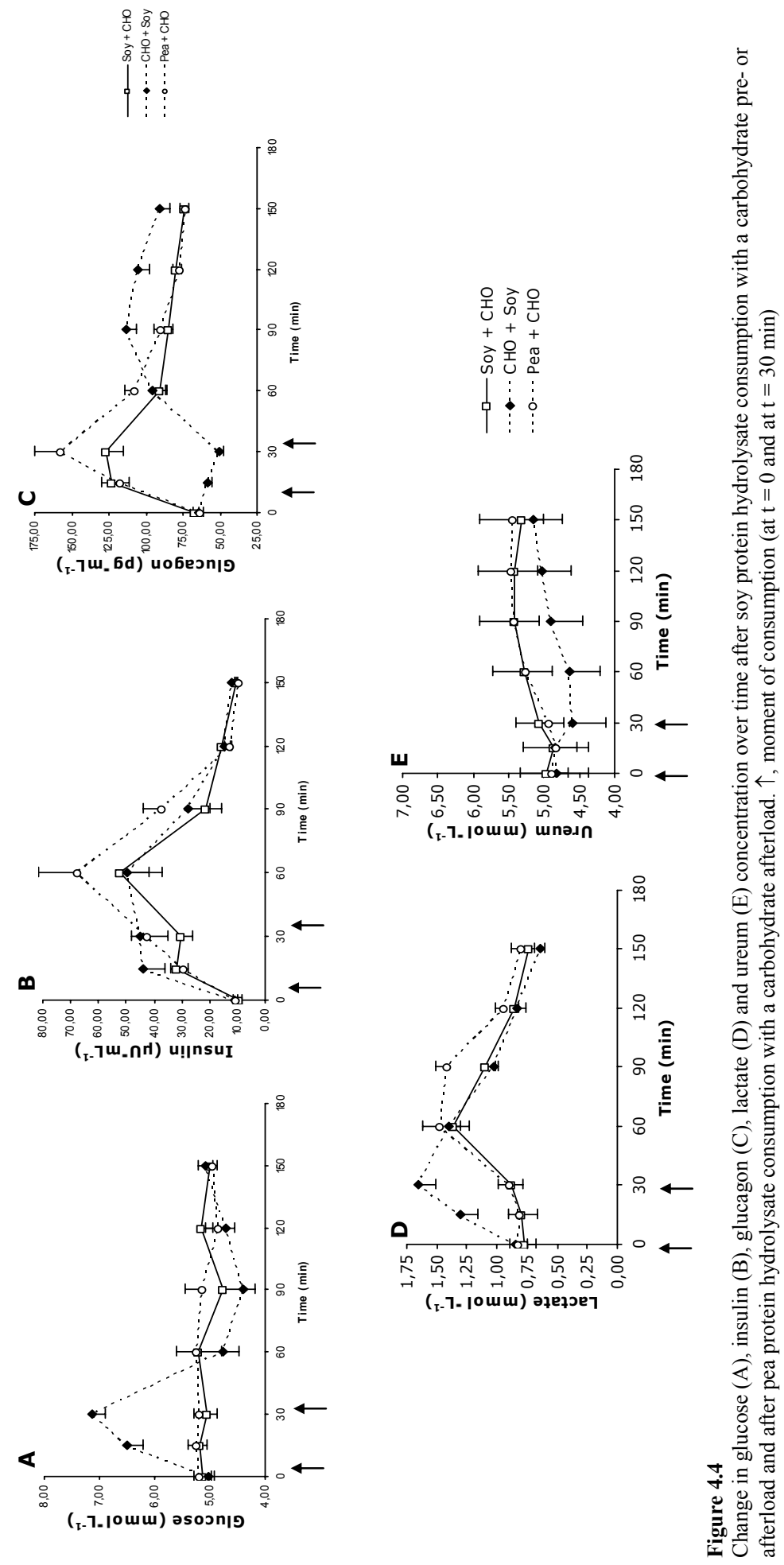
AUC's of insulin responses did not differ significantly $(p=0.263)$ and peak insulin concentrations were found at $\mathrm{t}=60 \mathrm{~min}$ in both conditions and also were not significantly different $(\mathrm{p}=0.36)$. Glucagon concentrations did not change significantly after $\mathrm{CHO}$ preload consumption and increased when SPH was consumed 30 min later, reaching peak values at $\mathrm{t}=90 \mathrm{~min}$. When $\mathrm{SPH}$ was consumed first, a glucagon response was induced immediately, reaching peak values at $\mathrm{t}=30 \mathrm{~min}$. AUC values for glucagon were not significantly different between the two conditions $(p=0.67)$ (Table 4.3), but the time course of the glucagon responses was clearly different (Figure $4.4 \mathrm{C}$ ).

Table 4.3 Total AUC for parameters after ingestion of Soy protein hydrolysate with CHO as pre or after load

\begin{tabular}{cccc}
\hline & Soy + CHO & CHO + Soy & P-value \\
\hline Glucose & $-10.9 \pm 22.4$ & $34.6 \pm 12.6$ & 0.01 \\
Insulin & $2654.0 \pm 577.7$ & $3062.4 \pm 691.7$ & 0.26 \\
Glucagon & $3955.7 \pm 605.2$ & $3625.7 \pm 490.6$ & 0.67 \\
Free Fatty Acids & $-16599 \pm 2794$ & $-13324 \pm 2915$ & 0.48 \\
Triglycerides & $-4515.7 \pm 3928.1$ & $-7879.0 \pm 6336.3$ & 0.78 \\
Lactate & $31.5 \pm 6.3$ & $44.3 \pm 9.4$ & 0.78 \\
Urea & $40.7 \pm 11.3$ & $-5.6 \pm 8.7$ & 0.02 \\
Energy Expenditure & $133.1 \pm 13.6$ & $112.6 \pm 16.7$ & 0.12 \\
Respiratory Quotient & $1.75 \pm 4.31$ & $7.58 \pm 1.81$ & 0.33 \\
\hline
\end{tabular}

Values are mean values \pm SEM

AUC values for FFA, TG and lactate did not differ significantly between conditions ( $\mathrm{p}$ $=0.48, \mathrm{p}=0.78$ and $\mathrm{p}=0.78$ respectively). AUC for urea was significantly lower when SPH consumption was preceded by the CHO load compared to the situation in which $\mathrm{CHO}$ was given as an afterload $(\mathrm{p}=0.017)$ (Table 4.3).

\section{Soy versus pea protein hydrolysate with a CHO afterload}

EE and RQ responses expressed as AUC values, did not differ between soy and pea $(\mathrm{p}=$ 0.21 and $\mathrm{p}=0.67$ respectively) (Table 4.4 ).

Similar to SPH, PPH prevented the $\mathrm{CHO}$-induced increase in plasma glucose concentration $(\mathrm{p}=0.99)$ (Table 4.4).

PPH induced significantly higher insulin and glucagon responses than SPH expressed as AUC values $(\mathrm{p}=0.017$ and $\mathrm{p}=0.012$ respectively). The $\Delta$ glucagon value (at $\mathrm{t}=30$ min) was significantly higher after PPH than after SPH $(p=0.05)$.

The AUC's for FFA, TG, lactate and urea did not differ significantly between conditions (Table 4.4). 


\section{Association between insulin and/or glucagon and energy expenditure}

Regression analyses were done to study how insulin and/or glucagon influence EE. Multiple linear regression analyses over all trials with EE as dependent variable showed that the model corrected for subject, trial and time point but without insulin or glucagon concentrations, explained $0.7 \%$ of the variability in EE. When glucagon was included in this model it explained $13.4 \%$ of the variability (partial correlation of $0.361, p<0.001$ ) and inclusion of insulin in the model explained $27.9 \%$ of the variability (partial correlation of $0.526, \mathrm{p}<0.000$ ). When both glucagon and insulin were included in the model, it explained $33.2 \%$ of the variability in EE.

Table 4.4 Total AUC for parameters after ingestion of Soy and Pea protein hydrolysate with a CHO after load

\begin{tabular}{cccc}
\hline & Soy + CHO & Pea + CHO & P-value \\
\hline Glucose & $-10.9 \pm 22.4$ & $-10.7 \pm 20.1$ & 0.99 \\
Insulin & $2654.0 \pm 577.7$ & $3534.6 \pm 588.5$ & 0.02 \\
Glucagon & $3955.7 \pm 605.2$ & $5589.2 \pm 400.7$ & 0.01 \\
Free Fatty Acids & $-16599 \pm 2794$ & $-14501 \pm 4807$ & 0.73 \\
Triglycerides & $-4515.7 \pm 3928.1$ & $3199.4 \pm 4807.4$ & 0.26 \\
Lactate & $31.5 \pm 6.3$ & $42.2 \pm 6.2$ & 0.29 \\
Urea & $40.7 \pm 11.3$ & $54.7 \pm 7.6$ & 0.11 \\
Energy Expenditure & $133.1 \pm 13.6$ & $149.9 \pm 15.8$ & 0.21 \\
Respiratory Quotient & $1.75 \pm 4.31$ & $6.81 \pm 2.19$ & 0.67 \\
\hline
\end{tabular}

Values are mean values \pm SEM

\section{Discussion}

In the present study we showed that SPH induced a higher thermogenic response than an equicaloric $\mathrm{CHO}$ drink and was associated with a higher glucagon response and a similar insulin response. Furthermore, we showed that the protein-induced DIT is not influenced by a $\mathrm{CHO}$ pre- or afterload. Interestingly, this study demonstrated that when a $\mathrm{CHO}$ load was preceded by protein hydrolysate consumption, the rise in plasma glucose expected after $\mathrm{CHO}$ consumption did not occur. Finally, our results demonstrate that PPH induced a higher glucagon response than SPH.

\section{Single soy protein hydrolysate load versus single carbohydrate load}

SPH caused a significantly higher DIT than the equicaloric maltodextrin load (Figure 4.1). A higher EE after a single protein load or a mixed high-protein meal compared to an equicaloric single carbohydrate, fat or mixed low-protein meal has been demonstrated before $(6,20-23)$. In accordance with Crovetti et al (1998) (24) the difference in DIT between a protein load and a CHO load was not due to the differences in the initial rise in EE but to a prolonged increase in EE after SPH ingestion. High- 
protein meals are associated with increased post-absorptive protein synthesis (25), which has a high metabolic cost (26). In addition, a thermogenic effect of glucagon has been demonstrated previously by means of glucagon infusion experiments (11). It was proposed that the increased EE during glucagon infusion was mainly related to stimulation of gluconeogenesis and ureagenesis by glucagon (11). After SPH consumption we indeed found significantly higher glucagon and urea responses (as AUC) compared to $\mathrm{CHO}$ consumption. We found that the insulin response was similar after SPH and CHO ingestion (Figure 4.2). This is in agreement with Nair et al (1983) who showed that single equicaloric protein and carbohydrate loads induced similar insulin responses (21). In contrast, the group of Nuttall and Gannon who compared the effect of ingestion of $50 \mathrm{~g}$ glucose in a drink or $50 \mathrm{~g}$ protein in the form of cooked lean hamburger $(6.5 \%$ fat $)$ on insulin concentration found that the insulin stimulating effect of the hamburger meal was much less potent than that of the glucose drink (16, 27-28). The difference with our findings may be due to a lower gastric emptying rate of lean beef compared to a protein hydrolysate drink. In agreement with these studies $(16,28)$ we found no significant effect of protein ingestion alone on plasma glucose levels in healthy lean subjects. Stimulation of gluconeogenesis from amino acids by glucagon is likely to have contributed to the normal glucose concentrations despite the increase in insulin after SPH consumption. In this way the body is protected from hypoglycemia after protein ingestion. Since we did not find differences in plasma FFA and TG responses and no increase in fatty acid oxidation there is no evidence that the prolonged DIT after SPH consumption is linked to increased glucagon-induced adipose tissue lipolysis.

\section{Soy protein hydrolysate with a carbohydrate pre- or afterload}

Thermogenesis induced by SPH combined with a CHO load was not influenced by the order of consumption. In both cases consumption of a second bolus induced an extra increase in EE and insulin (Figures 4.3 and 4.4) and total responses were not different in both conditions (Table 4.3). Although AUC values for glucagon were similar in both situations (Table 4.3), the time course of the response was clearly different (Figure 4.4). Figure 4.3 shows that the rise in RQ after a $\mathrm{CHO}$ preload decreases after the SPH afterload similarly as after a singly $\mathrm{CHO}$ load, while RQ values remain rather low in the $\mathrm{CHO}$ afterload condition. Although no significant difference is found in lactate response (reflecting glycolysis), plasma urea response is significantly different between both conditions (reflecting protein turnover) (Table 4.3). Although in the CHO preload condition urea concentrations decreased during the first hour, they increased afterwards (Figure 4.4) indicating a switch in substrate oxidation. 
Figure 4.4 shows that a $\mathrm{CHO}$ pre- or afterload has a similar influence on the protein induced insulin response. In both cases peak values for insulin are reached at $t=60$. In addition we find that the additional effect of proteins on the $\mathrm{CHO}$-induced insulin response as described previously $(27,29)$ is not influenced by the timing of consumption of the protein or carbohydrate load. This can be deducted from the observation that protein hydrolysate consumption with both $\mathrm{CHO}$ as pre- or afterload induces insulin responses similar to each other, which are double the insulin response after a single protein or $\mathrm{CHO}$ load.

Furthermore, we found that when SPH consumption was followed by an equicaloric $\mathrm{CHO}$ load this $\mathrm{CHO}$ consumption did not result in a rise in plasma glucose concentrations. This suggests that in this condition glucose that reaches circulation disappears rapidly into tissues to be metabolized. This can be explained by the already elevated plasma insulin levels induced by the protein load prior to $\mathrm{CHO}$ consumption. The rise in lactate when the $\mathrm{CHO}$ is ingested after the protein suggests that glucose is partly metabolized into lactate in an extra-hepatic way, which is in accordance with the glucose paradox (30). The finding that protein ingestion prior to $\mathrm{CHO}$ prevents the $\mathrm{CHO}$-induced increase in blood glucose is of interest in view of the discussion about glycemic index and its effect on health (31), since this condition may allow ingestion of high glycemic index carbohydrates without the associated high blood glucose response. To find out how protein/peptide preloads influence plasma glucose levels over 24 hours or over longer periods of time, long-term studies with high-protein diets should be performed.

Concerning glucagon responses no differences were found in the overall response induced by SPH with a CHO pre- or afterload. Figure 4.4, however, shows that the pattern of the glucagon responses is clearly different. Although postprandial insulindriven suppression of glucagon secretion has been suggested (32) we did not find an effect of the $\mathrm{CHO}$ preload-induced insulin response on the glucagon-inducing effect of SPH. This observation supports the hypothesis that the amino acid-induced glucagon secretion is not or only partly inhibited by increased insulin levels (33).

\section{Soy versus pea protein hydrolysate with carbohydrate afterload}

In this additional trial we wanted to study the effect of a different vegetable protein source (pea protein) of which a previous study showed that it induced the highest insulin and glucagon levels compared to the other protein hydrolysates from vegetable origin tested (soy, rice and gluten) (Chapter 2).

No significant differences in DIT or RQ were found between both conditions but PPH induced a significantly higher insulin and glucagon response compared to $\mathrm{SPH}$. Although PPH induced a higher glucagon response we did not find significantly higher 
DIT compared to SPH. This may be due to the absolute difference in glucagon concentration at the different time points was not large enough for inducing higher EE. Another explanation could be that the effect of glucagon on DIT was already maximal at the glucagon concentration attained after SPH consumption and an additional increase in glucagon concentration could not increase DIT further.

The explanation for the higher insulin and glucagon response after $\mathrm{PPH}$ than SPH consumption is not directly evident from our study. Calbet \& MacLean (2002) reported previously that the rate of gastric emptying of pea and whey hydrolysate was comparable (9). Although we cannot exclude the possibility that SPH has a different rate of gastric emptying than whey protein hydrolysate, this does not seem very likely. The difference in insulin and glucagon response between both protein sources can, therefore, not be explained by differences in gastric emptying. In a previous study we found that the branched-chain amino acids (Leu, Ile and Val) were the best predictors of the insulin and glucagon response (Chapter 2). Since soy and pea protein contain similar amounts of branched-chain amino acids, differences in branched-chain amino acid content of SPH and PPH cannot explain the difference in glucagon and insulin response. Specific amino acids, such as arginine, glycine, alanine, lysine, phenylalanine, methionine and tyrosine have been reported to be more insulin- and/or glucagonstimulating than others $(9,34-37)$. Since arginine and lysine were more abundant in $\mathrm{PPH}$ than in SPH, this difference might be responsible for the differences found in insulin and glucagon response between SPH and PPH.

\section{Association between insulin and/or glucagon and energy expenditure}

To find out to what extent insulin and glucagon separately and together contribute to changes in EE independent of the trials multiple linear regression analyses corrected for subject, trial and time point were performed with EE as dependent variable and glucagon and/or insulin concentrations as independent. These analyses showed that insulin contributes most to changes in EE (27.9\%) but when glucagon is also included in the model significantly more variation in EE is explained $(33,2 \%, \mathrm{p}<0.001)$. Whether insulin and glucagon have a direct effect on EE remains to be investigated.

In summary, a single protein hydrolysate drink induced a more prolonged increase in EE, similar insulin and higher glucagon response than an equicaloric carbohydrate drink. Plasma insulin and glucagon were both predictors of EE. The rise in plasma glucose after carbohydrate consumption did not occur when ingestion of the carbohydrate drink was preceded by ingestion of a protein hydrolysate drink. Finally it is likely that there will be no large differences in response after ingestion of intact 
Chapter 4

protein drinks compared to hydrolysates (9), but the effect of ingesting high-protein and/or high-carbohydrate foods remains to be investigated.

\section{Acknowledgements}

The study described in this article were financially supported by Kerry Bio-Science, Almere, The Netherlands. The authors would like to thank Dr. W. Calame and Dr. A.D. Siemensma from Kerry Bioscience for their contributions and fruitful discussions. 


\section{References}

1. Eisenstein, J., Roberts, S. B., Dallal, G. \& Saltzman, E. (2002) High-protein weight-loss diets: are they safe and do they work? A review of the experimental and epidemiologic data. Nutr Rev 60: 189-200.

2. Johnston, C. S., Tjonn, S. L. \& Swan, P. D. (2004) High-protein, low-fat diets are effective for weight loss and favorably alter biomarkers in healthy adults. J Nutr 134: 586-591.

3. Westerterp-Plantenga, M. S., Lejeune, M. P., Nijs, I., van Ooijen, M. \& Kovacs, E. M. (2004) High protein intake sustains weight maintenance after body weight loss in humans. Int J Obes Relat Metab Disord 28: 57-64.

4. Lejeune, M. P., Westerterp, K. R., Adam, T. C., Luscombe-Marsh, N. D. \& Westerterp-Plantenga, M. S. (2006) Ghrelin and glucagon-like peptide 1 concentrations, 24-h satiety, and energy and substrate metabolism during a high-protein diet and measured in a respiration chamber. Am J Clin Nutr 83: 89-94.

5. Raben, A., Agerholm-Larsen, L., Flint, A., Holst, J. J. \& Astrup, A. (2003) Meals with similar energy densities but rich in protein, fat, carbohydrate, or alcohol have different effects on energy expenditure and substrate metabolism but not on appetite and energy intake. Am J Clin Nutr 77: 91-100.

6. Johnston, C. S., Day, C. S. \& Swan, P. D. (2002) Postprandial thermogenesis is increased $100 \%$ on a high-protein, low-fat diet versus a high-carbohydrate, low-fat diet in healthy, young women. J Am Coll Nutr 21: 55-61.

7. Newsholme, P., Brennan, L., Rubi, B. \& Maechler, P. (2005) New insights into amino acid metabolism, beta-cell function and diabetes. Clin Sci (Lond) 108: 185-194.

8. Kabadi, U. M. (1991) Dose-kinetics of pancreatic alpha- and beta-cell responses to a protein meal in normal subjects. Metabolism 40: 236-240.

9. Calbet, J. A. \& MacLean, D. A. (2002) Plasma glucagon and insulin responses depend on the rate of appearance of amino acids after ingestion of different protein solutions in humans. J Nutr 132: 21742182.

10. Jiang, G. \& Zhang, B. B. (2003) Glucagon and regulation of glucose metabolism. Am J Physiol Endocrinol Metab 284: E671-678.

11. Nair, K. S. (1987) Hyperglucagonemia increases resting metabolic rate in man during insulin deficiency. J Clin Endocrinol Metab 64: 896-901.

12. Perea, A., Clemente, F., Martinell, J., Villanueva-Penacarrillo, M. L. \& Valverde, I. (1995) Physiological effect of glucagon in human isolated adipocytes. Horm Metab Res 27: 372-375.

13. Carlson, M. G., Snead, W. L. \& Campbell, P. J. (1993) Regulation of free fatty acid metabolism by glucagon. J Clin Endocrinol Metab 77: 11-15.

14. Bertin, E., Arner, P., Bolinder, J. \& Hagstrom-Toft, E. (2001) Action of glucagon and glucagon-like peptide-1-(7-36) amide on lipolysis in human subcutaneous adipose tissue and skeletal muscle in vivo. J Clin Endocrinol Metab 86: 1229-1234.

15. Gravholt, C. H., Moller, N., Jensen, M. D., Christiansen, J. S. \& Schmitz, O. (2001) Physiological levels of glucagon do not influence lipolysis in abdominal adipose tissue as assessed by microdialysis. J Clin Endocrinol Metab 86: 2085-2089.

16. Westphal, S. A., Gannon, M. C. \& Nuttall, F. Q. (1990) Metabolic response to glucose ingested with various amounts of protein. Am J Clin Nutr 52: 267-272.

17. Calbet, J. A. \& Holst, J. J. (2004) Gastric emptying, gastric secretion and enterogastrone response after administration of milk proteins or their peptide hydrolysates in humans. Eur J Nutr 43: 127-139.

18. Weir, J. B. (1949) New methods for calculating metabolic rate with special reference to protein metabolism. 1949. J Physiol 109: 1-9. 
19. Zo eet Nederland, 1998. Resultaten van de Voedselconsumptiepeiling 1997-1998. Den Haag. Voedingscentrum 1998. Drukkerij ten Brink.

20. Robinson, S. M., Jaccard, C., Persaud, C., Jackson, A. A., Jequier, E. \& Schutz, Y. (1990) Protein turnover and thermogenesis in response to high-protein and high-carbohydrate feeding in men. Am $\mathrm{J}$ Clin Nutr 52: 72-80.

21. Nair, K. S., Halliday, D. \& Garrow, J. S. (1983) Thermic response to isoenergetic protein, carbohydrate or fat meals in lean and obese subjects. Clin Sci (Lond) 65: 307-312.

22. Karst, H., Steiniger, J., Noack, R. \& Steglich, H. D. (1984) Diet-induced thermogenesis in man: thermic effects of single proteins, carbohydrates and fats depending on their energy amount. Ann Nutr Metab 28: 245-252.

23. Swaminathan, R., King, R. F., Holmfield, J., Siwek, R. A., Baker, M. \& Wales, J. K. (1985) Thermic effect of feeding carbohydrate, fat, protein and mixed meal in lean and obese subjects. Am J Clin Nutr 42: 177-181.

24. Crovetti, R., Porrini, M., Santangelo, A. \& Testolin, G. (1998) The influence of thermic effect of food on satiety. Eur J Clin Nutr 52: 482-488.

25. Pannemans, D. L., Halliday, D., Westerterp, K. R. \& Kester, A. D. (1995) Effect of variable protein intake on whole-body protein turnover in young men and women. Am J Clin Nutr 61: 69-74.

26. Rolfe, D. F. \& Brown, G. C. (1997) Cellular energy utilization and molecular origin of standard metabolic rate in mammals. Physiol Rev 77: 731-758.

27. Nuttall, F. Q., Mooradian, A. D., Gannon, M. C., Billington, C. \& Krezowski, P. (1984) Effect of protein ingestion on the glucose and insulin response to a standardized oral glucose load. Diabetes Care 7: 465-470.

28. Krezowski, P. A., Nuttall, F. Q., Gannon, M. C. \& Bartosh, N. H. (1986) The effect of protein ingestion on the metabolic response to oral glucose in normal individuals. Am J Clin Nutr 44: 847-856.

29. Rabinowitz, D., Merimee, T. J., Maffezzoli, R. \& Burgess, J. A. (1966) Patterns of hormonal release after glucose, protein, and glucose plus protein. Lancet 2: 454-456.

30. Katz, J. \& McGarry, J. D. (1984) The glucose paradox. Is glucose a substrate for liver metabolism? J Clin Invest 74: 1901-1909.

31. Ludwig, D. S., Majzoub, J. A., Al-Zahrani, A., Dallal, G. E., Blanco, I. \& Roberts, S. B. (1999) High glycemic index foods, overeating, and obesity. Pediatrics 103: E26.

32. Meier, J. J., Kjems, L. L., Veldhuis, J. D., Lefebvre, P. \& Butler, P. C. (2006) Postprandial suppression of glucagon secretion depends on intact pulsatile insulin secretion: further evidence for the intraislet insulin hypothesis. Diabetes 55: 1051-1056.

33. Pipeleers, D. G., Schuit, F. C., Van Schravendijk, C. F. \& Van de Winkel, M. (1985) Interplay of nutrients and hormones in the regulation of glucagon release. Endocrinology 117: 817-823.

34. Sanchez, A. \& Hubbard, R. W. (1991) Plasma amino acids and the insulin/glucagon ratio as an explanation for the dietary protein modulation of atherosclerosis. Med Hypotheses 36: 27-32.

35. Sugano, M., Ishiwaki, N. \& Nakashima, K. (1984) Dietary protein-dependent modification of serum cholesterol level in rats. Significance of the arginine/lysine ratio. Ann Nutr Metab 28: 192-199.

36. Hubbard, R., Kosch, C. L., Sanchez, A., Sabate, J., Berk, L. \& Shavlik, G. (1989) Effect of dietary protein on serum insulin and glucagon levels in hyper- and normocholesterolemic men. Atherosclerosis 76: $55-61$.

37. Palmer, J. P., Walter, R. M. \& Ensinck, J. W. (1975) Arginine-stimulated acute phase of insulin and glucagon secretion. I. in normal man. Diabetes 24: 735-740. 


\section{Chapter 5}

\section{A protein- versus carbohydrate-enriched ad libitum low-fat diet improves weight control and cardiovascular risk factors in overweight and obese subjects after weight loss}

Mandy Claessens, Marleen A van Baak, Sandy Monsheimer, Wim HM Saris

Nutrition and Toxicology Research Institute Maastricht (NUTRIM), Department of Human Biology, Maastricht University, Maastricht, The Netherlands

This work was supported by Kerry Bio-Science, Almere, The Netherlands

Submitted 


\begin{abstract}
Background: Dietary proteins have a beneficial effect on weight management and may influence postprandial substrate utilization by inducing insulin and glucagon secretion.
\end{abstract}

Objective: The aim was to compare the effects of a maltodextrin-enriched highcarbohydrate (HC) and high-protein (HP) enriched with either casein (HPC) or whey (HPW) ad libitum diet on body weight, energy intake, blood pressure and parameters of glucose and lipid metabolism in healthy obese subjects.

Design: Forty-eight subjects completed the study that consisted of an energy restriction period followed by a weight maintenance period of 12 weeks. During weight maintenance subjects were guided towards a HC or HP diet with maltodextrin or protein (casein or whey) supplements (50 g/day) respectively.

Results: Subjects in the HP diet group showed significantly better weight maintenance after weight loss than subjects in the HC group $(\mathrm{p}=0.035)$. Triglyceride (TG) and glucagon concentrations decreased and glucose concentrations increased more in the HP diet group. LDL:HDL ratio decreased in the HPC but not HPW when compared to the HC group.

Conclusions: A high-protein diet after weight loss improved maintenance of weight loss by reducing fat mass but not fat free mass. The LDL:HDL ratio decreased in a protein-source specific manner. 


\section{Introduction}

In overweight and obese people weight loss is known to improve glycemic control, blood lipid profiles and other conditions that otherwise may contribute to the development of diabetes and cardiovascular disease $(1,2)$. High-protein diets are considered to be more effective regarding weight loss and weight maintenance than diets with higher carbohydrate-to-protein or fat-to-protein ratios because of their high satiating and thermogenic effect (3-9). In addition to their beneficial effect on weight management, dietary proteins also influence glycemic control by increasing the acute glucose-induced insulin response, both in healthy and in insulin resistant subjects (1012), and by inducing glucagon secretion (12-14). It has been reported that high-protein diets reduce hyperglycemia (15) and improve insulin sensitivity (16-18) in insulin resistant subjects, although this finding is not consistent $(19,20)$. Insulin and glucagon are also thought to play a role in the control of cholesterol. There is evidence that insulin is positively associated with total and low density lipoprotein (LDL) cholesterol and triglycerides and inversely with high density lipoprotein (HDL) cholesterol (21-23). Glucagon, on the contrary, is thought to reduce cholesterol synthesis and circulating LDL cholesterol levels (21-23). It is suggested that insulin acts via up-regulation of the transcription factor sterol regulatory element binding protein (SREBP) 1 that increases the expression of lipogenic genes (24). Glucagon counteracts the insulin activity by repressing SREBP expression through a cAMP-dependent mechanism (24). Therefore, the insulin:glucagon ratio is hypothesized to be positively associated with the development of cardiovascular disease via its effect on cholesterol composition in the circulation (21-23).

Whether high-protein diets affect fasting insulin and glucagon levels and whether protein source is of importance is poorly studied. Proteins can, in similarity to carbohydrates, be divided in so-called fast and slow proteins (25). Fast proteins, such as whey protein, are soluble, while slow proteins, such as casein, clot in the stomach resulting in a delay in gastric emptying $(26,27)$ and lower peak but more sustained plasma amino acid levels compared to fast proteins $(25,27,28)$, which may be associated with differences in hormonal and thermogenic responses (29). Hall et al (2003) found that higher postprandial circulating levels of amino acids are associated with increased satiety and suggested that fast proteins are, therefore, more satiating than slow proteins (28). Slow proteins, on the other hand, could induce prolonged stimulation of gastric feedback signals contributing to meal termination because of the prolonged enhanced gastric volume compared to fast proteins (30). The role of slow or 
fast proteins in weight management and the risk of cardiovascular disease and diabetes remain to be investigated.

The aim of the present study was to compare the weight management effects of an ad libitum diet high in carbohydrate (HC) with ad libitum diets high in protein (HP), either casein-based (a slow protein) (HPC) or whey-based (a fast protein) (HPW), on body weight regain in healthy obese subjects after a substantial diet-induced weight loss. Additionally, the effects on body composition, blood pressure, energy intake and fasting plasma insulin, glucagon, glucose and lipid profiles were studied.

\section{Subjects and Methods}

\section{Subjects}

Sixty overweight and obese subjects $\left(\mathrm{BMI} \geq 27 \mathrm{~kg} / \mathrm{m}^{2}\right)$ of both genders, aged $30-60 \mathrm{y}$, were recruited by public advertisement. Subjects underwent a brief medical screening examination, including a medical history, a routine physical examination and blood tests (fasting glucose, triglycerides (TG), cholesterol). Subjects had to be weight stable over the past 2 months before enrollment. Subjects were excluded when, at screening, fasting glucose $(>6 \mathrm{mmol} / \mathrm{l}), \mathrm{TG}(>2.3 \mathrm{mmol} / \mathrm{l})$ or total cholesterol levels $(>6.5 \mathrm{mmol} / \mathrm{l})$ were increased or when diastolic blood pressure exceeded $100 \mathrm{mmHg}$. Furthermore, subjects were excluded during the study when they were unable to lose at least $5 \%$ of their initial body weight during the weight loss period or when they changed their life-style dramatically during the study period.

Of the 60 subjects included, 48 (31 women and 18 men) completed the study, 6 subjects dropped out during the weight loss period (4 subjects during the energy restriction period and 2 subjects had lost less than $5 \%$ of their initial body weight at the end of the weight loss period and were excluded), 6 during the intervention ( 2 were not able to comply and 4 due to personal reasons). One subject was excluded from analyses due to dramatic changes in life-style during the intervention period.

The study was approved by the Medical Ethics Committee of the Academic Hospital in Maastricht and all subjects gave written informed consent before entering the study.

\section{Experimental design}

Subjects were matched for BMI, age and gender and randomly assigned to the highcarbohydrate (HC), high-protein casein (HPC), or high-protein whey (HPW) group. The study consisted of a 5-week weight loss period using a Very Low Calorie Diet (VLCD) and a 12-week weight maintenance period with one week in-between to change to normal food. During the 5-week VLCD period subjects consumed $500 \mathrm{kcal}$ of a 
complete meal replacer a day (3 sachets Modifast (Nutrition et Santé, Belgium) dissolved in water). Subjects were allowed to eat an unrestricted amount of certain types of vegetables as indicated by a dietician. During week 6 Modifast was gradually replaced by normal ad libitum meals to which supplements were gradually incorporated according to the dietary group the subjects were randomized to before the start of the study. During the weight maintenance period subjects received dietary counseling from a dietician in order to achieve a fat intake of approximately $30 \mathrm{En} \%$ in all groups and a carbohydrate intake of at least $55 \mathrm{En} \%$ in the $\mathrm{HC}$ group and a protein intake of at least $25 \mathrm{En} \%$ in both high-protein groups. Although subjects were guided in the macronutrient composition of their diet, they were allowed to eat ad libitum. In addition to this diet, the HC group consumed maltodextrin supplements (AVB, Veendam, The Netherlands) twice a day (50 g/day). The HPC and HPW groups consumed intact casein (Kerry Ingredients, Tralee, Ireland) or whey supplements (Carberry, Cork, Ireland) twice a day (50 g/day), respectively. Maltodextrin supplements were orange-flavored, while both protein supplements were strawberry-flavored. Subjects were asked to consume one supplement during the morning and the other in the afternoon $( \pm 1.5$ hour before dinner).

\section{Questionnaires}

Before the start of the VLCD period and at the end of the weight maintenance period, subjects filled out a 3-day food record ( 2 weekdays and 1 weekend day), which was used to analyze energy and macronutrient intake. A dietician analyzed food records with a computer program according to the Dutch food table (Komeet 4.0).

To check whether subjects kept their physical activity constant during the intervention period, they had to fill in the Baecke questionnaire for physical activity (31) before and after the weight maintenance period.

\section{Measurements}

Subjects came to the lab in a fasted state at the beginning of the energy restriction period (week 0), after changing back completely to normal food (week 6) and 2, 4, 8 and 12 weeks thereafter (from now on designated as week 8, 10, 14 and 18 of the study). Body weight (BW) and blood pressure was measured at all visits to the lab. At week 0,6 and 18 waist and hip circumference were measured, fasting blood samples were drawn and body composition was determined by underwater weighing. Twentyfour hour urine samples were collected at weeks 0 and 18 for nitrogen determination to check compliance to the protein intake. Previously, it has been reported that on average $24 \mathrm{~h}$ urine nitrogen is a constant proportion $( \pm 80 \%)$ of dietary nitrogen $(32)$. Therefore, 
we used the following formula to calculate the amount of proteins ingested during urine collection:

Grams protein ingested per day $=(\mathrm{g}$ urinary $\mathrm{N}+0.2 \mathrm{~g} *$ urinary $\mathrm{N}) * 6.25(32)$

This estimated amount of protein was multiplied by 4.2 to calculate the amount of energy (in kJ) subjects had ingested as proteins. By using subjects' daily energy intake as determined by 3-day food records, the contribution of protein intake to total energy intake was estimated.

\section{Anthropometric measures}

All subjects were weighed in underwear on the same decimal scale throughout the study (Seca, Model 861, Hamburg, Germany; accuracy of $0.1 \mathrm{~kg}$ ). Height was measured using a wall-mounted stadiometer (Seca, Model 225, Hamburg, Germany; accuracy of 1.0 $\mathrm{mm}$ ). Waist circumference was measured at the site of the smallest circumference between the rib cage and the ileac crest, with subjects in standing position. Hip circumference was measured at the site of the largest circumference between the waist and the thighs. Both waist and hip circumference were measured with an accuracy of $1.0 \mathrm{~mm}$. Waist-hip ratio was calculated by dividing waist circumference by hip circumference.

Body composition was determined by measuring body mass in air and underwater on a digital scale, accurate to $0.01 \mathrm{~kg}$ (Sauter type E1200, Ebingen, Germany). Lung volume was measured simultaneously with the helium dilution technique using a spirometer (Volugraph 2000, Mijnhardt, The Netherlands). Body density was used to calculate body fat according to the two-compartment model as described by Siri (33).

\section{Biochemical analysis}

Fasting blood samples were collected in EDTA containing tubes for glucose, insulin, glucagon, leptin, adiponectin, free fatty acids (FFA), triglycerides (TG) and HbA1c analyses. EDTA blood to which aprotinin $(5 \mathrm{kIU} / \mathrm{ml}$ blood; Sigma-Aldrich Chemie BV, Zwijndrecht, The Netherlands) was added was used for glucagon analysis. Whole blood samples were drawn for $\mathrm{HbA} 1 \mathrm{c}$ determination. The remainder of the blood sample was centrifuged at $1000 \mathrm{~g}$ at $4^{\circ} \mathrm{C}$ for $10 \mathrm{~min}$. Aliquots of plasma were frozen immediately in liquid nitrogen and stored at $-45^{\circ} \mathrm{C}$. Glucose, total cholesterol, HDL, LDL and triglycerides were analyzed by an enzymatic in vitro test on a Roche/Hitachi automated analyzer with Roche reagentia kits (Roche Diagnostics, Basel, Switzerland) and free fatty acids with reagentia kits from Wako (Wako Chemicals, Neuss, Germany). Insulin was analyzed by radioimmunoassay (Human Insulin Specific RIA kit, LINCO Research Inc., Missouri, USA), as was glucagon (Glucagon RIA kit, LINCO Research Inc., Missouri, USA). Leptin and adiponectin were analyzed using multiplexed sandwich 
immunoassays based on flowmetric Luminex ${ }^{\circledR}$ xMAP technology as described previously (34). HbA1c concentration was determined on a Tosoh analyzer by High Pressure Liquid Chromatography (Tosoh Bioscience Inc., South San Francisco, USA). HOMA index for insulin resistance (HOMAir) was calculated by the following formula: [glucose]*[insuline]/22.5 (35)

\section{Statistical analyses}

All data are presented as means \pm SEM. Changes from baseline (week 0) or from week 6 were calculated. Statistical analysis was performed using SPSS for Mac OS X software (SPSS, Chicago, IL). Differences between groups at baseline, week 6 and week 18 and differences in changes in weight loss (week 6 - week 0) and weight maintenance (week 18 - week 6) between groups were tested by one-way ANOVA with diet (HC vs HP) as factor and with HC and HPC or HC and HPW as factor. Changes within each group between week 0 and 6 , between week 6 and 18 and between week 0 and 18 were tested by paired-samples t-test analyses. Body weight changes and changes in systolic and diastolic blood pressure that occurred during the weight maintenance period (changes from week 6 to week 8, 10, 14 and 18) were analyzed using repeated measures ANOVA with changes over time as within-subject variables and group (HC vs HP; HC vs HPC; HC vs HPW) as between-subject variables. All statistical tests were performed two-tailed and a $\mathrm{p}$ value $<0.05$ was considered statistically significant.

Table 5.1 Basal subject characteristics

\begin{tabular}{lcccc}
\hline & Maltodextrin & Casein & Whey & P-value* \\
\hline $\mathrm{N}(\mathrm{M} / \mathrm{F})$ & $16(6 / 10)$ & $14(5 / 9)$ & $18(6 / 12)$ & 0.97 \\
Age $($ years $)$ & $46.0 \pm 2.2$ & $45.4 \pm 2.2$ & $44.9 \pm 2.0$ & 0.93 \\
$\mathrm{BW}(\mathrm{kg})$ & $97.8 \pm 4.0$ & $95.1 \pm 6.4$ & $96.4 \pm 3.0$ & 0.92 \\
$\mathrm{BMI}\left(\mathrm{kg} / \mathrm{m}^{2}\right)$ & $32.4 \pm 1.2$ & $32.9 \pm 1.6$ & $33.4 \pm 1.0$ & 0.84 \\
BF $(\%)$ & $39.2 \pm 1.9$ & $42.0 \pm 1.3$ & $41.2 \pm 1.4$ & 0.45 \\
Fat mass $(\mathrm{kg})$ & $38.5 \pm 2.8$ & $40.23 \pm 3.3$ & $39.65 \pm 2.0$ & 0.90 \\
Fat free mass $(\mathrm{kg})$ & $59.26 \pm 2.9$ & $54.82 \pm 3.60$ & $56.23 \pm 2.0$ & 0.54 \\
Waist $(\mathrm{cm})$ & $108.2 \pm 3.1$ & $108.5 \pm 4.4$ & $109.1 \pm 2.4$ & 0.98 \\
Hip $(\mathrm{cm})$ & $110.5 \pm 2.4$ & $112.0 \pm 2.6$ & $116.2 \pm 2.6$ & 0.24 \\
Glucose $(\mathrm{mM})$ & $5.4 \pm 0.1$ & $5.2 \pm 0.1$ & $5.5 \pm 0.1$ & 0.18 \\
HbA1c $(\%)$ & $5.42 \pm 0.07$ & $5.38 \pm 0.09$ & $5.40 \pm 0.09$ & 0.92 \\
Insulin $(\mu \mathrm{U} / \mathrm{mL})$ & $20.7 \pm 3.0$ & $15.7 \pm 1.8$ & $20.0 \pm 1.4$ & 0.25 \\
HOMAir index & $5.0 \pm 0.8$ & $3.6 \pm 0.5$ & $4.9 \pm 0.4$ & 0.19 \\
Glucagon $(\mathrm{pg} / \mathrm{mL})$ & $70.0 \pm 7.4$ & $69.1 \pm 5.6$ & $75.8 \pm 6.6$ & 0.74 \\
Total cholesterol $(\mathrm{mM})$ & $4.8 \pm 0.2$ & $4.9 \pm 0.2$ & $5.2 \pm 0.3$ & 0.45 \\
Triglycerides $(\mathrm{mM})$ & $1.6 \pm 0.3$ & $1.4 \pm 0.2$ & $1.7 \pm 0.2$ & 0.77 \\
Sys BP $(\mathrm{mm} \mathrm{Hg})$ & $135.6 \pm 4.4$ & $127.9 \pm 6.3$ & $130.4 \pm 3.9$ & 0.52 \\
Diast BP $(\mathrm{mm} \mathrm{Hg})$ & $87.9 \pm 11.4$ & $83.4 \pm 3.0$ & $84.2 \pm 2.2$ & 0.46 \\
\hline Values are means & & & &
\end{tabular}

Values are means \pm SEM

* P-values from one-way ANOVA 


\section{Results}

Baseline characteristics of the study population are shown in Table 5.1. The subgroups were well balanced for age, BMI, waist and hip circumference, blood pressure, fasting plasma glucose, cholesterol and triglycerides.

\section{Composition of the study diets and subject compliance}

The self-reported energy intake and macronutrient composition before the start of the study (week 0) and at the end of the weight maintenance period of the HC, HPC and HPW groups (week 18) are shown in Table 5.2. At the end of the intervention period the $\mathrm{HC}$ group reported to consume $63 \mathrm{En} \%$ carbohydrates and $16 \mathrm{En} \%$ proteins while both HP groups consumed approximately $35 \mathrm{En} \%$ proteins and $42 \mathrm{En} \%$ carbohydrates. Total energy intake was significantly lower compared to week 0 for all diets $(p<0.005)$ except HPC $(\mathrm{p}=0.226)$. HC and HP groups differed significantly from each other in carbohydrate intake and in protein intake $(\mathrm{p}<0.005)$ but not in fat intake. Carbohydrate supplements accounted for $\pm 6.5 \mathrm{En} \%$ of total carbohydrate intake in the HC group (thus $56.5 \mathrm{En} \%$ via diet, $6.5 \mathrm{En} \%$ via supplements) while protein supplements accounted for $10 \mathrm{En} \%$ of total protein intake $(24.5 \mathrm{En} \%$ via diet and $10 \mathrm{En} \%$ via supplements).

Table 5.2 Energy intake and macronutrient composition of the diets at the beginning (week 0) and at the end (week 18) of the study

\begin{tabular}{cccccc}
\hline & & En\% protein & En\% carbohydrate & En\% fat & Kcal/day \\
\hline \multirow{2}{*}{ WEEK } & HC & $16.0 \pm 0.8$ & $48.2 \pm 1.6$ & $34.9 \pm 1.4$ & $2398 \pm 141$ \\
0 & HP & $16.7 \pm 0.6$ & $44.3 \pm 1.0$ & $35.5 \pm 0.7$ & $2161 \pm 93$ \\
& Casein & $18.0 \pm 1.0$ & $44.4 \pm 1.7$ & $34.7 \pm 1.2$ & $2045 \pm 142$ \\
& Whey & $15.7 \pm 0.7$ & $44.1 \pm 1.3$ & $36.2 \pm 0.9$ & $2252 \pm 122$ \\
\hline \multirow{2}{*}{ WEEK* } & HC & $15.8 \pm 0.6$ & $62.7 \pm 2.4 \#$ & $21.2 \pm 1.5 \#$ & $1868 \pm 142 \#$ \\
& HP & $34.9 \pm 1.1 \#$ & $42.2 \pm 0.8$ & $24.0 \pm 1.1 \#$ & $1828 \pm 73 \#$ \\
& Casein & $34.5 \pm 1.3 \#$ & $42.3 \pm 1.2$ & $23.5 \pm 1.5 \#$ & $1848 \pm 108$ \\
\hline
\end{tabular}

HP results of complete high-protein diet group $(\mathrm{N}=32)$

* Including supplements

\# Significantly different from week 0 as determined by one-way ANOVA analysis $(\mathrm{p}<0.005)$

Urinary nitrogen at the end of the intervention was significantly higher in the HP groups compared to the HC group $(16.0 \pm 0.7 \mathrm{~g} / 24 \mathrm{~h}$ vs $9.8 \pm 0.9 \mathrm{~g} / 24 \mathrm{~h}, \mathrm{p}<0.001)$ and was similar for both protein groups $(16.5 \pm 1.0 \mathrm{~g} / 24 \mathrm{~h}$ vs $15.7 \pm 1.0$ for HPC and HPW respectively, NS). When estimating protein intake from $24 \mathrm{~h}$ urinary nitrogen excretion 
and total daily energy intake as determined from food records, subjects in the HC group consumed \pm 16.5 En\% proteins, while the HPC and HPW group consumed 28.1 and 27.2 En\% proteins. Although all subjects (independent of group) reported to have increased their physical activity $(\mathrm{p}=0.004)$, no differences in change in physical activity, as determined by the Baecke questionnaire, were found between groups $(p=0.63)$.

\section{Anthropometric measures and blood pressure}

Weight loss: VLCD induced similar weight (Figure 5.1A), fat mass and fat free mass loss, reductions of waist- and hip circumference and blood pressure in the HC and HP group (Table 5.3 and 5.4).
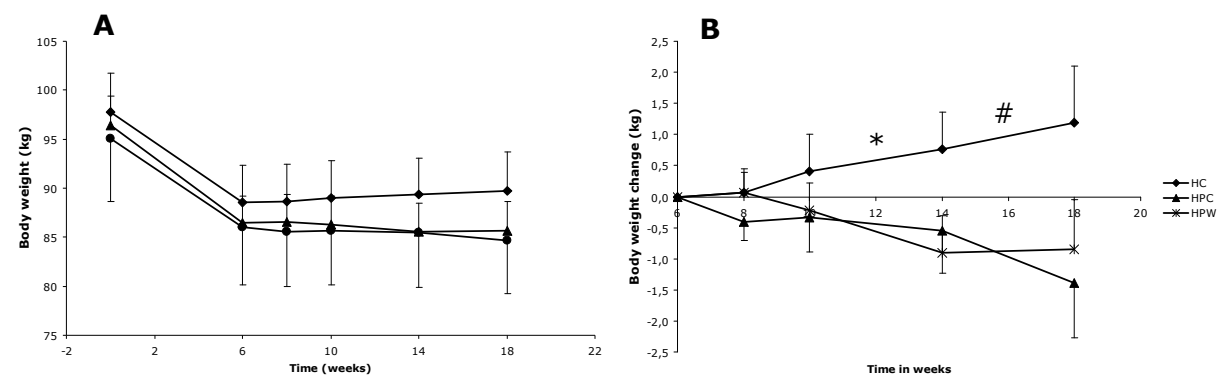

Figure 5.1

Mean body weight over time (A) and body weight change during weight maintenance (compared to immediately after weight loss) (B), according to study group

Weight maintenance: During weight maintenance subjects in the $\mathrm{HC}$ group gained, while subjects in both protein groups lost approximately an additional $1.0 \mathrm{~kg} \mathrm{BW}$ (Figure 5.1B). Repeated measures analysis showed a significant effect for the time-bytreatment interaction for body weight changes during weight maintenance $(p=0.01)$ when HC and HP were compared. A significant time-by-treatment effect was also found for both protein groups separately compared to the $\mathrm{HC}$ group $(\mathrm{p}=0.03$ and $\mathrm{p}=0.03$ for $\mathrm{HC}$ vs HPC and HC vs HPW, respectively). The change in BF \% (wk 18 - wk 6) was significantly different between the HC and HP group $(p=0.02)$ (Table 5.3). This difference was mainly due to a significant decrease in BF\% in HPW (HC vs HPW p = 0.01), while no significant difference was found for HPC (HC vs HPC; $p=0.17$ ) (Table 5.5). Waist circumference increased slightly in the HC group while it decreased in the $\mathrm{HP}$ group resulting in a significant difference between those groups $(\mathrm{p}=0.05)$. The change in waist circumference was significantly different between HC and HPC $(\mathrm{p}=$ 0.04 ) but not between HC and HPW ( $\mathrm{p}=0.14)$. 

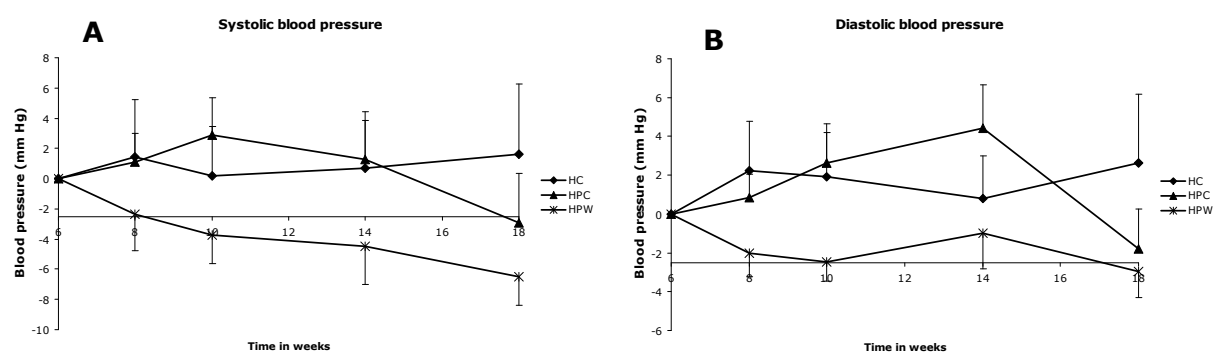

Figure 5.2

Changes in systolic (A) and diastolic (B) blood pressure during weight maintenance according to study group

No statistically significant differences were found between $\mathrm{HC}$ and HP groups or HC with HPC and HPW groups for changes in blood pressure, although there was some tendency for a more pronounced reduction in blood pressure in the HP group (systolic blood pressure $p=0.12$, diastolic blood pressure $p=0.09$ ) (Table 5.3 and 5.4). Although systolic blood pressure seemed to decrease in the HPW group rather consistently (Figure 5.2) there were no statistically significant effects of time, treatment or their interaction when comparing $\mathrm{HC}$ with $\mathrm{HPW}(\mathrm{p}=0.75, \mathrm{p}=0.66$ and $\mathrm{p}=0.14$, respectively). This was also the case for HC compared with $\mathrm{HP}(\mathrm{p}=0.73, \mathrm{p}=0.68$ and $p=0.91$, respectively), or HC compared with $\mathrm{HPC}(\mathrm{p}=0.68, \mathrm{p}=0.43$ and $\mathrm{p}=0.29$, respectively). Also for changes in diastolic blood pressure no statistically significant differences were found for time, treatment or time-by-treatment when comparing $\mathrm{HC}$ with HP ( $p=0.87, p=0.29$ and $p=0.18$, respectively), HC with HPC $(p=0.63, p=$ 0.24 and $p=0.88$, respectively) or when comparing HC with HPW ( $p=0.99, p=0.69$ and $\mathrm{p}=0.05$, respectively), although in the latter comparison the interaction term only just failed to reach statistical significance.

The increase in HDL cholesterol was found to be more pronounced in the HP than in the HC group, although not significantly $(\mathrm{p}=0.08$ ) (Table 5.4). The change in LDL:HDL ratio was not significantly different between $\mathrm{HC}$ and $\mathrm{HP}(\mathrm{p}=0.15$, table 5.4), but it decreased significantly in HPC compared to HC ( $\mathrm{p}=0.03$, table 5.4 and 5.5). The HC diet induced a higher increase in TG than the HP diet $(\mathrm{p}=0.01)$ with similar tendencies in both protein groups (HPC p $=0.07$, HPW $=0.06$ ) (tables 5.4 and 5.5), but no difference was found for FFA concentrations $(\mathrm{p}=0.55)$. Concerning leptin and adiponectin concentrations, no differences were found between the HC and HP diet groups (Table 5.3 and 5.4). 


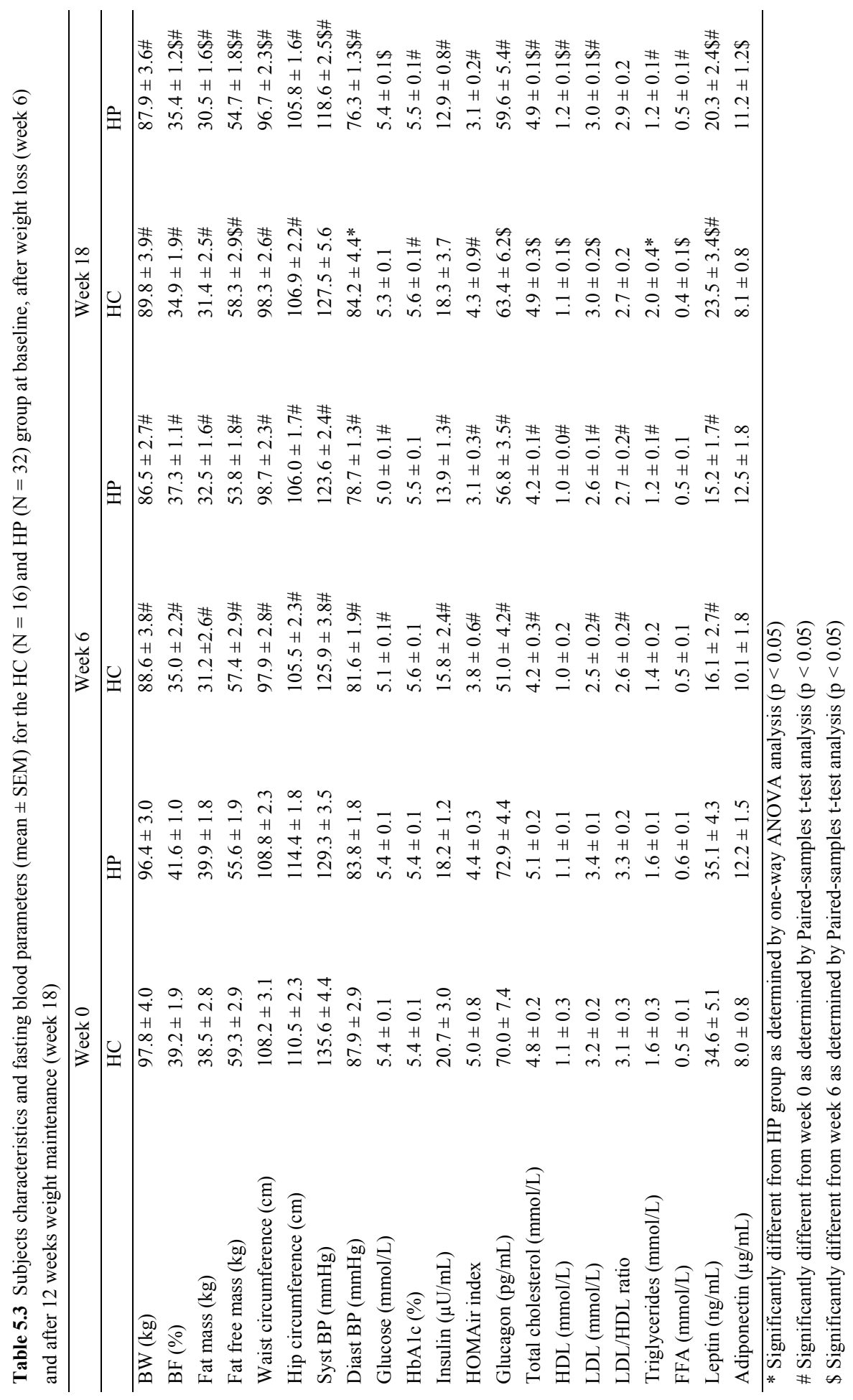




\section{Fasting glucose, insulin, glucagon, HOMA, leptin, adiponectin and blood lipids}

Weight loss: Tables 5.3 and 5.4 show how weight loss influenced fasting blood parameters in the HC and HP group. HbA1c, HDL cholesterol, TG, FFA and adiponectin levels did not change significantly with weight loss in the HC group. $\mathrm{HbA1c}$, FFA and adiponectin levels did not change significantly in the HP group. When analyzing the effect of weight loss for all subjects together a significant decrease was found in all plasma lipids $(\mathrm{p} \leq 0.001)$ except free fatty acids $(\mathrm{p}=0.07)$. Furthermore, plasma glucose, insulin, glucagon and leptin concentrations and LDL:HDL ratio were significantly reduced $(\mathrm{p}<0.001)$. Also HbA1c had decreased significantly $(\mathrm{p}=0.03)$, while the increase in adiponectin did not reach statistical significance $(p=0.23)$.

Weight maintenance: When comparing changes from week 6 to week 18 in the HC and HP group fasting glucose concentrations increased significantly more in the HP group $(\mathrm{p}=0.02)$. The difference was statistically significant when comparing HC with HPW $(p=0.01)$, but not when comparing HC with HPC $(p=0.20)$ (Table 5.5). Differences in fasting insulin changes between the $\mathrm{HC}$ and $\mathrm{HP}$ groups did not reach statistical significance $(\mathrm{p}=0.10)$ (Table 5.3, 5.4 and 5.5). Fasting glucagon concentrations increased significantly on the HC diet compared to the HP diet $(\mathrm{p}=0.02)$ (Table 5.3). Changes in plasma glucagon concentrations were borderline significant when comparing HC with HPC $(\mathrm{p}=0.053)$ or HPW $(\mathrm{p}=0.055)$ (Table 5.4 and 5.5). Changes in fasting total cholesterol were not different between both diet groups $(p=0.43)$. In both groups a similar increase in LDL cholesterol was found. 


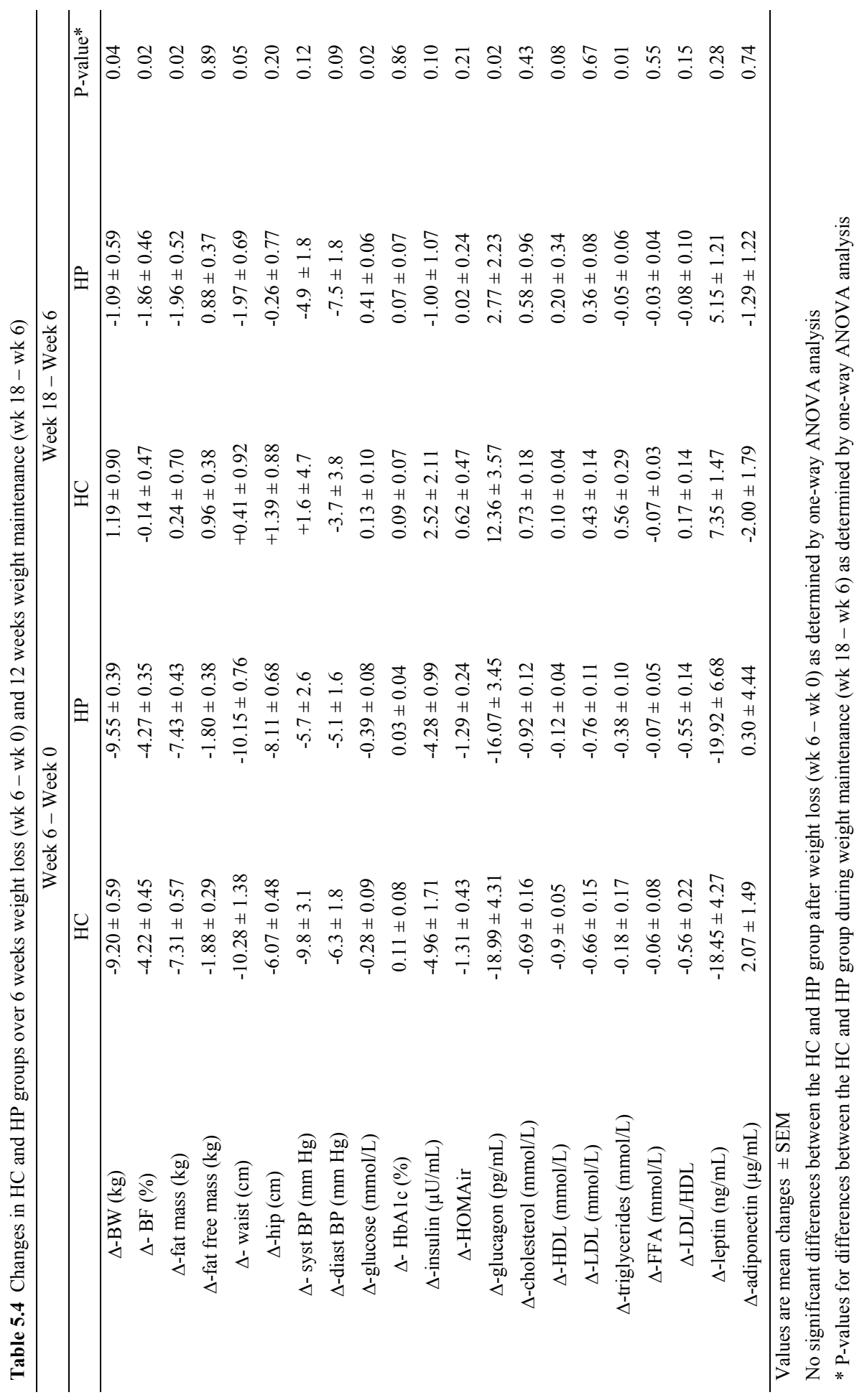




\section{Discussion}

The major findings of the present study are that, after an initial substantial weight loss, a high-protein, low-fat diet prevented weight regain and initiated even further weight loss compared to a high-carbohydrate, low-fat diet. Furthermore, the high-protein diets resulted in additional fat mass loss, lower increase in fasting triglyceride and glucagon concentrations but more pronounced increase in glucose concentration during the weight maintenance phase compared to the $\mathrm{HC}$ diet.

As Table 5.2 shows, we were successful in increasing carbohydrate intake in the $\mathrm{HC}$ group to $62 \mathrm{En} \%$ and protein intake in the HPC and HPW groups to $35 \mathrm{En} \%$, as calculated from 3-day food records. Although we tried to guide all subjects towards 30 $\mathrm{En} \%$ fat intake, it was reduced in all groups to slightly above $20 \mathrm{En} \%$. Therefore, protein intake in the $\mathrm{HC}$ group still accounted for $16 \mathrm{En} \%$ of total energy intake. When comparing reported protein intake with protein intake calculated from urinary nitrogen excretion subjects seemed to have over-reported their protein intake and this mainly in both HP groups. However, the difference in protein intake between the HC and HP group is likely to have been at least $10 \mathrm{En} \%$.

The amount of weight loss after the VLCD was similar in the HC and HP group as were the changes in other anthropometric measures and blood parameters (Table 5.3), despite the fact that subjects were already on different diets for 1 week when week 6 measurements were done. This suggests no important acute effects of the diets on variables measured. The effect of weight loss on fasting glucose, insulin, HbAlc and blood lipids has been studied extensively before, as reviewed by Manco and Mingrone (2005) (36) and Noakes and Clifton (2000) (37). Our results are in line with these findings. To our knowledge, the effect of weight loss on fasting glucagon levels has not been studied before.

We found plasma glucagon levels to be reduced after weight loss independent of diet. Whether the change in plasma glucagon is the result of weight loss or of the negative energy balance that subjects might still have been in is unclear. 


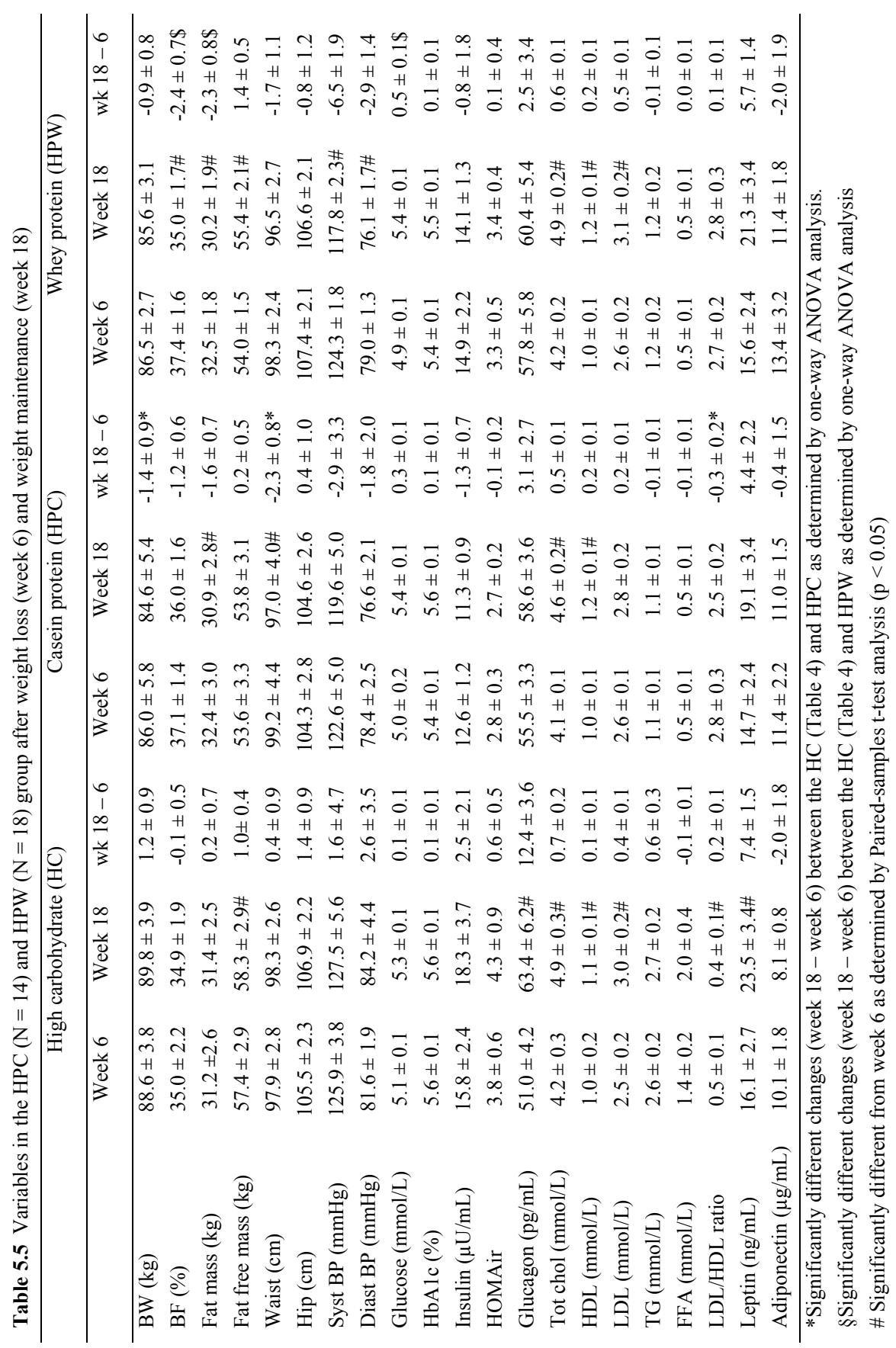


The difference in BW change during weight maintenance between the HP and HC groups was mainly caused by the further reduction in FM in the HP group. Although the change in BW was more pronounced in the HPC than HPW group, subjects in the HPW group had a more pronounced reduction in $\mathrm{BF} \%$ than those in the HPC group, while we did not find significant differences in fat free mass when comparing HPC and HPW with the HC group. This is remarkable since after VLCD subjects normally regain weight. This indicates that a substantial increase in dietary protein does significantly contribute to weight management and this by preserving fat free mass. The difference in BW loss cannot be attributed to a stronger reduction in reported total energy intake (EI) in the HP group or by an increase in physical activity as determined by the Baecke questionnaire since subjects reported to have increased their physical activity $(\mathrm{p}=$ $0.004)$ independent of diet $(\mathrm{p}=0.88)$. Previous research showed that HP diets are more satiating than $\mathrm{HC}$ diets $(4,6,7,9)$. We did not find significant differences in total EI between groups, but 3-day food records are relatively crude measures and too insensitive to pick up relatively small differences in total EI. Furthermore, macronutrient-specific over- and underreporting can also not be excluded as was demonstrated in obese subjects by Goris and colleagues (38). Furthermore, an increase in energy expenditure related to elevated protein synthesis in the HP group $(39,40)$ (Chapter 4) and the high metabolic cost of metabolizing protein (41) might have contributed to the difference in BW change between the HP and HC diet.

Other studies looking at weight maintenance over 3 to 6 months after weight loss reported weight regain both in the control (15 En\% protein) (2.0 and $3.0 \mathrm{~kg}$ during 3 and 6 months weight maintenance, respectively) and in the protein supplemented group (18 En\% protein) (1.0 and $0.8 \mathrm{~kg}$ during 3 and 6 months weight maintenance, respectively), although weight regain in the protein supplemented group was lower (6, 7) which is in agreement with this study. In the present study subjects were instructed to consume $50 \mathrm{~g}$ extra protein or maltodextrin by means of supplements and they received dietary counseling to exchange part of their daily carbohydrate intake for proteins and visa versa with a similar fat intake in an ad libitum situation. In the studies by Westerterp and colleagues $(6,7)$ subjects in the protein group received protein supplements (Ca-caseinate $\pm 30 \mathrm{~g} / \mathrm{d}$ ) but no placebo was used in the control group and subjects were asked to adhere to their habitual diet in all groups. No information about carbohydrate or fat content of their diets is available, so differences in fat and/or carbohydrate intake may have contributed to the effects observed in these studies. In particular changes in ad libitum fat intake have a considerable impact on body weight changes as described previously (42). Subjects in the HPC lost slightly more weight during the weight maintenance phase of the study than subjects in the HPW group, 
resulting in a statistically significant difference in body weight change during weight maintenance between HC and HPC group ( $p=0.05)$, but not between the HC and HPW groups $(p=0.10)$. Casein is a slow digestible protein while whey is a fast digestible protein. Boirie and colleagues introduced the concept of fast and slow digestible proteins where fast proteins are soluble and slow proteins form clots in the stomach resulting in a slower release of amino acids (25). Calbet and Holst (2004), on the other hand, showed that ingestion of casein, a slow protein, did not induce a difference in gastric emptying as compared to whey protein (fast protein) (43) but still did elicit a slower increase and reduced plasma amino acid levels $(43,44)$. Lacroix et al (2006) also found that amino acid kinetics are different for fast and slow proteins (27). Furthermore, plasma amino acid levels are found to be associated with satiety $(28,45)$. If slow proteins indeed clot in the stomach and cause prolonged gastric extension, one would expect increased satiety and reduced EI in the HPC group as compared to the HPW group. If, on the other hand, increased plasma amino acid responses induce higher satiety and reduced EI, one would expect increased satiety and reduced EI in the HPW group. Our data on body weight changes tend to support this first possibility, although larger studies will be necessary to provide more conclusive evidence.

During weight maintenance, no significant differences in HOMA index for insulin resistance, adiponectin or HbAlc between the $\mathrm{HC}$ and $\mathrm{HP}$ diet groups were found. This suggests that in healthy obese subjects insulin sensitivity is not substantially influenced by protein or carbohydrate intake within the limits of this study. Plasma glucagon levels did not change in the HP diet group but increased significantly in the HC diet group while no significant changes in insulin levels were found. Insulin and glucagon are counter-regulatory hormones regarding glucose metabolism (46) and hyperglycemia associated with type 2 diabetes is thought to be a result of a reduced suppression of glucagon due to relative insulin deficiency (47-49). Henkel et al (2005) reported similar fasting glucose and insulin concentrations in normal glucose tolerant (NGT) and impaired glucose tolerant (IGT) subjects but significantly higher fasting glucagon concentrations in IGT compared to NGT and type 2 diabetes mellitus (T2DM) subjects (49). Whether chronically increased fasting glucagon levels on a HC diet might be involved in the development of impaired glucose tolerance and insulin sensitivity remains to be determined.

When looking at changes in lipid profiles the $\mathrm{HC}$ diet induced a significantly higher increase in triglycerides than the HP diet. This is in agreement with the shorttime study reported by Dumesnil and colleagues who found that during an ad libitum high-protein low-glycemic index diet (31 En\% protein and $37 \mathrm{En} \%$ carbohydrate) of 6 days plasma triglyceride levels decreased while they increased during an ad libitum high-carbohydrate diet (15 En\% protein. $55 \mathrm{En} \%$ protein) (50). This effect might, 
though, partly be caused by differences in body weight changes induced by both diets (50), although the increasing effect of $\mathrm{HC}$ diets on plasma triglycerides has been described before (51). Also in a setting in which BW is kept constant a beneficial effect of $\mathrm{HP}$ over $\mathrm{HC}$ diets on triglyceride levels has been described (52). Although the latter study also revealed reduced LDL and HDL cholesterol levels in the HP compared to the HC diet group (52), we found no effect on LDL cholesterol and a trend towards increased HDL cholesterol levels in the HP group. Interestingly, this effect on HDL cholesterol, although not statistically significant, seemed only to be present in the HPC vs HC group. This resulted in a significantly decrease in LDL:HDL ratio in the HPC compared to HC group. Therefore, the effect of proteins on HDL cholesterol can be influenced by protein source. This might explain why inconclusive results regarding the effect of high-protein diets on HDL cholesterol exist in both energy restricted and $a d$ libitum diets $(19,50,52,53)$.

Regarding blood pressure, the difference in changes in diastolic blood pressure tended to be significant when comparing HPW with $\mathrm{HC}$ while we did not find an effect of diet on systolic blood pressure. A recent review indicates that protein intake is inversely related with blood pressure (54). Especially milk proteins may be effective in lowering blood pressure (55). The lack of a statistically significant effect of our HP diets on blood pressure may be due to the fact that blood pressure was already significantly reduced by the weight loss when the randomized intervention started and the relatively small size of the study.

In conclusion the present study shows that a high-protein diet results in a better maintenance of weight loss induced by a very low calorie diet than a high-carbohydrate diet. This effect was caused by a reduction in fat mass in both HP groups, although this effect was more pronounced in the HPW group, while fat free mass was preserved. Furthermore, fasting triglyceride and glucagon concentrations decreased more during weight maintenance in the HP groups, while plasma glucose increased more in the HP vs HC group. Finally, HPC but not HPW improved LDL:HDL ratio as compared with the $\mathrm{HC}$ diet.

\section{Acknowledgements}

This work was supported by Kerry Bio-Science, Almere, The Netherlands. The authors would like to thank Dr. W. Calame and Dr. A.D. Siemensma from Kerry Bioscience for their contributions and fruitful discussions. 


\section{References}

1. Harder, H., Dinesen, B. \& Astrup, A. (2004) The effect of a rapid weight loss on lipid profile and glycemic control in obese type 2 diabetic patients. Int J Obes Relat Metab Disord 28: 180-182.

2. Henry, R. R., Wiest-Kent, T. A., Scheaffer, L., Kolterman, O. G. \& Olefsky, J. M. (1986) Metabolic consequences of very-low-calorie diet therapy in obese non-insulin-dependent diabetic and nondiabetic subjects. Diabetes 35: 155-164.

3. Due, A., Toubro, S., Skov, A. R. \& Astrup, A. (2004) Effect of normal-fat diets, either medium or high in protein, on body weight in overweight subjects: a randomised 1-year trial. Int J Obes Relat Metab Disord 28: 1283-1290.

4. Skov, A. R., Toubro, S., Ronn, B., Holm, L. \& Astrup, A. (1999) Randomized trial on protein vs carbohydrate in ad libitum fat reduced diet for the treatment of obesity. Int J Obes Relat Metab Disord 23: 528-536.

5. Westerterp-Plantenga, M. S. (2003) The significance of protein in food intake and body weight regulation. Curr Opin Clin Nutr Metab Care 6: 635-638.

6. Westerterp-Plantenga, M. S., Lejeune, M. P., Nijs, I., van Ooijen, M. \& Kovacs, E. M. (2004) High protein intake sustains weight maintenance after body weight loss in humans. Int J Obes Relat Metab Disord 28: 57-64.

7. Lejeune, M. P., Kovacs, E. M. \& Westerterp-Plantenga, M. S. (2005) Additional protein intake limits weight regain after weight loss in humans. Br J Nutr 93: 281-289.

8. Lejeune, M. P., Westerterp, K. R., Adam, T. C., Luscombe-Marsh, N. D. \& Westerterp-Plantenga, M. S. (2006) Ghrelin and glucagon-like peptide 1 concentrations, 24-h satiety, and energy and substrate metabolism during a high-protein diet and measured in a respiration chamber. Am J Clin Nutr 83: 89-94.

9. Weigle, D. S., Breen, P. A., Matthys, C. C., Callahan, H. S., Meeuws, K. E., Burden, V. R. \& Purnell, J. Q. (2005) A high-protein diet induces sustained reductions in appetite, ad libitum caloric intake, and body weight despite compensatory changes in diurnal plasma leptin and ghrelin concentrations. Am J Clin Nutr 82: 41-48.

10. van Loon, L. J., Saris, W. H., Verhagen, H. \& Wagenmakers, A. J. (2000) Plasma insulin responses after ingestion of different amino acid or protein mixtures with carbohydrate. Am J Clin Nutr 72: 96-105.

11. Manders, R. J., Wagenmakers, A. J., Koopman, R., Zorenc, A. H., Menheere, P. P., Schaper, N. C., Saris, W. H. \& van Loon, L. J. (2005) Co-ingestion of a protein hydrolysate and amino acid mixture with carbohydrate improves plasma glucose disposal in patients with type 2 diabetes. Am J Clin Nutr 82: 76-83.

12. Calbet, J. A. \& MacLean, D. A. (2002) Plasma glucagon and insulin responses depend on the rate of appearance of amino acids after ingestion of different protein solutions in humans. J Nutr 132: 21742182.

13. Kabadi, U. M. (1991) Dose-kinetics of pancreatic alpha- and beta-cell responses to a protein meal in normal subjects. Metabolism 40: 236-240.

14. Westphal, S. A., Gannon, M. C. \& Nuttall, F. Q. (1990) Metabolic response to glucose ingested with various amounts of protein. Am J Clin Nutr 52: 267-272.

15. Nuttall, F. Q. \& Gannon, M. C. (2004) Metabolic response of people with type 2 diabetes to a high protein diet. Nutr Metab (Lond) 1: 6.

16. Baba, N. H., Sawaya, S., Torbay, N., Habbal, Z., Azar, S. \& Hashim, S. A. (1999) High protein vs high carbohydrate hypoenergetic diet for the treatment of obese hyperinsulinemic subjects. Int J Obes Relat Metab Disord 23: 1202-1206. 
17. Piatti, P. M., Monti, F., Fermo, I., Baruffaldi, L., Nasser, R., Santambrogio, G., Librenti, M. C., GalliKienle, M., Pontiroli, A. E. \& Pozza, G. (1994) Hypocaloric high-protein diet improves glucose oxidation and spares lean body mass: comparison to hypocaloric high-carbohydrate diet. Metabolism 43: 1481-1487.

18. Samaha, F. F., Iqbal, N., Seshadri, P., Chicano, K. L., Daily, D. A., McGrory, J., Williams, T., Williams, M., Gracely, E. J. \& Stern, L. (2003) A low-carbohydrate as compared with a low-fat diet in severe obesity. N Engl J Med 348: 2074-2081.

19. Farnsworth, E., Luscombe, N. D., Noakes, M., Wittert, G., Argyiou, E. \& Clifton, P. M. (2003) Effect of a high-protein, energy-restricted diet on body composition, glycemic control, and lipid concentrations in overweight and obese hyperinsulinemic men and women. Am J Clin Nutr 78: 31-39.

20. Layman, D. K., Shiue, H., Sather, C., Erickson, D. J. \& Baum, J. (2003) Increased dietary protein modifies glucose and insulin homeostasis in adult women during weight loss. J Nutr 133: 405-410.

21. McCarty, M. F. (1999) Vegan proteins may reduce risk of cancer, obesity, and cardiovascular disease by promoting increased glucagon activity. Med Hypotheses 53: 459-485.

22. Hubbard, R., Kosch, C. L., Sanchez, A., Sabate, J., Berk, L. \& Shavlik, G. (1989) Effect of dietary protein on serum insulin and glucagon levels in hyper- and normocholesterolemic men. Atherosclerosis 76: $55-61$.

23. Sanchez, A. \& Hubbard, R. W. (1991) Plasma amino acids and the insulin/glucagon ratio as an explanation for the dietary protein modulation of atherosclerosis. Med Hypotheses 36: 27-32.

24. Torres, N., Torre-Villalvazo, I. \& Tovar, A. R. (2006) Regulation of lipid metabolism by soy protein and its implication in diseases mediated by lipid disorders. J Nutr Biochem 17: 365-373.

25. Boirie, Y., Dangin, M., Gachon, P., Vasson, M. P., Maubois, J. L. \& Beaufrere, B. (1997) Slow and fast dietary proteins differently modulate postprandial protein accretion. Proc Natl Acad Sci U S A 94: 14930-14935.

26. Mahe, S., Roos, N., Benamouzig, R., Davin, L., Luengo, C., Gagnon, L., Gausserges, N., Rautureau, J. \& Tome, D. (1996) Gastrojejunal kinetics and the digestion of [15N]beta-lactoglobulin and casein in humans: the influence of the nature and quantity of the protein. Am J Clin Nutr 63: 546-552.

27. Lacroix, M., Bos, C., Leonil, J., Airinei, G., Luengo, C., Dare, S., Benamouzig, R., Fouillet, H., Fauquant, J. et al. (2006) Compared with casein or total milk protein, digestion of milk soluble proteins is too rapid to sustain the anabolic postprandial amino acid requirement. Am J Clin Nutr 84: 1070-1079.

28. Hall, W. L., Millward, D. J., Long, S. J. \& Morgan, L. M. (2003) Casein and whey exert different effects on plasma amino acid profiles, gastrointestinal hormone secretion and appetite. Br J Nutr 89: 239-248.

29. Crovetti, R., Porrini, M., Santangelo, A. \& Testolin, G. (1998) The influence of thermic effect of food on satiety. Eur J Clin Nutr 52: 482-488.

30. Moran, T. H., Ladenheim, E. E. \& Schwartz, G. J. (2001) Within-meal gut feedback signaling. Int J Obes Relat Metab Disord 25 Suppl 5: S39-41.

31. Baecke, J. A., Burema, J. \& Frijters, J. E. (1982) A short questionnaire for the measurement of habitual physical activity in epidemiological studies. Am J Clin Nutr 36: 936-942.

32. Bingham, S. A. (2003) Urine nitrogen as a biomarker for the validation of dietary protein intake. J Nutr 133 Suppl 3: 921S-924S.

33. Siri, W. E. (1993) Body composition from fluid spaces and density: analysis of methods. 1961. Nutrition 9: 480-491; discussion 480, 492.

34. Skogstrand, K., Thorsen, P., Norgaard-Pedersen, B., Schendel, D. E., Sorensen, L. C. \& Hougaard, D. M. (2005) Simultaneous measurement of 25 inflammatory markers and neurotrophins in neonatal dried blood spots by immunoassay with xMAP technology. Clin Chem 51: 1854-1866. 
35. Matthews, D. R., Hosker, J. P., Rudenski, A. S., Naylor, B. A., Treacher, D. F. \& Turner, R. C. (1985) Homeostasis model assessment: insulin resistance and beta-cell function from fasting plasma glucose and insulin concentrations in man. Diabetologia 28: 412-419.

36. Manco, M. \& Mingrone, G. (2005) Effects of weight loss and calorie restriction on carbohydrate metabolism. Curr Opin Clin Nutr Metab Care 8: 431-439.

37. Noakes, M. \& Clifton, P. M. (2000) Weight loss and plasma lipids. Curr Opin Lipidol 11: 65-70.

38. Goris, A. H., Westerterp-Plantenga, M. S. \& Westerterp, K. R. (2000) Undereating and underrecording of habitual food intake in obese men: selective underreporting of fat intake. Am J Clin Nutr 71: 130-134.

39. Robinson, S. M., Jaccard, C., Persaud, C., Jackson, A. A., Jequier, E. \& Schutz, Y. (1990) Protein turnover and thermogenesis in response to high-protein and high-carbohydrate feeding in men. Am J Clin Nutr 52: 72-80.

40. Claessens, M., Calame, W., Siemensma, A. D., Saris, W. H. M. \& van Baak, M. A. (2007) The thermogenic and metabolic effect of protein hydrolysate with or without a carbohydrate load in healthy male subjects. Metabolism 56: 1051-1059.

41. Stock, M. J. (1999) Gluttony and thermogenesis revisited. Int J Obes Relat Metab Disord 23: 1105-1117.

42. Astrup, A., Grunwald, G. K., Melanson, E. L., Saris, W. H. \& Hill, J. O. (2000) The role of low-fat diets in body weight control: a meta-analysis of ad libitum dietary intervention studies. Int J Obes Relat Metab Disord 24: 1545-1552.

43. Calbet, J. A. \& Holst, J. J. (2004) Gastric emptying, gastric secretion and enterogastrone response after administration of milk proteins or their peptide hydrolysates in humans. Eur J Nutr 43: 127-139.

44. Mahe, S., Huneau, J. F., Marteau, P., Thuillier, F. \& Tome, D. (1992) Gastroileal nitrogen and electrolyte movements after bovine milk ingestion in humans. Am J Clin Nutr 56: 410-416.

45. Mellinkoff, S. M., Frankland, M., Boyle, D. \& Greipel, M. (1956) Relationship between serum amino acid concentration and fluctuations in appetite. J Appl Physiol 8: 535-538.

46. Jiang, G. \& Zhang, B. B. (2003) Glucagon and regulation of glucose metabolism. Am J Physiol Endocrinol Metab 284: E671-678.

47. Fanelli, C. G., Porcellati, F., Rossetti, P. \& Bolli, G. B. (2006) Glucagon: the effects of its excess and deficiency on insulin action. Nutr Metab Cardiovasc Dis 16 Suppl 1: S28-34.

48. Shah, P., Basu, A., Basu, R. \& Rizza, R. (1999) Impact of lack of suppression of glucagon on glucose tolerance in humans. Am J Physiol 277: E283-290.

49. Henkel, E., Menschikowski, M., Koehler, C., Leonhardt, W. \& Hanefeld, M. (2005) Impact of glucagon response on postprandial hyperglycemia in men with impaired glucose tolerance and type 2 diabetes mellitus. Metabolism 54: 1168-1173.

50. Dumesnil, J. G., Turgeon, J., Tremblay, A., Poirier, P., Gilbert, M., Gagnon, L., St-Pierre, S., Garneau, C., Lemieux, I. et al. (2001) Effect of a low-glycaemic index--low-fat--high protein diet on the atherogenic metabolic risk profile of abdominally obese men. Br J Nutr 86: 557-568.

51. Parks, E. J. \& Parks, E. J. (2002) Changes in fat synthesis influenced by dietary macronutrient content. Proc Nutr Soc 61: 281-286.

52. Appel, L. J., Sacks, F. M., Carey, V. J., Obarzanek, E., Swain, J. F., Miller, E. R., 3rd, Conlin, P. R., Erlinger, T. P., Rosner, B. A. et al. (2005) Effects of protein, monounsaturated fat, and carbohydrate intake on blood pressure and serum lipids: results of the OmniHeart randomized trial. Jama 294: 24552464.

53. Meckling, K. A. \& Sherfey, R. (2007) A randomized trial of a hypocaloric high-protein diet, with and without exercise, on weight loss, fitness, and markers of the Metabolic Syndrome in overweight and obese women. Appl Physiol Nutr Metab 32: 743-752.

54. Myers, V. H. \& Champagne, C. M. (2007) Nutritional effects on blood pressure. Curr Opin Lipidol 18: 20-24. 
Chapter 5

55. Jauhiainen, T. \& Korpela, R. (2007) Milk peptides and blood pressure. J Nutr 137: 825S-829S. 


\section{Chapter 6}

\section{The influence of habitual diet on responses to a high-protein meal}

Mandy Claessens, Wim HM Saris, Sandy Monsheimer, Marleen A van Baak

Nutrition and Toxicology Research Institute Maastricht (NUTRIM), Department of Human Biology, Maastricht University, Maastricht, The Netherlands

This work was supported by Kerry Bio-Science, Almere, The Netherlands

Submitted 


\begin{abstract}
Background: High-protein diets are beneficial for weight loss and weight maintenance. The effect of long-term high-protein diets on the postprandial response to a high protein meal have not been studied.

Aim: This study investigated the effect of two ad libitum diets, one high in carbohydrate (HC) and one high in protein (HP) on postprandial responses in overweight and obese subjects.

Design: Twenty subjects participating in a long-term dietary intervention study, in which they were, after an initial 6-week weight loss period, assigned to an ad libitum high-protein $(\mathrm{N}=14)$ or high-carbohydrate diet $(\mathrm{N}=6)$ for 12 weeks, underwent a high-protein (35 En\%) meal tolerance test in the beginning and at the end of the intervention period. Blood was sampled for 3 hours for glucose, insulin, glucagon, free fatty acid and triglyceride determination, and at the same time points, appetite and satiety was measured by means of visual analogue scales.
\end{abstract}

Results: In the HP group postprandial area under the curve (AUC) for insulin was significantly lower at the end of the intervention than at the beginning. No change was found in the HC group. AUC for glucose, triglycerides and glucagon, and appetite ratings did not change significantly in either group.

Conclusion: Habitual consumption of a high-protein diet in the present study resulted in a reduced insulin response to a high protein meal. This indicates an improvement of the insulin sensitivity since the glucose response was not affected. No indications that long-term high-protein consumption reduces the satiating effect of a high-protein meal were found. 


\section{Introduction}

High-protein diets have beneficial effects on body weight and body composition, effects that might be related to the insulin- and glucagon-stimulating effect of proteins $(1,2)$. Dietary proteins induce glucagon and insulin secretion mainly through a direct effect of amino acids on pancreatic $\alpha$ - and $\beta$-cells (3-5). Both insulin and glucagon are involved in glucose metabolism. Postprandial insulin recruits GLUT 4 transporters to the cell membrane of mainly muscle cells and adipocytes and increases the intrinsic activity of this glucose transporter (6). Therefore, the main function of postprandial insulin is to improve glucose uptake and to lower plasma glucose levels. During fasting and hypoglycemia plasma glucagon increases plasma glucose concentrations by stimulating gluconeogenesis and glycogenolysis $(7,8)$. The precise role of postprandial glucagon changes remains to be elucidated. It has been suggested that glucagon induces lipolysis in human adipocytes $(9,10)$ but conflicting results have been reported $(11,12)$. Also the contribution of glucagon to the beneficial effect of a reduced postprandial insulin/glucagon ratio on cholesterol metabolism (13-15) remains to be investigated. Although the function of postprandial glucagon is not clear yet, Henkel and colleagues (16) showed that next to a reduced postprandial insulin response, subjects with type 2 diabetes also have increased postprandial glucagon responses suggesting that both insulin and glucagon responses might be of importance in relation to type 2 diabetes. While the carbohydrate-induced insulin response is clearly reduced in type 2 diabetic subjects, co-ingestion of protein has been found to improve the postprandial insulin response (17-19). Furthermore, replacing carbohydrates by protein in the diet of type 2 diabetic subjects for 4 to 6 weeks improves 24h glucose levels (20-25). Although it remains unclear whether the protein-induced glucagon response influences insulin sensitivity, it is of importance to know how a long-term high-protein diet affects postprandial insulin and glucagon stimulation after an acute high-protein meal. If longterm consumption of high-protein meals results in adaptation in insulin- and/or glucagon stimulation by proteins, which has been described for their satiating effect (26), the use of long-term high-protein diets in obese subjects might have to be reconsidered.

The aim of the present study was to investigate the effects of two ad libitum diets, one high in carbohydrate and one high in dietary protein with similar fat intake on postprandial responses of insulin, glucagon, glucose and triglycerides to a high-protein meal in healthy overweight and obese subjects. Furthermore, we wanted to investigate whether subjective satiety ratings induced by a high-protein meal change due to habitual high-protein intake. Our hypothesis is that if habitual consumption of high-protein 
meals results in adaptation, postprandial satiety, hormonal and metabolic responses to a high-protein meal will be lower with habitual high protein intake compared to habitual high carbohydrate intake.

\section{Subjects and Methods}

\section{Subjects}

This study is part of a larger study which is described in detail elsewhere (Chapter 5). After a 6-week weight loss (VLCD, Modifast, Novartis Nutrition, Belgium) period, 54 subjects took part in a 12-week weight maintenance (WM) study comparing a highcarbohydrate (HC), high-protein casein (HPC) or high-protein whey (HPW) diet. Subjects were allowed to eat ad libitum but received dietary counseling from a dietician in order to achieve a fat intake of maximally $30 \mathrm{En} \%$ in all groups and a carbohydrate intake of at least $55 \mathrm{En} \%$ in the $\mathrm{HC}$ group and a protein intake of at least $25 \mathrm{En} \%$ in both high-protein groups. Furthermore, subjects were asked to consume daily maltodextrin (HC) (AVB, Veendam, The Netherlands), casein (HPC) (Kerry Ingredients, Tralee, Ireland) or whey (HPW) (Carberry, Cork, Ireland) supplements (50 $\mathrm{g}$ /day). To determine energy and macronutrient intake, subjects filled in a 3-day food record ( 2 weekdays and 1 weekend day) at the end of the study. A subpopulation of 24 subjects participated in the present study, 8 in each dietary group. Of these 24 subjects, 20 completed the study. The 4 non-completers ( 2 from the HC and 2 from the HPC group) dropped out during the weight maintenance period due to personal family-related problems. All subjects gave their written informed consent and the study was approved by the Medical Ethics Committee of the Academic Hospital in Maastricht.

\section{Experimental design}

Subjects underwent a 3-h meal tolerance test (MTT) after 2 weeks and after 12 weeks on the respective diets in the weight maintenance phase. Test meals (composed of local breakfast products) consisted of $35 \mathrm{EN} \%$ protein, $30 \mathrm{EN} \%$ fat and $35 \mathrm{EN} \%$ carbohydrates. Total energy content of the meal was calculated for all subjects individually as $35 \%$ of 24 hour resting energy expenditure as estimated by means of the equation of Harris and Benedict (27). At experimental days subjects came to the lab after an overnight fast of at least 10 hours. Body weight (BW) (Seca, Model 861, Hamburg, Germany; accuracy of $0.1 \mathrm{~kg}$ ) was recorded while subjects were in underwear. Subsequently, a Teflon catheter (Baxter BV, Utrecht, The Netherlands) was inserted into an antecubital vein and a resting blood sample was drawn $(t=0)$. Then subjects were offered a breakfast, which they had to consume within $15 \mathrm{~min}$, and 15, 30, 
60, 90, 120 and 180 minutes after the end of consumption of the meal blood samples were taken. Appetite sensations (hunger, satiety, fullness and desire to eat) were measured at the same time points by means of $100 \mathrm{~mm}$ Visual Analogue Scales (mm VAS).

\section{Biochemical analyses}

Blood samples were collected in EDTA containing tubes for glucose, insulin, glucagon, triglyceride (TG) and free fatty acid (FFA) analyses. EDTA blood to which aprotinin (5kIU/ml blood; Sigma-Aldrich Chemie BV, Zwijndrecht, The Netherlands) was added was used for glucagon analysis. Blood samples were centrifuged at $1000 \mathrm{~g}$ at $4^{\circ} \mathrm{C}$ for 10 min. Aliquots of plasma were frozen immediately in liquid nitrogen and stored at $45^{\circ} \mathrm{C}$. Glucose and triglycerides were analyzed by an enzymatic in vitro test on a Roche/Hitachi automated analyzer with Roche reagentia kits (Roche Diagnostics, Basel, Switzerland) and free fatty acids with reagentia kits from Wako (Wako Chemicals, Neuss, Germany). Insulin was analyzed by radioimmunoassay (Human Insulin Specific RIA kit, LINCO Research, Missouri, USA) as was glucagon (Glucagon RIA kit, LINCO Research, Missouri, USA). HOMA index for insulin resistance (HOMAir) was calculated by the following formula: [glucose]*[insuline]/22.5 (28).

\section{Statistical analyses}

All data are presented as means \pm SEM. Total areas under the curve (AUC) of the postprandial responses were calculated. For variables showing clear postprandial responses (insulin, glucagon and glucose), the time-point at which peak concentrations were reached, was used to analyse peak responses. Statistical analysis was performed using SPSS for Mac OS X software (SPSS, Chicago, IL). For most statistical analyses the two protein groups were combined. To analyze the within-group effect of the $a d$ libitum diet on body weight, AUC for glucose, insulin, glucagon, triglycerides (TG), FFA and VAS scores, paired Student's t-tests were done. Furthermore, the within-group differences in fasting $(t=0)$, peak and final concentrations $(t=180)$ at the beginning and the end of the diet intervention were analyzed with paired Student's t-tests. Oneway ANOVA analysis was used to test whether HOMA index, AUCs for each variable and fasting, peak and final concentrations for insulin, glucagon and glucose differed between diet groups. The level of statistical significance was set at $\mathrm{P}<0.05$. 


\section{Results}

\section{Composition of the study diets and anthropometrical measures}

During the VLCD weight loss period groups lost $8.6 \pm 1.3 \mathrm{~kg}, 9.6 \pm 1.1 \mathrm{~kg}$ and $9.8 \pm 1.0$ $\mathrm{kg}$ body weight (means \pm SEM) in respectively the HC, HPC and HPW group (no significant differences among groups). In the weight maintenance period HPC and HPW did not differ in weight change $(-0.35 \pm 1.03 \mathrm{~kg}$ and $-0.59 \pm 1.02 \mathrm{~kg}$, respectively; $\mathrm{p}=0.87$ ). Because there were no statistically significant differences in any of the variables studied between the HPC and the HPW group, these groups were combined for further analyses.

At the end of the intervention period the HC group consumed approximately $63 \mathrm{En} \%$ carbohydrates, $12 \mathrm{En} \%$ proteins and $21 \mathrm{En} \%$ fat while the HP group consumed approximately $35 \mathrm{En} \%$ proteins, $41 \mathrm{En} \%$ carbohydrates and $24 \mathrm{En} \%$ fat. HC and HP groups differed significantly from each other in carbohydrate intake and in protein intake $(\mathrm{p}<0.005)$ but not in fat intake (Chapter 5).

The BW change over the first two weeks after the weight loss phase was $0.25 \pm 0.95 \mathrm{~kg}$ $(\mathrm{p}=0.80)$ in the HC and $-0.17 \pm 0.33 \mathrm{~kg}(\mathrm{p}=0.61)$ in the HP group, indicating that subjects were in energy balance at the time of the first meal test in the second week of the intervention period. BW did not change significantly during the weight maintenance period in either of the groups $(1.27 \pm 1.29 \mathrm{~kg} ; \mathrm{p}=0.370$ for $\mathrm{HC}$ and $-0.49 \pm 0.71 ; \mathrm{p}=$ 0.50, for HP) (Table 6.1).

\section{Postprandial responses}

Total postprandial AUC for insulin was significantly lower in the HP group at the end of the dietary intervention period than at the beginning, but this was not found in the $\mathrm{HC}$ group ( $p=0.016$ and $p=0.400$, respectively) (Table 6.1). In the HP group the peak concentration for insulin (at $\mathrm{t}=30$ ) was significantly lower at the end than at the beginning of the intervention $(\mathrm{p}=0.037)$ (Figure 6.1A). In contrast, in the HC group peak concentrations for insulin tended to be higher at the end than at the beginning of the intervention $(\mathrm{p}=0.098)$. As a result, peak insulin concentrations were significantly higher in the HC than in the HP group at the end of the intervention $(p=0.004)$ (Figure 6.1A). Also total AUC for insulin after the intervention was significantly lower in the HP compared to the HC group ( $p=0.017)$ (Table 6.1).

No significant effect of intervention on postprandial glucagon responses was found for any diet group, resulting in similar total AUCs at the beginning and at the end of the intervention ( $\mathrm{p}=0.407$ and $\mathrm{p}=0.206$ for $\mathrm{HC}$ and HP, respectively) (Table 6.1) and also at $\mathrm{t}=0, \mathrm{t}=30$ and $\mathrm{t}=180$ no significant differences in concentration were found within or between groups (Figure 6.1B). 
Table 6.1 Body weight, HOMA index and total AUC for variables measured before and after weight maintenance after a high-protein meal

\begin{tabular}{|c|c|c|c|c|}
\hline & \multicolumn{2}{|c|}{$\mathrm{HC}(\mathrm{N}=6)$} & \multicolumn{2}{|c|}{$\mathrm{HP}(\mathrm{N}=14)$} \\
\hline & Week 8 & Week 18 & Week 8 & Week 18 \\
\hline Body Weight (kg) & $95.7 \pm 6.1$ & $96.9 \pm 6.0$ & $85.3 \pm 4.1$ & $84.8 \pm 4.4$ \\
\hline $\mathrm{HOMA}_{\mathrm{IR}}$ & $4.8 \pm 1.7$ & $5.8 \pm 2.6$ & $3.1 \pm 0.4$ & $2.9 \pm 1.0$ \\
\hline Glucose $(\mathrm{mM} \bullet 3 \mathrm{~h})$ & $88.3 \pm 40.5$ & $62.6 \pm 35.3$ & $73.7 \pm 33.6$ & $29.8 \pm 27.3$ \\
\hline Insulin $\left(\mathrm{mU} \bullet 3 \mathrm{~h} \bullet \mathrm{L}^{-1}\right)$ & $15497 \pm 4098$ & $13190 \pm 2768$ & $9638.2 \pm 788$ & $7736 \pm 734^{*} \#$ \\
\hline Glucagon $\left(\mathrm{pg} \bullet 3 \mathrm{~h} \bullet \mathrm{mL}^{-1}\right)$ & $5076 \pm 1041$ & $4247 \pm 985$ & $4428 \pm 534$ & $5244 \pm 612$ \\
\hline $\mathrm{TG}(\mathrm{mM} \bullet 3 \mathrm{~h})$ & $1.1 \pm 6.9$ & $9.7 \pm 22.6$ & $15.1 \pm 9.3$ & $28.9 \pm 11.9$ \\
\hline FFA $(\mathrm{mM} \bullet 3 \mathrm{~h})$ & $-56.4 \pm 10.8$ & $-17.3 \pm 13.6$ & $-99.3 \pm 11.4 \#$ & $-65.1 \pm 9.6^{* \#}$ \\
\hline Hunger $(\mathrm{mm} \bullet 3 \mathrm{~h})$ & $-6675 \pm 1369$ & $-6588 \pm 1005$ & $-4844 \pm 1254$ & $-6137 \pm 1826$ \\
\hline Fullness $(\mathrm{mm} \bullet 3 \mathrm{~h})$ & $7804 \pm 1042$ & $7125 \pm 1786$ & $7070 \pm 1005$ & $8922 \pm 1308$ \\
\hline Satiety $(\mathrm{mm} \bullet 3 \mathrm{~h})$ & $6254 \pm 1814$ & $7999 \pm 1582$ & $6277 \pm 1379$ & $8550 \pm 819$ \\
\hline Desire to eat $(\mathrm{mm} \bullet 3 \mathrm{~h})$ & $-8203 \pm 1191$ & $-7979 \pm 1308$ & $-6339 \pm 1326$ & $-6673 \pm 1505$ \\
\hline
\end{tabular}

* Significantly different from week 8 as determined by Paired-samples t-tests $(\mathrm{p}<0.05)$

\# Significantly different from HC group as determined by One-way ANOVA analysis (Significance set at $\mathrm{p}<$ $0.05)$

Total AUC for glucose was similar before and after the intervention in both groups $(\mathrm{p}=$ 0.266 and $\mathrm{p}=0.128$ for $\mathrm{HC}$ and $\mathrm{HP}$ ), but peak concentrations (at $\mathrm{t}=30$ ) were significantly higher at the end than at the beginning of the intervention in the $\mathrm{HC}$ group $(p=0.039)$ (Figure 6.1C).
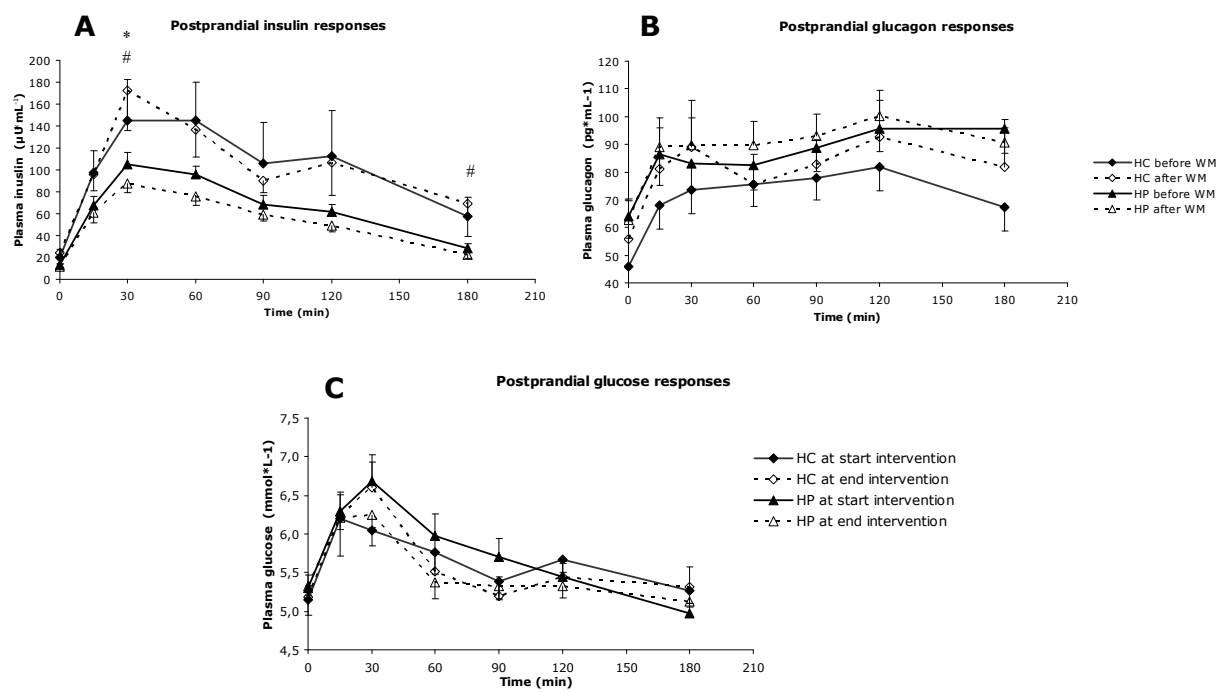

\section{Figure 6.1}

Postprandial at the start and end of the dietary intervention for insulin (A), glucagon (B), glucose (C); *, Significantly different from week 8 for HP group; \#, Significantly different from HC group 
Concerning postprandial AUC of the TG response, no significant differences were found between groups at week 8 and 18 ( $p=0.366$ and $p=0.421$, respectively) or within groups when comparing week 8 with week 18 values $(p=0.641$ and $p=0.194$ for HC and HP, respectively) (Table 6.1). Furthermore, no differences in fasting or peak triglyceride levels were found within or between groups (Figure 6.2A).

At the end of the intervention fasting FFA concentrations were significantly lower than at the beginning in the HP group $(p=0.038)$ but not in the HC group $(p=0.071)$ (Figure 6.2B). The postprandial response (AUC) of FFAs was significantly reduced at the end of the HP intervention $(p=0.039)$ and it was significantly lower than in the HC group $(\mathrm{p}=0.012)($ Table 6.1).

No statistically significant differences in AUCs for subjective hunger and satiety ratings between dietary groups or in changes over time within groups were found (Table 6.1).
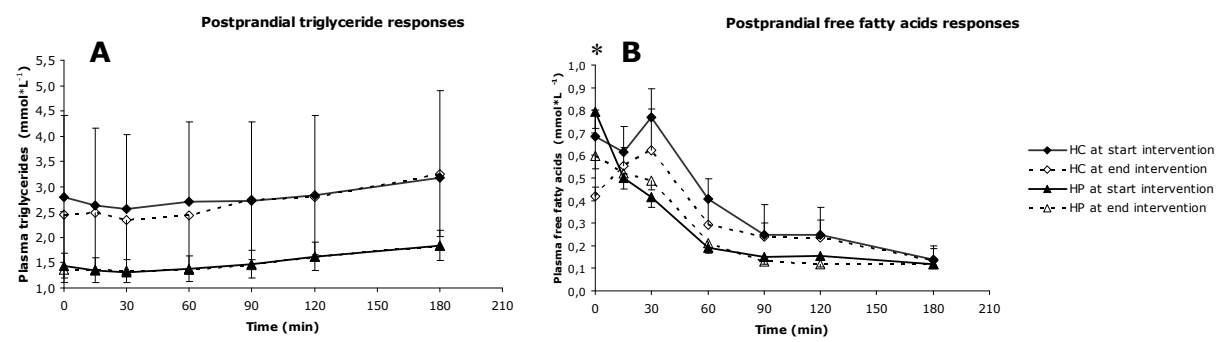

Figure 6.2

Postprandial responses at the start and end of the dietary intervention for triglycerides (A) and free fatty acids (B); *, Significantly different from week 8 for HP group

\section{Discussion}

The present study was undertaken to find out whether habitual high-protein intake results in adaptation of the hormonal and metabolic responses to a high-protein meal. The results of the present study show that the protein-induced postprandial insulin but not glucagon response was reduced after a 10 week high-protein diet, but that this did not affect the postprandial glucose response implying that insulin sensitivity had improved. No changes in overall postprandial insulin, glucagon or glucose responses to a high-protein meal were found on a high-carbohydrate diet, but the peak glucose concentration was significantly increased at the end of the high-carbohydrate diet. The postprandial FFA suppression was less pronounced at the end of the high protein diet than at the beginning. No effect of any diet was found on postprandial TG responses and hunger and satiety ratings.

As table 6.1 shows, BW within and between groups did not change significantly during the intervention period. In the original study with a total of 48 subjects that completed 
the study significant differences in BW changes between groups were found $(1.19 \pm$ $0.90 \mathrm{~kg}$ in the HC and $-1.09 \pm 0.59 \mathrm{~kg}$ in the HP group; $\mathrm{p}=0.04$ ) (Chapter 5). This suggests that the number of subjects participating in this sub-study was too small to detect statistically significant differences.

In the present study we found that habitual consumption of high-protein meals during weight maintenance resulted in reduced postprandial insulin responses. Although this is suggestive for adaptation to the insulin-stimulating effect of proteins, this lower insulin response might also be the result of a change in insulin sensitivity. Although in the larger study the HOMA index, a surrogate marker for insulin sensitivity, tended to have increased more in the HC $(0.62 \pm 0.47)$ than $\mathrm{HP}(0.02 \pm 0.24 ; \mathrm{p}=0.21)$ group, there was no statistically significant decrease in HOMA index on the high-protein diet. Also in this sub-population HOMA index did not change significantly (Table 6.1; $\mathrm{p}=0.121$ ). Since adaptation to high-protein meals on a high protein diet might result in lower insulin secretion, we hypothesised that this would coincide with higher plasma glucose levels when insulin sensitivity was unchanged. The glucose response at the end of the intervention was, though, similar as at the beginning of the intervention, which suggests that insulin sensitivity was improved. This is in line with the beneficial effect of highprotein diets on insulin sensitivity and postprandial glucose control that has been described previously (20-25).

Interestingly, peak concentrations for insulin tended to be higher at the end than at the beginning of the intervention in the HC group $(\mathrm{p}=0.098)$. Dietary protein can stimulate insulin secretion in the absence of carbohydrates $(5,29)$ and, when co-ingested with carbohydrates, substantially increase the carbohydrate-induced insulin response $(17,30$, 31). Therefore, the tendency for the higher insulin response after the intervention in the HC group might be because subjects had relatively low protein intake for 10 weeks, which may have sensitised them to amino acid-induced insulin secretion. Because peak concentrations for glucose were also higher at the end than at the beginning of the high carbohydrate diet intervention, this is suggestive of a decrease in insulin sensitivity on the $\mathrm{HC}$ diet. High-carbohydrate diets have indeed been found to be negatively associated with insulin sensitivity and this mainly for carbohydrate diets with a high glycemic index (32). Although we tried to guide subjects in the high-carbohydrate diet group to consume mainly products high in complex carbohydrates, these are not necessarily low in glycemic index. Furthermore, high-carbohydrate diets can also influence insulin sensitivity indirectly by increasing lipogenesis (33) as reviewed by Chong and colleagues (34).

With respect to blood lipids the postprandial TG response was not affected by any of the diets. It has been shown both in an ad libitum setting and in a design where body weight was kept constant that a HC diet influenced fasting TG concentrations negatively (35, 
36). We reported similar findings in the original study (Chapter 5) but here we show that an ad libitum $\mathrm{HC}$ diet does not affect the postprandial TG response after a high protein meal. The significant difference in postprandial FFA response at the end of the dietary intervention between the HP and $\mathrm{HC}$ diet supports the beneficial effect of the $\mathrm{HP}$ diet on insulin sensitivity and the less positive effect of the $\mathrm{HC}$ diet in this respect.

Finally, we also determined the postprandial hunger and satiety responses by means of visual analogue scales. Since the number of subjects participating in the present study was rather low for analyzing subjective appetite ratings, these results can only give an indication. When looking at differences in postprandial satiety rating before and after weight maintenance, subjective satiety was not significantly influenced by type of diet. The present results do not support the findings of Long and colleagues who reported that the satiating effect of dietary protein varies inversely with habitual protein intake (26), but they are in accordance with the recently published study of Leidy and colleagues (37). In this study, where the effect of acute and chronic consumption of higher dietary protein on, amongst others, appetite, was evaluated, it was demonstrated that satiety was not affected by chronic protein intake.

In conclusion, in the present study habitual consumption of a high-protein diet resulted in a reduced postprandial insulin response without a change in glucose response, suggesting improved insulin sensitivity. Furthermore, the protein-induced insulin response tended to be reduced in the HC group, while peak concentrations for glucose were higher at the end than at the beginning of the intervention period, suggesting a reduced insulin sensitivity. Finally, the results of the present study indicated that the satiety-inducing effect of protein was not markedly influenced by habitual protein intake.

\section{Acknowledgements}

This work was supported by Kerry Bio-Science, Almere, The Netherlands. The authors would like to thank Dr. W. Calame and Dr. A.D. Siemensma from Kerry Bioscience for their contributions and fruitful discussions. 


\section{References}

1. Tremblay, A., Boule, N., Doucet, E. \& Woods, S. C. (2005) Is the insulin resistance syndrome the price to be paid to achieve body weight stability? Int J Obes (Lond) 29: 1295-1298.

2. Woods, S. C., Lutz, T. A., Geary, N. \& Langhans, W. (2006) Pancreatic signals controlling food intake; insulin, glucagon and amylin. Philos Trans R Soc Lond B Biol Sci 361: 1219-1235.

3. Newsholme, P., Brennan, L., Rubi, B. \& Maechler, P. (2005) New insights into amino acid metabolism, beta-cell function and diabetes. Clin Sci (Lond) 108: 185-194.

4. Calbet, J. A. \& MacLean, D. A. (2002) Plasma glucagon and insulin responses depend on the rate of appearance of amino acids after ingestion of different protein solutions in humans. J Nutr 132: 21742182.

5. Kabadi, U. M. (1991) Dose-kinetics of pancreatic alpha- and beta-cell responses to a protein meal in normal subjects. Metabolism 40: 236-240.

6. Michelle Furtado, L., Poon, V. \& Klip, A. (2003) GLUT4 activation: thoughts on possible mechanisms. Acta Physiol Scand 178: 287-296.

7. Jiang, G. \& Zhang, B. B. (2003) Glucagon and regulation of glucose metabolism. Am J Physiol Endocrinol Metab 284: E671-678.

8. Stryer, L. (1997) Biochemistry, 4th ed. W.H. Freeman and Company, New York.

9. Perea, A., Clemente, F., Martinell, J., Villanueva-Penacarrillo, M. L. \& Valverde, I. (1995) Physiological effect of glucagon in human isolated adipocytes. Horm Metab Res 27: 372-375.

10. Carlson, M. G., Snead, W. L. \& Campbell, P. J. (1993) Regulation of free fatty acid metabolism by glucagon. J Clin Endocrinol Metab 77: 11-15.

11. Bertin, E., Arner, P., Bolinder, J. \& Hagstrom-Toft, E. (2001) Action of glucagon and glucagon-like peptide-1-(7-36) amide on lipolysis in human subcutaneous adipose tissue and skeletal muscle in vivo. $\mathrm{J}$ Clin Endocrinol Metab 86: 1229-1234.

12. Gravholt, C. H., Moller, N., Jensen, M. D., Christiansen, J. S. \& Schmitz, O. (2001) Physiological levels of glucagon do not influence lipolysis in abdominal adipose tissue as assessed by microdialysis. J Clin Endocrinol Metab 86: 2085-2089.

13. Hubbard, R., Kosch, C. L., Sanchez, A., Sabate, J., Berk, L. \& Shavlik, G. (1989) Effect of dietary protein on serum insulin and glucagon levels in hyper- and normocholesterolemic men. Atherosclerosis 76: 55-61.

14. Sanchez, A. \& Hubbard, R. W. (1991) Plasma amino acids and the insulin/glucagon ratio as an explanation for the dietary protein modulation of atherosclerosis. Med Hypotheses 36: 27-32.

15. Sugano, M., Ishiwaki, N. \& Nakashima, K. (1984) Dietary protein-dependent modification of serum cholesterol level in rats. Significance of the arginine/lysine ratio. Ann Nutr Metab 28: 192-199.

16. Henkel, E., Menschikowski, M., Koehler, C., Leonhardt, W. \& Hanefeld, M. (2005) Impact of glucagon response on postprandial hyperglycemia in men with impaired glucose tolerance and type 2 diabetes mellitus. Metabolism 54: 1168-1173.

17. Manders, R. J., Wagenmakers, A. J., Koopman, R., Zorenc, A. H., Menheere, P. P., Schaper, N. C., Saris, W. H. \& van Loon, L. J. (2005) Co-ingestion of a protein hydrolysate and amino acid mixture with carbohydrate improves plasma glucose disposal in patients with type 2 diabetes. Am J Clin Nutr 82: 76-83.

18. Manders, R. J., Koopman, R., Sluijsmans, W. E., van den Berg, R., Verbeek, K., Saris, W. H., Wagenmakers, A. J. \& van Loon, L. J. (2006) Co-ingestion of a protein hydrolysate with or without additional leucine effectively reduces postprandial blood glucose excursions in Type 2 diabetic men. $\mathrm{J}$ Nutr 136: 1294-1299. 
19. Nuttall, F. Q., Mooradian, A. D., Gannon, M. C., Billington, C. \& Krezowski, P. (1984) Effect of protein ingestion on the glucose and insulin response to a standardized oral glucose load. Diabetes Care 7: 465-470.

20. Nuttall, F. Q., Gannon, M. C., Saeed, A., Jordan, K. \& Hoover, H. (2003) The metabolic response of subjects with type 2 diabetes to a high-protein, weight-maintenance diet. J Clin Endocrinol Metab 88: 3577-3583.

21. Gannon, M. C., Nuttall, F. Q., Saeed, A., Jordan, K. \& Hoover, H. (2003) An increase in dietary protein improves the blood glucose response in persons with type 2 diabetes. Am J Clin Nutr 78: 734-741.

22. Gannon, M. C. \& Nuttall, F. Q. (2004) Effect of a high-protein, low-carbohydrate diet on blood glucose control in people with type 2 diabetes. Diabetes 53: 2375-2382.

23. Nuttall, F. Q. \& Gannon, M. C. (2004) Metabolic response of people with type 2 diabetes to a high protein diet. Nutr Metab (Lond) 1: 6.

24. Gannon, M. C. \& Nuttall, F. Q. (2006) Control of blood glucose in type 2 diabetes without weight loss by modification of diet composition. Nutr Metab (Lond) 3: 16.

25. Nuttall, F. Q. \& Gannon, M. C. (2006) The metabolic response to a high-protein, low-carbohydrate diet in men with type 2 diabetes mellitus. Metabolism 55: 243-251.

26. Long, S. J., Jeffcoat, A. R. \& Millward, D. J. (2000) Effect of habitual dietary-protein intake on appetite and satiety. Appetite 35: 79-88.

27. Roza, A. M. \& Shizgal, H. M. (1984) The Harris Benedict equation reevaluated: resting energy requirements and the body cell mass. Am J Clin Nutr 40: 168-182.

28. Matthews, D. R., Hosker, J. P., Rudenski, A. S., Naylor, B. A., Treacher, D. F. \& Turner, R. C. (1985) Homeostasis model assessment: insulin resistance and beta-cell function from fasting plasma glucose and insulin concentrations in man. Diabetologia 28: 412-419.

29. Claessens, M., Calame, W., Siemensma, A. D., Saris, W. H. M. \& van Baak, M. A. (2007) The thermogenic and metabolic effect of protein hydrolysate with or without a carbohydrate load in healthy male subjects. Metabolism 56: 1051-1059.

30. Claessens, M., Calame, W., Siemensma, A. D., van Baak, M. A. \& Saris, W. H. M. (2007) The effect of different protein hydrolysate/carbohydrate mixtures on postprandial glucagon and insulin responses in healthy subjects. Eur J Clin Nutr.

31. Spiller, G. A., Jensen, C. D., Pattison, T. S., Chuck, C. S., Whittam, J. H. \& Scala, J. (1987) Effect of protein dose on serum glucose and insulin response to sugars. Am J Clin Nutr 46: 474-480.

32. McKeown, N. M., Meigs, J. B., Liu, S., Saltzman, E., Wilson, P. W. \& Jacques, P. F. (2004) Carbohydrate nutrition, insulin resistance, and the prevalence of the metabolic syndrome in the Framingham Offspring Cohort. Diabetes Care 27: 538-546.

33. Wolever, T. M. (2000) Dietary carbohydrates and insulin action in humans. Br J Nutr 83 Suppl 1: S97102.

34. Chong, M. F., Fielding, B. A. \& Frayn, K. N. (2007) Metabolic interaction of dietary sugars and plasma lipids with a focus on mechanisms and de novo lipogenesis. Proc Nutr Soc 66: 52-59.

35. Appel, L. J., Sacks, F. M., Carey, V. J., Obarzanek, E., Swain, J. F., Miller, E. R., 3rd, Conlin, P. R., Erlinger, T. P., Rosner, B. A. et al. (2005) Effects of protein, monounsaturated fat, and carbohydrate intake on blood pressure and serum lipids: results of the OmniHeart randomized trial. Jama 294: 24552464.

36. Dumesnil, J. G., Turgeon, J., Tremblay, A., Poirier, P., Gilbert, M., Gagnon, L., St-Pierre, S., Garneau, C., Lemieux, I. et al. (2001) Effect of a low-glycaemic index--low-fat--high protein diet on the atherogenic metabolic risk profile of abdominally obese men. Br J Nutr 86: 557-568.

37. Leidy, H. J., Mattes, R. D. \& Campbell, W. W. (2007) Effects of acute and chronic protein intake on metabolism, appetite, and ghrelin during weight loss. Obesity (Silver Spring) 15: 1215-1225. 


\section{Chapter 7}

General discussion 
This thesis focuses on the manipulation of the insulin:glucagon ratio by dietary protein and its role in glycemic control, body weight management and cardiovascular disease. Since these hormones have counter-regulatory functions in substrate metabolism, it might be possible to influence glycemic control, substrate oxidation and lipid metabolism and eventually maybe also body weight, through manipulating the insulin:glucagon ratio. In chapter 1 four research questions were formulated, which we tried to answer by conducting several studies that are described in the subsequent chapters. In this final chapter the findings of these studies in relation to the research questions are discussed and placed in a broader perspective.

\section{Can the insulin and glucagon response and insulin:glucagon ratio be influenced by protein source, protein load and/or structure of the protein?}

\section{Effect of protein source}

Little is known about the effect of different protein sources on insulin and glucagon secretion. Since glucagon is a counter-regulatory hormone of insulin we expected that proteins inducing high insulin responses would induce lower glucagon responses and the other way around. As described in chapter 2 we found that a high amino acidinduced glucagon response does not necessarily go together with a low insulin response, suggesting that amino acid-induced insulin and glucagon responses are independent of each other. In addition, we found that both the insulin and glucagon response were dependent on branched-chain amino acid concentrations. Like others described previously (1-3), we also found that a protein hydrolysate/carbohydrate mixture induced significantly higher insulin responses than a carbohydrate load alone. Also in similarity to the findings of others, we did not find an effect of protein source on the insulin response $(2,3)$. Moreover, glucagon responses seemed to be more affected by protein source than insulin responses. It might well be that if protein hydrolysates were tested without carbohydrate co-ingestion, which would exclude the carbohydrate-induced insulin response, the variation in protein-induced insulin responses would have been more apparent. Therefore, the study described in chapter 3 was done with intact protein/protein hydrolysates without carbohydrate co-ingestion.

\section{Effect of protein load}

When we studied insulin and glucagon responses with increasing protein load, as described in chapter 3 , we found that the glucagon response was more dose-dependent 
than the insulin response, although both insulin and glucagon increased with increasing protein load. This is in line with the findings of Rérat et al (4) but not with studies reported by Spiller et al (1) and Kabadi (5). Spiller and colleagues did not find a dosedependent effect of increasing protein loads with carbohydrate co-ingestion on insulin responses possibly due to the masking effect of the carbohydrate-induced insulin response (1). Kabadi on the other hand, reported that when studying increasing amounts of protein hydrolysate, of which the composition and degree of hydrolysis was not clearly stated, without carbohydrate co-ingestion, insulin was affected more by protein load than glucagon (5). The high protein loads studied (from $0.25 \mathrm{~g} / \mathrm{kg} \mathrm{BW}$ up to $2 \mathrm{~g} / \mathrm{kg}$ BW) might have caused plasma glucagon levels to reach a plateau as also suggested by Kabadi (5). Since we studied protein loads up to $0.6 \mathrm{~g} / \mathrm{kg} \mathrm{BW}$, which resulted in dosedependent glucagon levels, this suggests that glucagon did not reach a plateau in our study. In our study, protein loads of $0.6 \mathrm{~g} / \mathrm{kg} \mathrm{BW}$ were experienced as not tasteful for both protein sources tested (soy and whey) in the intact as well as the hydrolysed structure. Therefore, protein loads of $0.6 \mathrm{~g} / \mathrm{kg} \mathrm{BW}$ or higher might not be suitable for practical implications.

When trying to manipulate the insulin:glucagon ratio by changing the protein load, lower protein loads would be more appropriate to induce a higher insulin:glucagon ratio, while by increasing the protein load mainly glucagon responses will be affected resulting in a lower insulin:glucagon ratio.

\section{Effect of hydrolysation of the protein}

Regarding protein structure, we expected that protein hydrolysates would be taken up faster and therefore induce a faster increase in insulin and glucagon responses than their intact form. We did not find differences in insulin or glucagon responses between intact whey protein (WPI) and whey protein hydrolysate (WPH), while intact soy protein (ISP) induced faster insulin and glucagon responses than soy protein hydrolysate (SPH), which was against our expectations. As discussed in chapter 3, the molecular weight profiles of SPH and WPH were similar showing that in theory similar amounts of diand tri-peptides should have been present in both types of hydrolysates. These small peptides can be taken up and further metabolised into free amino acids by enterocytes. Since the molecular weight profiles for SPH and WPH were similar, we expected to find similar differences between SPI vs SPH and WPI vs WPH. Therefore, these results suggest that soy protein is metabolised in a different way than whey protein. In this regard, it has been reported that the biological value of soy protein is inferior to that of casein (6). The biological value of whey protein has not been studied as extensively as that of soy protein and casein. The protein quality is thought to be dependent on the degree and velocity by which the protein is digested, absorbed as amino acids, and 
retained in the gut as newly synthesised protein (6). Intact soy protein seems to be ingested and absorbed by the splanchnic area rapidly and transported to the liver to be degraded rapidly into urea, resulting in reduced uptake by the peripheral tissues (like skeletal muscle) (6-8). It is possible that consumption of partly hydrolysed soy protein results in an even faster absorption of free amino acids and in an even more reduced uptake by peripheral organs. When amino acids are rapidly removed from circulation, their insulin and glucagon stimulating capacity might be reduced. Although this hypothesis should be studied more carefully, this might explain why for soy protein the intact form induced faster insulin and glucagon responses than its hydrolysed form. We studied 2 fast digestible proteins and their hydrolysates. Casein and its hydrolysed form, the only slow protein described until now due to its slow gastric emptying pattern caused by the curd formation, might be able to induce different hormonal responses.

\section{The effect of protein hydrolysate consumption with a carbohydrate pre- or afterload}

Since in normal life situations, people rarely consume proteins without addition of carbohydrates or fat, the physiological relevance of the insulin and glucagon response induced by pure protein consumption might be small. Since carbohydrates have a strong influence on both the insulin and glucagon response, we were interested in the effect of protein hydrolysate consumption with an equi-energetic carbohydrate pre- or afterload. As described in chapter 4, we found that the insulin response induced by soy protein hydrolysate was similar to that induced by an equi-energetic carbohydrate load. Although SPH most probably induces relatively low insulin responses compared to other protein sources, these findings suggest that proteins alone can induce similar and sometimes probably even higher insulin responses than carbohydrates.

When carbohydrate consumption was preceded by SPH consumption, the already elevated plasma insulin levels, induced by SPH, prevented the increase in plasma glucose normally induced by carbohydrate consumption. In type 2 diabetic subjects coingestion of protein hydrolysate with carbohydrate has been found to induce significantly increased insulin responses when compared to a carbohydrate load alone (9). This together with our results implies that high glycemic index carbohydrates can be consumed without inducing high glucose responses when they are preceded by protein ingestion, although it remains to be investigated whether this is also the case in type 2 diabetic patients.

Regarding glucagon, the most interesting finding was that glucagon responses were not or only slightly influenced by elevated glucose and insulin concentrations. It has been suggested that glucagon secretion is suppressed by postprandial insulin (10). Pipeleers and colleagues hypothesized, though, that amino acid-induced glucagon secretion is not 
or only partly inhibited by increased insulin levels (11). Our findings that protein consumption induces a glucagon response even when plasma insulin levels are increased support this hypothesis. When a carbohydrate load preceded protein hydrolysate consumption the combined carbohydrate- and protein-induced insulin response resulted in plasma glucose levels below baseline. These low glucose concentrations might also have contributed to the glucagon response observed when protein hydrolysate was consumed after the carbohydrate load. If glucagon indeed turns out to be lipolytic or to have other important effects, this finding might be of importance.

Taken together, these findings suggest that insulin and glucagon responses can independently of each other be influenced by mainly branched-chain amino acids. Furthermore, our results imply that it is possible to influence the insulin:glucagon ratio by protein source and protein load by manipulating insulin and glucagon separately. In this regard, our results suggest that glucagon is more affected by protein source and load than insulin. Interestingly, carbohydrate co-ingestion interfered with the effect of protein-induced insulin secretion while it did not affect glucagon secretion drastically.

\section{How can the insulin:glucagon ratio affect energy expenditure and substrate oxidation}

The thermogenic effect of proteins and high-protein meals has been reported previously (12-17). Since glucagon is a hormone that, except during the fasted state, is mainly secreted upon protein consumption but not after carbohydrate consumption, we hypothesised that glucagon might partly be responsible for the thermogenic effect of proteins, while insulin is mainly responsible for the thermogenic effect of carbohydrates. When comparing a single protein hydrolysate load with a single carbohydrate load, we found that the protein-induced glucagon response coincided with a prolonged increase in energy expenditure, as described in chapter 4. Thermogenesis induced by soy protein hydrolysate combined with a carbohydrate load was not influenced by the order of consumption. Furthermore, we found that insulin, rather than glucagon contributed to changes in energy expenditure. Therefore, the similar insulin and glucagon responses induced by soy protein hydrolysate with a carbohydrate pre- or afterload could explain why energy expenditure was also similar in both conditions.

When considering the lipolytic effect that has been attributed to glucagon $(18,19)$ our results did not support this. To study the lipolytic effect of glucagon more closely, we performed a pilot study in which we isolated adipocytes from human fat biopsies and 
exposed them to different glucagon levels ranging from physiological to supraphysiological concentrations. Irrespective to the glucagon concentration used, we did not find any effect of glucagon on lipolysis, as determined by glycerol measurements in the medium, while addition of isoprenaline, a known lipolytic agent, induced a clear lipolytic effect (results not shown). This is in contrast to other in vitro studies reporting a lipolytic effect of glucagon in isolated adipocytes $(18,19)$, but is in line with findings from microdialysis experiments to test the lipolytic effect of glucagon $(20,21)$. Therefore, the thermogenic effect of dietary protein does not seem to be directly related to glucagon-induced lipolysis. Furthermore, our results suggest that the effect of glucagon on gluconeogenesis and ureagenesis, both processes with a relatively high energy cost, are inferior to the insulin-induced effects on protein synthesis since, as described in chapter 4, plasma insulin was more strongly associated with changes in energy expenditure than plasma glucagon. Although carbohydrate consumption stimulates insulin secretion too, protein synthesis will mainly be stimulated when circulating amino acids levels are enhanced (22). Since this effect of protein-induced insulin secretion on energy expenditure is related to increased protein synthesis, which needs time before occurring, this might explain why energy expenditure remained elevated while plasma insulin levels decreased already.

Taken together, our results suggest that mainly the protein-induced insulin and to a lesser extent the protein-induced glucagon response are responsible for the thermogenic effect of dietary protein. There should be, though, factors other than insulin and glucagon, contributing to the thermogenic effect of proteins. Therefore, although the effect might be small, proteins inducing a high insulin:glucagon ratio might increase energy expenditure more than proteins inducing a lower insulin:glucagon ratio.

\section{Is the positive effect of high-protein diets on body weight management related to protein-induced insulin or glucagon secretion?}

High-protein compared to high-carbohydrate diets are found to be more effective in reducing weight loss and maintaining weight stable after a period of weight loss, most probably due to their high satiating and thermogenic effect (23-31). The postprandial insulin and glucagon-stimulating effect of proteins might increase energy expenditure and in this regard be beneficial for weight maintenance. Fasting insulin and glucagon levels, on the other hand, are increased in subjects with impaired glucose tolerance, and while glucagon concentrations remain elevated in type 2 diabetic subjects, insulin levels 
decrease upon developing type 2 diabetes (32-36). Therefore, it would not be beneficial to have increased fasting insulin and glucagon levels. As described in chapter 5 longterm consumption of high-protein diets did not influence fasting insulin or glucagon levels during weight maintenance, which both remained significantly lower than before weight loss. Postprandial tests showed that although insulin responses were reduced, postprandial glucose responses were not affected, which implies that insulin sensitivity was not reduced and might even have been improved. Also postprandial glucagon responses were not affected by weight maintenance while consuming a high-protein diet. In the high-carbohydrate group, on the other hand, fasting insulin tended to be higher and fasting glucagon was significantly higher after weight maintenance. Postprandial insulin and glucagon responses were not affected in the high-carbohydrate group, while postprandial peak concentrations for glucose were higher after weight maintenance compared to before, which suggests reduced insulin sensitivity.

Next to differences in insulin responses, the study also revealed that the high-protein diet was better regarding weight management than the high-carbohydrate diet. Since we did not find differences in postprandial glucagon responses in any of the studied groups, we do not expect glucagon metabolism to be responsible for the differences in body weight between both groups. Even if glucagon is capable somehow to increase energy expenditure, the lack of differences between the high-protein and high-carbohydrate group indicates that in the present study glucagon did not substantially contribute to differences in body weight. Regarding differences in insulin responses, the only clear difference we found was that after weight maintenance the insulin response in the highprotein group was reduced compared to before weight maintenance. Since one of the effects of insulin is to increase protein synthesis, which has a high energetic cost, this change in insulin response would suggest that changes in insulin also would not be responsible for the differences in body weight we found. On the other hand, if liver and skeletal muscle cells have become more insulin sensitive, as suggested by our results, this could imply that not only glucose uptake improved but also that processes involving amino acids uptake and protein synthesis improved and became more insulin sensitive. Although this could mean that insulin-induced protein synthesis is not impaired after weight maintenance, it does not imply that insulin-induced protein synthesis had improved. Therefore, changes in insulin-induced protein synthesis were most probably not responsible for the changes in body weight we observed. Next to insulin-induced protein synthesis, amino acids are found to be capable to stimulate protein synthesis in skeletal muscle and liver by a mechanism independent of the PI 3kinase/PKB pathway, although elevated insulin levels seem to be necessary for amino acids to effectively stimulate protein synthesis (37). Although this could explain part of the difference in body weight between both groups, other processes might be involved. 
From these findings we conclude that the positive effect of high-protein diets on body weight management is not associated with the glucagon-stimulating effect of proteins and could slightly be associated with their insulin-simulating effect, although insulin most probably acts via secondary effects.

\section{Is the positive effect of high-protein diets on risk factors for cardiovascular disease associated with changes in insulin or glucagon secretion?}

Energy-restricted diets in which part of the carbohydrates are replaced by protein, have been found to be associated with improved fasting triglyceride levels $(38,39)$. Also in our study basal triglyceride concentrations were lower in the high-protein group compared to the high-carbohydrate group after weight maintenance. Furthermore, although total cholesterol, HDL and LDL concentrations had increased in both diet groups, fasting levels after weight maintenance remained lower than before weight loss in the high-protein group. Also HDL cholesterol tended to have increased more during weight maintenance in the high-protein compared to high-carbohydrate group. Both insulin and glucagon are thought to be associated with cardiovascular disease (CVD), where insulin is positively associated with triglycerides, total and LDL cholesterol but negatively associated with HDL cholesterol (40-42). Glucagon, on the other hand, has been found to reduce total and LDL cholesterol (40-42). In similarity to the findings of Layman and colleagues (39) we found that only fasting triglycerides had changed differently between groups during weight maintenance while total cholesterol levels changed in a similar way. HDL cholesterol tended to have increased more in the highprotein group this effect only seemed to be present in the casein-supplemented but not in the whey-supplemented group. In accordance to this, the LDL:HDL ratio decreased only in the HPC vs HC group. When analyzing how much changes in insulin and/or glucagon contributed to changes in the LDL:HDL ratio (results not shown), we found that neither insulin nor glucagon contributed significantly to changes in the LDL:HDL ratio and explained only $5 \%$ of variation when both were included in the model. Also regarding changes in blood pressure, we found that the reduced blood pressure, both systolic and diastolic blood pressure, resulting from weight loss, was maintained in the high-protein group but not in the high-carbohydrate group, although this did not result in significant differences between the groups. Regression analysis revealed that changes in blood pressure (both systolic and diastolic) were not related to changes in insulin or glucagon levels. We did expect a reduced blood pressure in subjects on the high-protein diets due to the known blood pressure-lowering effect of dairy proteins $(43,44)$, which 
were consumed more in the high-protein group (both in the normal diet and as supplements). The lack of a statistically significant effect of our HP diets on blood pressure may be due to the fact that blood pressure was already significantly reduced by the weight loss when the randomized intervention started and the relatively small size of the study.

Taken together, the beneficial effect of high-protein diets on risk factors for cardiovascular disease is not associated with plasma glucagon levels. Mainly the slightly reduced fasting insulin concentrations seemed to be responsible for the reduced triglyceride and increased HDL levels in the HP group. Finally, in our study the HP diets did not reduce blood pressure as we expected, which might be due to our study design.

\section{Final conclusions of the thesis}

From the work described and discussed in the present thesis it can be concluded that mainly glucagon can be influenced by protein source and load and that the effect of protein source and load on insulin might be disturbed by carbohydrate co-ingestion. Nevertheless, glucagon was found to be only weakly associated with energy expenditure and was not involved in the beneficial effect of high-protein diets on weight management and risk factors for cardiovascular disease. Insulin, on the other hand, could explain part of the beneficial effect of high-protein diets on body weight management via its effect on energy expenditure. Finally, although the HP diets, and mainly the casein-supplemented diet, had beneficial effects on HDL cholesterol and the LDL:HDL ratio, this effect was not the result of differences in plasma insulin or glucagon concentrations. 


\section{References}

1. Spiller, G. A., Jensen, C. D., Pattison, T. S., Chuck, C. S., Whittam, J. H. \& Scala, J. (1987) Effect of protein dose on serum glucose and insulin response to sugars. Am J Clin Nutr 46: 474-480.

2. Calbet, J. A. \& MacLean, D. A. (2002) Plasma glucagon and insulin responses depend on the rate of appearance of amino acids after ingestion of different protein solutions in humans. J Nutr 132: 21742182.

3. van Loon, L. J., Saris, W. H., Verhagen, H. \& Wagenmakers, A. J. (2000) Plasma insulin responses after ingestion of different amino acid or protein mixtures with carbohydrate. Am J Clin Nutr 72: 96-105.

4. Rerat, A., Nunes, C. S., Mendy, F. \& Roger, L. (1988) Amino acid absorption and production of pancreatic hormones in non-anaesthetized pigs after duodenal infusions of a milk enzymic hydrolysate or of free amino acids. Br J Nutr 60: 121-136.

5. Kabadi, U. M. (1991) Dose-kinetics of pancreatic alpha- and beta-cell responses to a protein meal in normal subjects. Metabolism 40: 236-240.

6. Luiking, Y. C., Deutz, N. E., Jakel, M. \& Soeters, P. B. (2005) Casein and soy protein meals differentially affect whole-body and splanchnic protein metabolism in healthy humans. J Nutr 135: 1080-1087.

7. Bos, C., Metges, C. C., Gaudichon, C., Petzke, K. J., Pueyo, M. E., Morens, C., Everwand, J., Benamouzig, R. \& Tome, D. (2003) Postprandial kinetics of dietary amino acids are the main determinant of their metabolism after soy or milk protein ingestion in humans. J Nutr 133: 1308-1315.

8. Fouillet, H., Mariotti, F., Gaudichon, C., Bos, C. \& Tome, D. (2002) Peripheral and splanchnic metabolism of dietary nitrogen are differently affected by the protein source in humans as assessed by compartmental modeling. J Nutr 132: 125-133.

9. Manders, R. J., Wagenmakers, A. J., Koopman, R., Zorenc, A. H., Menheere, P. P., Schaper, N. C., Saris, W. H. \& van Loon, L. J. (2005) Co-ingestion of a protein hydrolysate and amino acid mixture with carbohydrate improves plasma glucose disposal in patients with type 2 diabetes. Am J Clin Nutr 82: 76-83.

10. Meier, J. J., Kjems, L. L., Veldhuis, J. D., Lefebvre, P. \& Butler, P. C. (2006) Postprandial suppression of glucagon secretion depends on intact pulsatile insulin secretion: further evidence for the intraislet insulin hypothesis. Diabetes 55: 1051-1056.

11. Pipeleers, D. G., Schuit, F. C., Van Schravendijk, C. F. \& Van de Winkel, M. (1985) Interplay of nutrients and hormones in the regulation of glucagon release. Endocrinology 117: 817-823.

12. Johnston, C. S., Day, C. S. \& Swan, P. D. (2002) Postprandial thermogenesis is increased $100 \%$ on a high-protein, low-fat diet versus a high-carbohydrate, low-fat diet in healthy, young women. J Am Coll Nutr 21: 55-61.

13. Robinson, S. M., Jaccard, C., Persaud, C., Jackson, A. A., Jequier, E. \& Schutz, Y. (1990) Protein turnover and thermogenesis in response to high-protein and high-carbohydrate feeding in men. Am $\mathrm{J}$ Clin Nutr 52: 72-80.

14. Nair, K. S., Halliday, D. \& Garrow, J. S. (1983) Thermic response to isoenergetic protein, carbohydrate or fat meals in lean and obese subjects. Clin Sci (Lond) 65: 307-312.

15. Karst, H., Steiniger, J., Noack, R. \& Steglich, H. D. (1984) Diet-induced thermogenesis in man: thermic effects of single proteins, carbohydrates and fats depending on their energy amount. Ann Nutr Metab 28: 245-252.

16. Swaminathan, R., King, R. F., Holmfield, J., Siwek, R. A., Baker, M. \& Wales, J. K. (1985) Thermic effect of feeding carbohydrate, fat, protein and mixed meal in lean and obese subjects. Am J Clin Nutr 42: $177-181$. 
17. Crovetti, R., Porrini, M., Santangelo, A. \& Testolin, G. (1998) The influence of thermic effect of food on satiety. Eur J Clin Nutr 52: 482-488.

18. Perea, A., Clemente, F., Martinell, J., Villanueva-Penacarrillo, M. L. \& Valverde, I. (1995) Physiological effect of glucagon in human isolated adipocytes. Horm Metab Res 27: 372-375.

19. Carlson, M. G., Snead, W. L. \& Campbell, P. J. (1993) Regulation of free fatty acid metabolism by glucagon. J Clin Endocrinol Metab 77: 11-15.

20. Bertin, E., Arner, P., Bolinder, J. \& Hagstrom-Toft, E. (2001) Action of glucagon and glucagon-like peptide-1-(7-36) amide on lipolysis in human subcutaneous adipose tissue and skeletal muscle in vivo. J Clin Endocrinol Metab 86: 1229-1234.

21. Gravholt, C. H., Moller, N., Jensen, M. D., Christiansen, J. S. \& Schmitz, O. (2001) Physiological levels of glucagon do not influence lipolysis in abdominal adipose tissue as assessed by microdialysis. J Clin Endocrinol Metab 86: 2085-2089.

22. Giordano, M. \& Castellino, P. (1997) Correlation between amino acid induced changes in energy expenditure and protein metabolism in humans. Nutrition 13: 309-312.

23. Skov, A. R., Toubro, S., Ronn, B., Holm, L. \& Astrup, A. (1999) Randomized trial on protein vs carbohydrate in ad libitum fat reduced diet for the treatment of obesity. Int J Obes Relat Metab Disord 23: 528-536.

24. Due, A., Toubro, S., Skov, A. R. \& Astrup, A. (2004) Effect of normal-fat diets, either medium or high in protein, on body weight in overweight subjects: a randomised 1-year trial. Int J Obes Relat Metab Disord 28: 1283-1290.

25. Westerterp-Plantenga, M. S. (2003) The significance of protein in food intake and body weight regulation. Curr Opin Clin Nutr Metab Care 6: 635-638.

26. Westerterp-Plantenga, M. S., Lejeune, M. P., Nijs, I., van Ooijen, M. \& Kovacs, E. M. (2004) High protein intake sustains weight maintenance after body weight loss in humans. Int J Obes Relat Metab Disord 28: 57-64.

27. Lejeune, M. P., Kovacs, E. M. \& Westerterp-Plantenga, M. S. (2005) Additional protein intake limits weight regain after weight loss in humans. Br J Nutr 93: 281-289.

28. Lejeune, M. P., Westerterp, K. R., Adam, T. C., Luscombe-Marsh, N. D. \& Westerterp-Plantenga, M. S. (2006) Ghrelin and glucagon-like peptide 1 concentrations, 24-h satiety, and energy and substrate metabolism during a high-protein diet and measured in a respiration chamber. Am J Clin Nutr 83: 89-94.

29. Weigle, D. S., Breen, P. A., Matthys, C. C., Callahan, H. S., Meeuws, K. E., Burden, V. R. \& Purnell, J. Q. (2005) A high-protein diet induces sustained reductions in appetite, ad libitum caloric intake, and body weight despite compensatory changes in diurnal plasma leptin and ghrelin concentrations. Am J Clin Nutr 82: 41-48.

30. Westerterp, K. R., Wilson, S. A. \& Rolland, V. (1999) Diet induced thermogenesis measured over $24 \mathrm{~h}$ in a respiration chamber: effect of diet composition. Int J Obes Relat Metab Disord 23: 287-292.

31. Westerterp-Plantenga, M. S., Rolland, V., Wilson, S. A. \& Westerterp, K. R. (1999) Satiety related to 24 $\mathrm{h}$ diet-induced thermogenesis during high protein/carbohydrate vs high fat diets measured in a respiration chamber. Eur J Clin Nutr 53: 495-502.

32. Henkel, E., Menschikowski, M., Koehler, C., Leonhardt, W. \& Hanefeld, M. (2005) Impact of glucagon response on postprandial hyperglycemia in men with impaired glucose tolerance and type 2 diabetes mellitus. Metabolism 54: 1168-1173.

33. Jiang, G. \& Zhang, B. B. (2003) Glucagon and regulation of glucose metabolism. Am J Physiol Endocrinol Metab 284: E671-678.

34. Shah, P., Basu, A., Basu, R. \& Rizza, R. (1999) Impact of lack of suppression of glucagon on glucose tolerance in humans. Am J Physiol 277: E283-290. 


\section{Chapter 7}

35. Fanelli, C. G., Porcellati, F., Rossetti, P. \& Bolli, G. B. (2006) Glucagon: the effects of its excess and deficiency on insulin action. Nutr Metab Cardiovasc Dis 16 Suppl 1: S28-34.

36. Ahren, B. (2006) Glucagon secretion in relation to insulin sensitivity in healthy subjects. Diabetologia 49: 117-122.

37. Suryawan, A., O'Connor, P. M., Kimball, S. R., Bush, J. A., Nguyen, H. V., Jefferson, L. S. \& Davis, T. A. (2004) Amino acids do not alter the insulin-induced activation of the insulin signaling pathway in neonatal pigs. J Nutr 134: 24-30.

38. Farnsworth, E., Luscombe, N. D., Noakes, M., Wittert, G., Argyiou, E. \& Clifton, P. M. (2003) Effect of a high-protein, energy-restricted diet on body composition, glycemic control, and lipid concentrations in overweight and obese hyperinsulinemic men and women. Am J Clin Nutr 78: 31-39.

39. Layman, D. K., Boileau, R. A., Erickson, D. J., Painter, J. E., Shiue, H., Sather, C. \& Christou, D. D. (2003) A reduced ratio of dietary carbohydrate to protein improves body composition and blood lipid profiles during weight loss in adult women. J Nutr 133: 411-417.

40. McCarty, M. F. (1999) Vegan proteins may reduce risk of cancer, obesity, and cardiovascular disease by promoting increased glucagon activity. Med Hypotheses 53: 459-485.

41. Hubbard, R., Kosch, C. L., Sanchez, A., Sabate, J., Berk, L. \& Shavlik, G. (1989) Effect of dietary protein on serum insulin and glucagon levels in hyper- and normocholesterolemic men. Atherosclerosis 76: 55-61.

42. Sanchez, A. \& Hubbard, R. W. (1991) Plasma amino acids and the insulin/glucagon ratio as an explanation for the dietary protein modulation of atherosclerosis. Med Hypotheses 36: 27-32.

43. Myers, V. H. \& Champagne, C. M. (2007) Nutritional effects on blood pressure. Curr Opin Lipidol 18: $20-24$.

44. Jauhiainen, T. \& Korpela, R. (2007) Milk peptides and blood pressure. J Nutr 137: 825S-829S. 
Summary 
Dietary proteins are known to induce the secretion of both insulin and glucagon, which have counterregulatory functions in glucose metabolism. The balance between the insulin and glucagon response is important for the regulation of postprandial substrate oxidation and also plays a role in cholesterol metabolism. Recently, energy-restricted as well as high-protein diets as such are found to improve insulin sensitivity, lipid profiles and body weight management. Whether these beneficial effects of high-protein diets can be (partly) attributed to the insulin- and/or glucagon-stimulating effect of dietary proteins is unknown.

In the present thesis four human intervention studies are described. Of these studies three were conducted to investigate whether the insulin and glucagon responses and insulin:glucagon ratio can be influenced by protein source, protein load and/or hydrolysis of the protein and to find out if the insulin:glucagon ratio affects energy expenditure and substrate oxidation.

These studies revealed that a high amino acid-induced glucagon response does not necessarily go together with a low insulin response. This suggests that, unlike the counterregulatory actions of insulin and glucagon in glucose metabolism, amino acidinduced glucagon secretion is not suppressed substantially by amino acid-induced insulin secretion. In this regard, glucagon responses were more affected by protein source and protein load than insulin responses. Therefore, when trying to manipulate the insulin:glucagon ratio by changing the protein load, lower protein loads would be more appropriate to induce a higher insulin:glucagon ratio, while by increasing the protein load mainly glucagon responses will be affected resulting in a lower insulin:glucagon ratio. Regarding the effect of proteins on energy expenditure, we found that insulin, rather than glucagon was associated with changes in energy expenditure. Thus, the thermogenic effect of dietary protein seems to be related more to insulin than to glucagon responses. The effect of protein hydrolysation on postprandial insulin and glucagon responses was rather small when compared two fast digestible proteins and their hydrolysates (whey and soy protein). This selection could have influenced the outcome compared to slow digestible proteins such as casein. When looking at the effect of soy protein hydrolysate consumption with a carbohydrate pre- or afterload, we found that when carbohydrate consumption was preceded by soy protein hydrolysate consumption, the already elevated plasma insulin levels, induced by soy protein hydrolysate, prevented the increase in plasma glucose normally induced by carbohydrate consumption. This observation could have a positive health impact on the use of high glycemic products or meals.

The fourth study investigated whether the effect of high-protein diets on body weight management is related to protein-induced insulin or glucagon secretion and if the effect of high-protein diets on risk factors for cardiovascular disease is associated with 
changes in insulin or glucagon secretion. In this study we compared the effects of a 12week maltodextrin-enriched high-carbohydrate ad libitum diet with those of a highprotein ad libitum diet, enriched with either casein or whey, on body weight, energy intake, blood pressure and parameters of glucose and lipid metabolism in healthy overweight and obese subjects after a period of weight loss induced by an energyrestricted diet. In addition, a subgroup of subjects from each dietary intervention group was also challenged with a high-protein breakfast at the start and at the end of the intervention period to study postprandial responses. This study showed that a substantial increase in dietary protein contributed to better weight management in terms of preventing weight regain after weight loss and in particular by preserving fat free mass. Although in the high-protein casein but not in the high-protein whey group the change in body weight was significantly different from the high-carbohydrate diet group, subjects in the high-protein whey group had lost significantly more body fat mass than subjects in the high-carbohydrate diet group, while no significant change in body fat mass was found when comparing the high-protein casein and high-carbohydrate diet group. Long-term consumption of high-protein diets did not influence fasting insulin or glucagon levels during weight maintenance, which both remained significantly lower than before weight loss. In the high-protein group postprandial insulin responses at the end of the intervention were reduced compared to the start, but postprandial glucose responses were not significantly affected. This is suggestive for improved insulin sensitivity on the high-protein diet. Postprandial glucagon responses were not affected by the intervention in the high-protein diet group. In the high-carbohydrate diet group fasting insulin tended to be higher and fasting glucagon was significantly higher after weight maintenance. When challenged with a high-protein meal, peak concentrations for insulin tended to be higher and peak concentrations for glucose were higher at the end compared to the beginning of the high-carbohydrate diet intervention. This is suggestive of a decrease in insulin sensitivity on the high-carbohydrate diet.

Although the high-protein diets, and mainly the casein-supplemented diet, had beneficial effects on HDL cholesterol and the LDL:HDL ratio, this effect was not associated with differences in plasma insulin or glucagon concentrations. With respect to blood lipids the high-carbohydrate diet induced significantly higher increase in fasting triglyceride concentrations than the high-protein diet, although the postprandial triglyceride response was not affected by any of the diets. Postprandial free fatty acid levels were significantly less suppressed by a high-protein meal at the end of the intervention period in the high-carbohydrate compared to the high-protein group. This difference supports the beneficial effect of the high-protein diet on insulin sensitivity and the less positive effect of the high-carbohydrate diet in this respect. Blood pressure 
tended to be lower on the high-protein diet than on the high-carbohydrate diet, but changes did not reach statistical significance.

The general conclusions of the present thesis are that the insulin:glucagon ratio can be manipulated, mainly, by influencing glucagon secretion. Furthermore, we did not find evidence for an important role of protein-induced glucagon secretion in the beneficial effects of high-protein diets on body weight management and obesity-related risk factors. 
Samenvatting 
Het is bekend dat consumptie van voedingseiwitten leidt tot de verhoging van zowel insuline als glucagon in het bloed, twee hormonen met tegengestelde functies wat betreft glucosehuishouding. Het evenwicht tussen deze hormonen is van belang bij de regulatie van het gebruik van macronutriënten en het cholesterolmetabolisme. Het is aangetoond dat energiebeperkte hoog-eiwit diëten, alsook gewone hoog-eiwitdiëten, een positief effect hebben op de insulinegevoeligheid, samenstelling van bloedlipiden en gewichtscontrole. Of deze positieve effecten van hoog-eiwitdiëten toegeschreven kunnen worden aan het insuline- en/of glucagonstimulerende effect van voedingseiwitten is niet bekend.

In dit proefschrift worden vier humane interventiestudies beschreven. Drie van deze studies werden uitgevoerd om te achterhalen of de insuline en glucagonveranderingen in het plasma en de verhouding tussen beide hormonen beïnvloed kunnen worden door de eiwitbron, de hoeveelheid eiwitten en/of de mate van hydrolyse van eiwitten. Tevens werd bestudeerd of de verhouding tussen insuline en glucagon het energiegebruik en de keuze van macronutriënten als energiesubstraat kan beïnvloeden.

Uit deze studies bleek dat eiwitten die leiden tot relatief hoge glucagonconcentraties niet noodzakelijk gepaard gaan met relatief lage insulineconcentraties. Dit suggereert dat ondanks de tegengestelde functies van insuline en glucagon wat betreft de glucosehuishouding, de glucagonniveaus in het plasma na eiwitconsumptie niet substantiëel onderdrukt worden door de insulineuitscheiding na eiwitconsumptie. Tevens konden we aantonen dat de glucagonconcentratie meer beïnvloed wordt door de eiwitbron en hoeveelheid eiwitconsumptie dan door de verandering in insulineniveau. Hieruit volgt dat wanneer men de verhouding tussen beide hormonen wil beïnvloeden via manipulatie van de hoeveelheid eiwitten, een lagere eiwitinname zou leiden tot een hogere insuline:glucagon verhouding terwijl een grotere eiwitinname zou leiden tot een lagere verhouding tussen insuline en glucagon. Wat betreft het effect van voedingseiwitten op energiegebruik, wezen onze studies uit dat insuline meer samenhangt met energiegebruik dan glucagon. Dit lijkt erop te wijzen dat het stimulerende effect van voedingseiwitten op energiegebruik meer samenhangt met insuline- dan met glucagonveranderingen in het bloed. Bij het bestuderen van het effect van mate van hydrolyse op insuline- en glucagonproductie, konden we slechts kleine verschillen aantonen. Voor deze studie werden twee snel resorbeerbare eiwitten (weien soja-eiwit) gebruikt. Mogelijk zouden de verschillen in insuline- en glucagonconcentraties na consumptie van intacte en gedeeltelijk gehydrolyseerde eiwitten groter geweest zijn, indien we een traag-verteerbaar eiwit in de studie hadden meegenomen. Wanneer de consumptie van gehydrolyseerd soja-eiwit gevolgd werd door koolhydraatinname, zorgde de reeds verhoogde insulineconcentraties, gestimuleerd door eiwitconsumptie, ervoor dat de stijging in bloedglucoseconcentratie die normaal 
waargenomen wordt na koolhydraatconsumptie, uitbleef. Deze waarneming zou toegepast kunnen worden in die situaties waarbij koolhydraatrijke voedingsproducten, die resulteren in hoge glucosespiegels, zoals frisdranken, worden genuttigd om zodoende deze negatieve effecten tegen te gaan.

De vierde studie onderzocht of het positieve effect van hoog-eiwitdiëten op gewichtsbehoud gerelateerd is aan de insuline- en glucagonstimulerende werking van eiwitten en of het positieve effect van hoog-eiwitdiëten op risicofactoren voor hart- en vaatziekten in verband staat met veranderingen in insuline- en glucagonproductie. In deze studie werd het effect van een hoog-koolhydraatdieet via een verrijking met maltodextrine vergeleken met het effect van hoog-eiwitdiëten verrijkt via caseïne- of weisupplementen op gewichtsregulatie, bloeddruk en parameters voor glucose en vethuishouding. Hiervoor werden proefpersonen met overgewicht bestudeerd die, na een gewichtsverlies van ca 5\% lichaamsgewicht, gedurende 12 weken naast hun voeding extra koolhydraat- of eiwitsupplementen dienden te eten. Tevens werd in een subgroep, naar evenredigheid geselecteerd uit de interventiegroepen, het acute effect van een hoog-eiwitmaaltijd op postprandiale responsen getest. Uit deze studie bleek dat het verrijken van de voeding met een aanzienlijke hoeveelheid eiwitten (in totaal \pm 35 En\%) bijdraagt tot een betere controle van het lichaamsgewicht door gewichtstoename na gewichtsverlies te voorkomen en dit met name door het verlies van extra vetmassa en behoud van vetvrije massa. Hoewel de verandering in lichaamsgewicht in de caseïneverrijkte maar niet in de wei-verrijkte hoog-eiwitgroep significant verschilde met de hoog-koolhydraatgroep, hadden de proefpersonen in de wei-verrijkte hoog-eiwitgroep in vergelijking met proefpersonen in de hoog-koolhydraatgroep significant meer lichaamsvet verloren dan proefpersonen in de caseïne-verrijkte hoog-eiwitgroep. Tijdens de gewichtsbehoudperiode had consumpie van een hoog-eiwitdieet geen effect op nuchtere insuline- en glucagonconcentraties in het bloed, hoewel de concentraties op het einde van de interventie nog steeds beduidend lager waren dan voor de gewichtsreductieperiode. In de hoog-eiwit groep was de insulinerespons na een acute hoog-eiwitmaaltijd op het einde van de interventie lager dan aan het begin van de interventie, terwijl de glucoserespons, die gelijktijdig gemeten werd, onveranderd was. Mogelijkerwijs duidt dit op een verbeterde insulinegevoeligheid na de hoog-eiwit interventieperiode. Ook de glucagonresponsen waren gelijkaardig bij het begin en op het einde van de hoog-eiwit interventieperiode. In de hoog-koolhydraat groep, echter, was er een tendens voor hogere nuchtere insulineconcentraties en waren de gevaste glucagonconcentraties beduidend hoger op het eind in vergelijking met het begin van de interventie. Ook na de acute hoog-eiwitmaaltijd was er een tendens voor hogere piekconcentraties voor insuline en waren de piekconcentraties voor glucose significant hoger wanneer deze getest werden op het einde van de interventieperiode en vergeleken 
met de responsen van het begin van de hoog-koolhydraatinterventie. Dit duidt op een mogelijk verlaagde insulinegevoeligheid na het hoog-koolhydraatdieet.

Hoewel beide hoog-eiwitdiëten, en met name het caseïne-verrijkte hoog-eiwitdieet, het goede cholesterol (HDL cholesterol) en de verhouding tussen goede en slechte cholesterol (LDL:HDL verhouding) positief beïnvloedde, was dit effect niet gerelateerd aan veranderingen in insuline- of glucagonconcentraties. Wat betreft bloedlipiden, leidde het hoog-koolhydraatdieet tot hogere nuchtere triglyceride waarden in vergelijking met het hoog-eiwitdieet, hoewel de triglyceriderespons na de acute hoogeiwitmaaltijd door geen van de diëten beïnvloed werd. De vrije vetzuurrespons na de acute hoog-eiwit maaltijd werd na de interventie beduidend minder onderdrukt in de hoog-koolhydraat- dan de hoog-eiwitgroep. Ook dit doet vermoeden dat het hoogeiwitdieet een positief effect heeft op insulinegevoeligheid hetgeen niet gevonden werd voor het hoog-koolhydraatdieet. Tot slot leek de bloeddruk op het einde van de interventie lager te zijn in de hoog-eiwit- dan in de hoog-koolhydraatgroep, hoewel deze verschillen niet statistisch significant waren.

Op basis van de resultaten van dit proefschrift kan geconcludeerd worden dat ten gevolge van inname van eiwit de verhouding tussen insuline- en glucagonconcentraties in het plasma kan worden veranderd, met name door veranderingen in de glucagonspiegels. Echter, we konden niet aantonen dat de eiwit-geïnduceerde glucagonproductie een substantiele bijdrage levert aan het positieve effect van een hoog-eiwitdieet op het gewichtsbehoud na een periode van gewichtsverlies en de aan overgewicht-gerelateerde risicofactoren. 


\section{Dankwoord}


"Zonder proefpersonen geen proefschrift", daarom zou ik als eerste alle proefpersonen die aan mijn studies hebben deelgenomen, willen bedanken. Ook zou ik de bakker van dienst (ons ma) die vele proefpersonen met haar bakkunsten wist te overhalen om ook aan een volgende studie weer deel te nemen, van harte willen danken! Want, hoewel de eiwitdrankjes naar Nederlandse normen 'goed te pruimen' waren, leken de meeste mensen voornamelijk de kleine traktaties na een experimentele dag te prefereren.

Ook dank aan mijn promotors en begeleiders Wim Saris en Marleen van Baak voor het mogelijk maken van dit proefschrift. Wim, jouw vertrouwen heeft me de mogelijkheid gegeven om mezelf volledig te ontplooien en mijn capaciteiten te ontdekken en zelfstandigheid te ontwikkelen. Marleen, mijn oprechte dank voor het inspringen als extra begeleider en promotor! Het is voor ons beiden moeilijk geweest, maar ik ben er zeker van dat je op- en aanmerkingen, en dat waren er wel wat, mijn stukken alleen maar ten goede zijn gekomen.

De beoordelingscommissie (Prof. R. Mensink, Prof. R-J. Brummer, Dr. H. Hendriks, Dr. L. van Loon en Prof. D. Tomé) wil ik bedanken voor het kritisch doornemen en evalueren van mijn proefschrift.

Uiteraard zou er zonder geld en eiwitpreparaten ook geen proefschrift geweest zijn, daarom ook dank aan Kerry Bio-science en in het bijzonder aan Wim Calame (de andere Wim) en André Siemensma. Wim, ook al heb je me vaak achter de veren gezeten en me tot vervelens toe proberen in te laten zien dat éénoog wel degelijk koning is in het land der blinden (en ik vermoed dat ik tot de blinden behoorde) stond je altijd klaar om me de juiste richting uit te sturen wanneer ik dat nodig had. André, het is steeds aangenaam samenwerken geweest met jou.

Wat is een vakgroep zonder secretariaat? Daarom mijn dank aan Larisa, Claudia, Ilona en ook de nieuwe secretaressen Kerstin en Desiree voor alles wat jullie in die 4 jaar voor mij gedaan hebben. Natuurlijk ook dank aan alle andere collega's van HB voor de fijne tijd die we samen beleefd hebben. En in het bijzonder aan Kirsten en Kaatje voor alle steun door dik en dun en tanuurlijk roov de leve fokkietjes die we masen degronken nebbeh! Wat had ik zonder jullie gemoeten? Lydia, ik ben mijn AiO periode als jouw kamergenote begonnen en op het einde van onze AiO-weg werden we weer verenigd op het eerste verdiep! Die laatste maanden op het eerste hebben we samen afgezien maar we hebben ons er ook samen doorgeworsteld, hetgeen mij een waar genoegen was! Johan J, ik heb altijd graag met $\mathrm{u}$ te doen gehad en denk nog met plezier terug aan ons congresbezoek aan Athene waarbij ook Niels een belangrijke rol gespeeld heeft. Also $\mathrm{Mu}$, Matteo, Pilar and Monica, thanks for your friendship and support! Ping, even though we are not as close anymore as we were at the start of my $\mathrm{PhD}$, you will always stay a good friend of mine! The news about your pregnancy also reached Dublin and I wish you all the best with your baby. I'm sure you only passed the best genes to your 
next generation! Verder nog dank aan Ariënne en Elke T voor de gezellige babbels en aanmoedigingen wanneer ik ze nodig had. Elke, nog veel succes met jouw laatste loodjes! Om het rijtje collega's af te sluiten wil ik natuurlijk ook Jos, Freek, Gabby, Wendy S en Loek bedanken voor alle hulp die jullie mij geboden hebben en natuurlijk ook voor het bedenken en organiseren van de 2 euro borrel! Want hierdoor, Jos, denk ik stiekem elke vrijdag om 4 uur aan Maastricht en jouw (vegetarische) hapjes.

Ook mijn dank aan Annie, Angelique en mogelijk ook Piet, oftewel, Sandy, Sander en mogelijk ook Uriell voor de geweldige tijd die we samen op de gezelligste kamer van de vakgroep hebben doorgebracht! We voelden elkaar goed aan, wisten perfect wanneer iemand behoefte had aan een babbeltje, een grapje of gewoon stilte. Het was prettig een kamer met jullie te mogen delen. Geert, hoewel ik het er in het begin moeilijk mee had dat jij op mijn plekje zou komen te zitten, weet ik nu dat je een waardig opvolger bent. Sandy en Sander, liefste paranimfjes, ik heb het jullie niet gemakkelijk gemaakt door naar Dublin te verhuizen, maar vind het echt geweldig wat jullie allemaal voor mij hebben gedaan en kan me dan ook geen betere paranimfen bedenken! Merci daarvoor!

Naast de mensen uit Maastricht wil ik natuurlijk ook de volledige brassband Panta Rhei bedanken voor de zo noodzakelijke tussentijdse ontspanning. In het bijzonder wil ik Suzy, Tomas, Wouter en Kristof bedanken om steeds klaar te staan voor mij. Ook in de brassband van Smeermaas heb ik me erg vaak erg goed geamuseerd! Natuurlijk mag ik Sylvie en Jonas niet vergeten! Sylvie, ik ben blij dat we indertijd aan het babbelen geslagen zijn. We hebben er een mooie vriendschap aan over gehouden! Jonas, wat had ik zonder u moeten beginnen? Niet alleen kennen we elkaar al behoorlijk lang en goed, jij was mijn trouwe mac-helpdesk, ook al was dat niet altijd even gemakkelijk.

Rest mij nog mijn familie te bedanken. Pa, nu is het dan zover, het proefschrift is af, de verdediging komt eraan en nu zijt ge der niet meer bij om als fiere pa naast mij te staan. We hebben hier allebei lang naar uit gekeken en ik vind het dan ook heel spijtig dat ge me net niet hebt kunnen zien 'finishen' en dat terwijl ik zoveel aan u te danken heb. "Pin houwe" zit nog in mijn geheugen gegrift en met name de laatste weken heb ik daar vaak aan terug gedacht. Ook de uitspraak "geit het neet dan bokt het mer" heb ik vaak genoeg gehoord. Wel, samen met ons ma, Suzy, Francis en Goele bokken we ons erdoor!

Ma, ik heb altijd enorm veel steun van u gehad op alle mogelijke manieren en zou het daarzonder nooit zover geschopt hebben! Francis, van stickertjes tot pep-talk, gij, Goele, Yannickske en sinds kort ook Indra'ke stonden altijd klaar voor mij! Vooral in de laatste weken zou ik het zonder uw hulp, Frens, allemaal niet klaargespeeld hebben! Tot slot Suzy, mijn grote zus en vriendin, ik ben blij dat we die 2 termen altijd zo goed hebben kunnen combineren! 



\section{List of publications}




\section{Full papers}

- Mandy Claessens, Wim HM Saris, Freek G Bouwman, Chris TA Evelo, Gabby BJ Hul, Ellen E Blaak, Edwin CM Mariman. Differential valine metabolism in adipose tissue of low and high fat-oxidizing obese subjects. Proteomics - Clinical Applications, 2007 (in press)

- Mandy Claessens, Wim Calame, André D Siemensma, Marleen A van Baak and Wim HM Saris. The effect of different protein hydrolysate/carbohydrate mixtures on postprandial glucagon and insulin responses in healthy subjects. European Journal of Clinical Nutrition, 2007 (in press)

- Mandy Claessens, Wim Calame, André D Siemensma, Wim HM Saris and Marleen A van Baak (2007). The thermogenic and metabolic effect of protein hydrolysate with or without a carbohydrate load in healthy male subjects. Metabolism 56(8): 1051-1059, 2007

- Mandy Claessens, Wim HM Saris and Marleen A van Baak. Glucagon and insulin responses after ingestion of different amouts of intact and hydrolyzed proteins. British Journal of Nutrition, 2007 (in press).

- Mandy Claessens, Marleen A van Baak, Sandy Monsheimer and Wim HM Saris. A protein- versus carbohydrate-enriched ad libitum low-fat diet improves weight control and cardiovascular risk factors in overweight and obese subjects after weight loss. Submitted.

- Mandy Claessens, Wim HM Saris, Sandy Monsheimer and Marleen A van Baak. The influence of habitual diet on responses to a high-protein meal. Submitted.

\footnotetext{
Abstract

- M Claessens, W Calame, AD Siemensma and WHM Saris. The effect of protein hydrolysates on satiety-related plasma hormones in lean subjects. Presented at European Congress on Obesity 2005 in Prague

- M Claessens, MA van Baak, S Monsheimer, WHM Saris. The effect of a longterm high-protein or high-carbohydrate ad libitum diet on weight maintenance, hormonal, glucose and lipid profiles. Presented at European Congress on Obesity 2007 in Budapest
}

\section{Oral presentations}

- M. Claessens, W. Calame, A. Siemensma, W. Saris, M. Van Baak. The thermogenic, hormonal and metabolic effect of protein hydrolysate with or without a carbohydrate load in healthy male subjects. Presented at European Congress on Obesity 2007 in Budapest 


\section{Curriculum Vitae}




\section{Curriculum Vitae}

Mandy Claessens was born on January $17^{\text {th }} 1979$ in Bilzen, Belgium. She completed secondary school at Koninklijk Atheneum Maasmechelen in Maasmechelen in 1997. From 1997 until 2001 she studied Health Sciences with a specialisation in Biological Health Sciences at Maastricht University. Her internship was spent at the University of Kuopio, Finland where she studied the effect of the Pro12Ala polymorphism in the PPARgamma2 gene on the quantitative mRNA expression of PPAR $\gamma 2$ and $\gamma$ total. She graduated in 2001 and started a master degree in Molecular Biotechnology, specialisation in Molecular Medical Biotechnology at Ghent University, Belgium where she graduated in 2002. From April 2003 until March 2007 she was appointed as a PhDstudent at the department of Human Biology, Maastricht University. The research performed during her $\mathrm{PhD}$, funded by Kerry Bio-Science, is described in the present thesis. Since May 2007, she is working at the Nutrigenomics Research Group (School of Public Health and Population Science) at the University College Dublin, Ireland where she works on a project on obesity-induced diabetes. 